\title{
(9) SINTEF
}

\section{Rapport}

\section{Forebyggende og helsefremmende arbeid (folkehelsearbeid) blant sykepleiere i helse- og omsorgstjenesten}

Kompetanse, prioritering og rammebetingelser

\section{Forfattere}

Line Melby

Roland Mandal

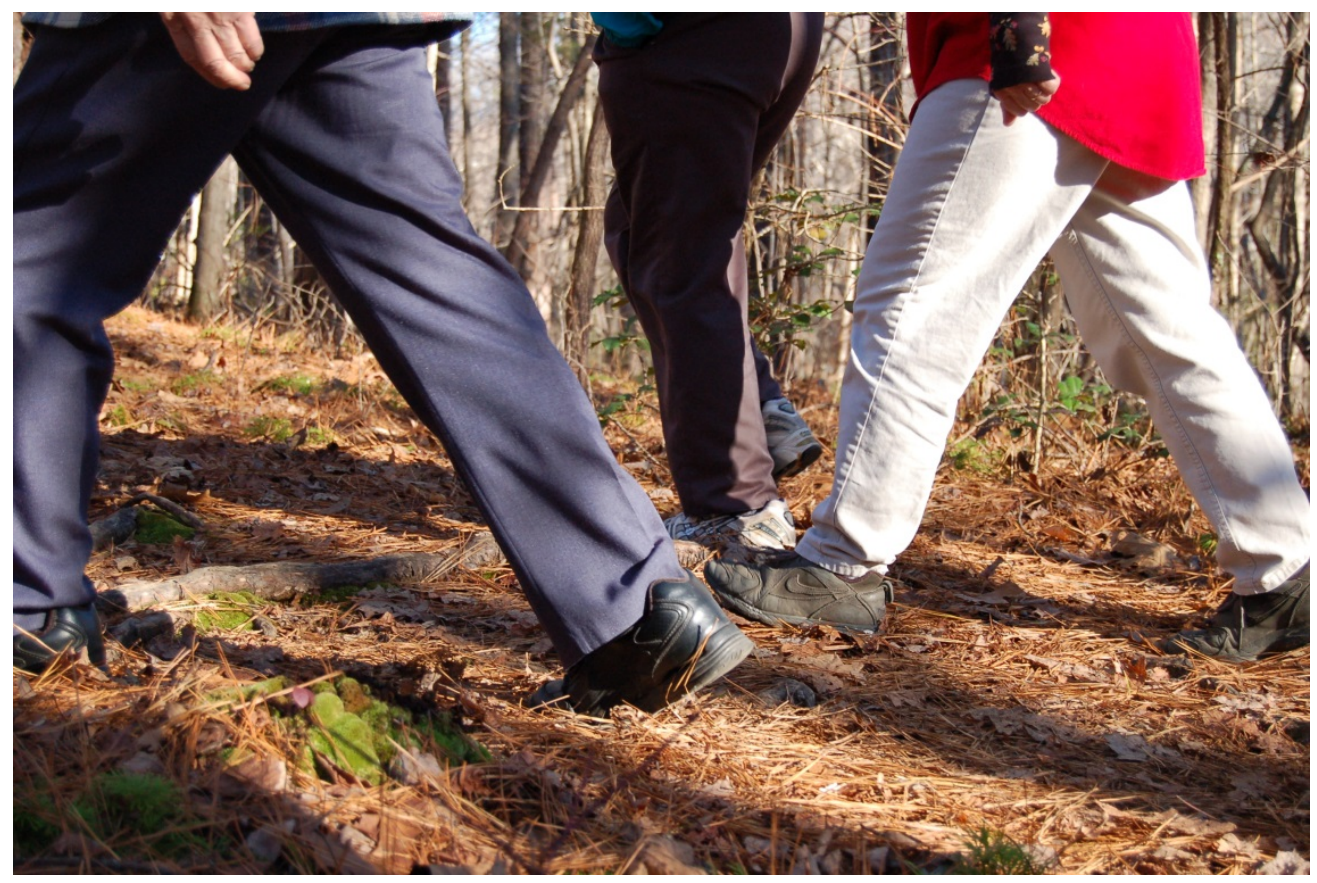


(9) SINTEF 
SINTEF Teknologi og samfunn

Postadresse:

Postboks 4760 Sluppen

7465 Trondheim

Sentralbord: 73593000

Telefaks:

ts@sintef.no

www.sintef.no

Foretaksregister:

NO 948007029 MVA

EMNEORD:

Folkehelse

Helsefremmende

Forebyggende

Sykepleie

Kompetanse

Rammebetingelser

\section{Rapport}

\section{Forebyggende og helsefremmende arbeid (folkehelsearbeid) blant sykepleiere i helse- og omsorgstjenesten}

VERSJON

1.0

FORFATTERE

Line Melby

Roland Mandal

OPPDRAGSGIVER

Norsk sykepleierforbund

PROSJEKTNR

102010334
DATO

2015-09-21
OPPDRAGSGIVERS REF.

Astrid Grydeland Ersvik

ANTALL SIDER OG VEDLEGG:

$75+$ vedlegg

SAMMENDRAG: I denne rapporten ser vi nærmere på forebyggende og helsefremmende arbeid blant sykepleiere i Norge. Basert på en spørreunders $\emptyset$ kelse og kvalitative intervjuer, begge gjennomført blant sykepleiere innenfor ulike deler av helse- og omsorgstjenestene, finner vi at det er potensial for å jobbe videre med å integrere folkehelsearbeid $\mathrm{i}$ helsetjenestene. De viktigste funnene i studien oppsummeres slik:

- Mens folkehelsearbeid oppleves å være høyere på agendaen enn tidligere, er det fortsatt et behov for å konkretisere forebyggende og helsefremmende arbeid som begreper.

- $\quad$ Sykepleiere jobber hovedsakelig sekundær- og tertiærforebyggende, mindre primærforebyggende. Unntaket er helsestasjon og skolehelsetjenesten som arbeider med primærforebygging.

- $\quad$ "Tradisjonelle" folkehelsetema, som fysisk aktivitet, hvile og $\varsigma \varnothing \vee n$, samt kosthold og ernæring, dominerer i oppfølgingen av pasientene.

- Mens egen kunnskap generelt sett vurderes som god, har mange sykepleiere behov for større flerkulturell kompetanse.

- $\quad$ Arbeidsplassen representerer en viktig læringsarena for folkehelsearbeidet.

- God dialog med pasientene er en forutsetning for å jobbe helsefremmende og forebyggende.

- $\quad$ Nettverket rundt pasientene er en av de viktigste "medspillerne" i det forebyggende og helsefremmende arbeidet.

- $\quad$ Folkehelseinnsatsen varierer med tjenestetype; type helsetjeneste ser ut til fungere som et viktig rammevilkår for hvordan folkehelsearbeid prioriteres og følges opp.

- Mange sykepleiere mener at det er for store forventninger til hva de skal bidra med på folkehelseområdet, i forhold til de rammebetingelsene de har på arbeidsplassen.

UTARBEIDET AV

Line Melby, forsker

\section{KONTROLLERT AV}

Marian Ådnanes, forskningsleder

GODKJENT AV

Randi Eidsmo Reinertsen, forskningssjef

RAPPORTNR

ISBN

SINTEF A27128
978-82-14-05972-4
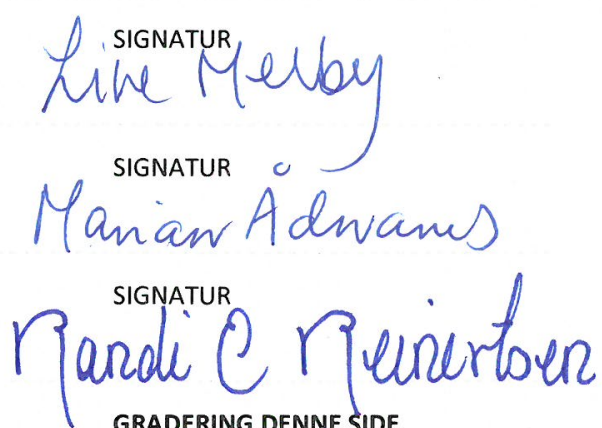

Åpen 


\section{(Q) SINTEF}

\section{Historikk}

VERSJON

1.0

DATO VERSJONSBESKRIVELSE

2015-09-21 Endelig versjon 


\section{Innholdsfortegnelse}

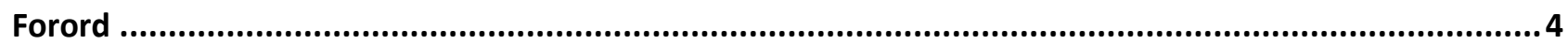

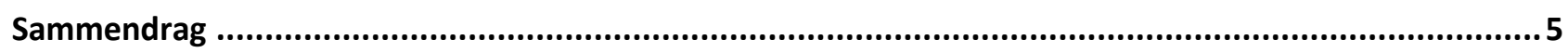

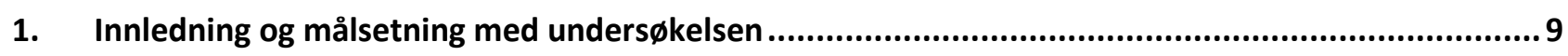

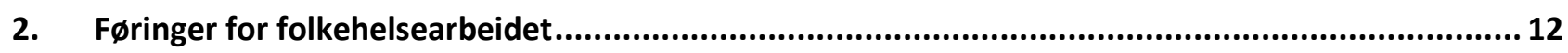

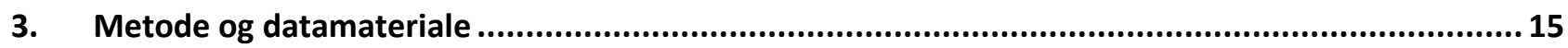

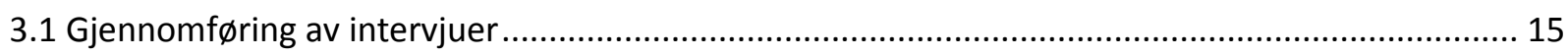

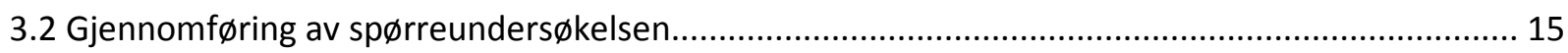

3.2.1 Kjennetegn ved sykepleierne i utvalget ................................................................... 18

4. Resultater fra spørreunders $\varnothing$ kelsen og intervjuene ..............................................................2 24

4.1 Kunnskap og erfaringer med helsefremmende og forebyggende arbeid ....................................... 24

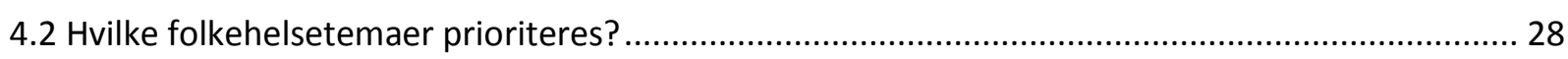

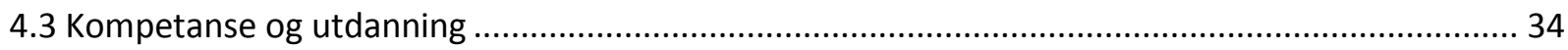

4.4 Innsats på folkehelsefeltet - tiltak og forebygging .................................................................. 37

4.5 Rammebetingelser for å jobbe forebyggende og helsefremmende ................................................ 44

4.6 Arbeidstidsordning som rammebetingelse for folkehelsearbeidet? .............................................. 47

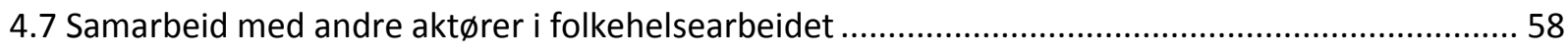

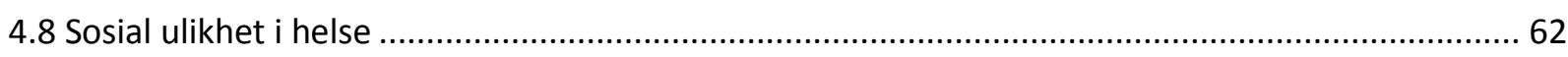

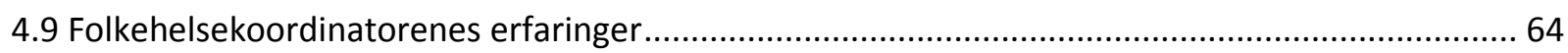

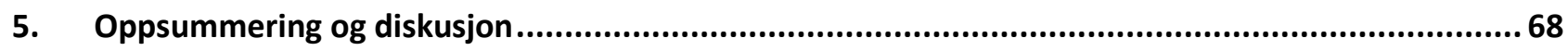

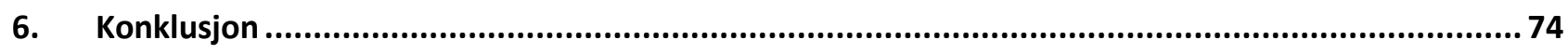

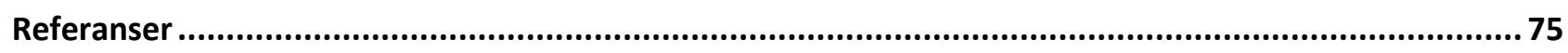

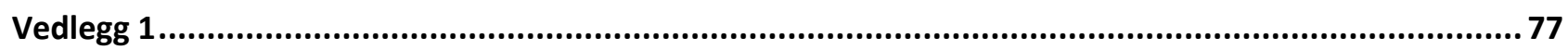




\section{(9) SINTEF}

\section{Forord}

Formålet med undersøkelsen som presenteres i denne rapporten var å innhente kunnskap om sykepleieres kompetanse, erfaringer og oppfatninger om rammebetingelsene for å drive med folkehelsearbeid. Folkehelse og folkehelsearbeid har fått mye oppmerksomhet de senere årene, og ble særlig satt på dagsordenen med innføring av Folkehelseloven 1.1.2012. Sykepleiere har mye å bidra med i folkehelsearbeidet, og vi håper rapporten kan gi nyttig kunnskap til Norsk Sykepleierforbunds (NSF) videre arbeid med å styrke folkehelseinnsatsen blant sykepleiere, og i innsatsen med å styrke rammebetingelsene for folkehelsearbeidet.

Rapporten er skrevet på oppdrag av NSF. Vi vil takke Astrid Grydeland Ersvik og referansegruppen i NSF, som ga innspill I forbindelse med utformingen av spørreskjema samt til ulike deler av rapporten. Og ikke minst $\emptyset$ nsker vi å takke sykepleierne som har stilt opp som informanter i studien, og som har svart på spørreskjemaet.

I SINTEF er det Line Melby og Roland Mandal som har gjennomført undersøkelsen og skrevet rapporten. Forskningsleder og kollega Marian Ådnanes har kvalitetssikret arbeidet.

Trondheim, 21. september 2015

Line Melby

Forsker og prosjektleder 


\section{Sammendrag}

På oppdrag fra Norsk Sykepleierforbund (NSF) har SINTEF gjennomført en undersøkelse der målet har vært å belyse sykepleieres kompetanse og erfaringer når det gjelder helsefremmende og forebyggende arbeid (folkehelsearbeid). Vi har vært spesielt opptatt av å kartlegge hvordan rammebetingelser på ulike plan innvirker på mulighetene til å jobbe på denne måten. Prosjektperioden har vart fra april til september 2015, og data har blitt samlet inn gjennom en kombinasjon av spørreundersøkelse og kvalitative intervjuer. Spørreundersøkelsen ble besvart av 2039 sykepleiere innenfor ulike deler av helse- og omsorgstjenesten, noe som resulterte i en svarprosent på 26,5. Noen av temaene som ble belyst i spørreskjemaet var kompetanse, erfaring, samarbeid, ansvarsdeling, organisering og grad av ledelsesforankring. For å innhente dybdekunnskap om sykepleieres erfaringer og oppfatninger med folkehelsearbeid, ble det i tillegg gjennomført 22 kvalitative intervjuer. Informantene ble valgt ut strategisk, for å sikre representasjon fra ulike deler av helse- og omsorgssektoren. De viktigste resultatene fra unders $\varnothing$ kelsen kan oppsummeres slik:

\section{Folkehelsearbeidet er høyere på agendaen enn tidligere, men det er et behov for å konkretisere forebyggende og helsefremmende arbeid som begreper}

En del utøvende sykepleiere synes helsefremmende og forebyggende helsearbeid er litt "ulne" begreper. Respondentene i spørreundersøkelsen synes videre det er vanskelig å si at de jobber ut i fra slike perspektiver. Funnene fra intervjuene tyder likevel på at mange i praksis anvender disse perspektivene. Alt i alt gir resultatene grunnlag for å hevde at det er behov for å øke kunnskapen og forståelsen rundt disse begrepene, og ikke minst hvordan de kan integreres og utøves innenfor ulike delene av helse- og omsorgstjenesten.

\section{De "tradisjonelle" folkehelsetemaene dominerer}

Bevegelse og fysisk aktivitet, hvile og $\varsigma \varnothing \mathrm{vn}$, samt kosthold og ernæring, er de tre temaene som prioriteres mest som en del av den oppfølgingen og dialogen sykepleierne har med sine pasienter. Samtidig finner vi at temaer som familie, venner og sosialt nettverk, trivsel og sosial mestring, også prioriteres i vesentlig grad. Som en del av pasientoppfølgingen er det mindre vanlig å bruke tid på livsstil og livsstilsendring, alkohol- og tobakksbruk, økonomi, arbeid og utdanning.

\section{Tertiær- og sekundærforebygging er mer vanlig enn primærforebygging}

Tertiærforebygging (å minske følger for livskvalitet av sykdom og funksjonsnedsettelse) er den formen for forebygging som er mest vanlig å utøve, tett fulgt av sekundærforebygging (hindre tilbakefall eller forverring av sykdom og skade). En langt lavere andel av sykepleierne i utvalget oppgir at de jobber primærforebyggende (forhindre at skade og sykdom i det hele tatt oppstår). Resultatene indikerer at det er et potensial for å styrke den forebyggende og universelle innsatsen innenfor en del tjenester. Samtidig må det tas høyde for at tjenestene er ulikt innrettet og har ulike formål og målgrupper. Det vil derfor være klare begrensninger for hvor universelt og primærforebyggende man kan jobbe innenfor en del tjenester.

\section{Det er mest vanlig å anvende indikative tiltak}

Hva slags typer tiltak anvendes hyppigst? Studien viser at det er mer vanlig å jobbe med tiltak som retter seg mot avgrensede grupper med kjent risiko (indikative tiltak), enn tiltak som retter seg mot alle (universelle tiltak). Mellom disse to finner vi de såkalte selektive tiltakene, som retter seg mot grupper som er i risikosonen når det gjelder helsemessige problemer. Både når det gjelder tiltak og forebygging er det med andre ord mest vanlig å jobbe "avgrenset", fremfor å ha en åpen og universell tilnærming. Fra et 


\section{(9) SINTEF}

tjenesteperspektiv er dette imidlertid rasjonelt, i og med at mange tjenester er tydelig avgrenset, både når det gjelder formål og målgruppe (spesielt i spesialisthelsetjenesten). Helsestasjon- og skolehelsetjenesten er den tjenesten som i klart størst grad jobber universelt og forebyggende. Samtidig fremkommer det at dette er en tjeneste som lider under ressursmangel, og som tidvis må nedprioritere universelle tiltak på bekostning av tiltak mot mer avgrensede grupper.

\section{Egen kunnskap vurderes generelt sett som god, men mange etterlyser større flerkulturell kompetanse}

Sykepleierne i studien mener generelt sett at de har god kunnskap om folkehelsearbeid. På ett punkt etterlyses imidlertid mer kompetanse blant et flertall av respondentene; nærmere bestemt flerkulturell kompetanse, i møte med pasienter fra andre kulturer. Når vi vet at folkehelseutfordringene er spesielt store i deler av innvandrerbefolkningen, er dette et klart uttrykk for at folkehelse og innvandrerhelse er områder som må prioriteres og ses i sammenheng i helsetjenesten.

\section{Arbeidsplassen er en viktig læringsarena for folkehelsearbeid}

Under halvparten av sykepleierne som deltok i spørreundersøkelsen svarte de lærte mye om helsefremmende og forebyggende arbeid gjennom sykepleierutdanningen. En stor andel ønsker seg flere kurs og mer opplæring knyttet til folkehelsearbeid på arbeidsplassen. Over halvparten av respondentene oppgir at det meste de har lært om forebyggende og helsefremmende arbeid, har de lært gjennom sitt eget arbeid. Funnene tyder på at det bør skje en styrking av folkehelsearbeid $i$ utdanningene. Samtidig er det sannsynlig at arbeidsplassen fortsatt vil representere en unik - og kanskje den viktigste - læringsarenaen. Forankring på ledernivå vil imidlertid være en viktig forutsetning for at arbeidsplassen skal fungere som en slik læringsarena.

\section{God dialog med pasientene - en forutsetning for å jobbe helsefremmende og forebyggende}

Over 80 prosent av sykepleierne som har svart på spørreskjemaet mener at det er en viktig del av deres jobb å veilede pasientene om hvordan de kan leve mer helsevennlige liv. For å få til dette, er det viktig å ha en god dialog med pasientene, svarer om lag tre fjerdedeler av respondentene. Viktigheten av en ressursfokusert tilnærming til pasientene, heller enn en sykdomsfokusert tilnærming, understrekes også av følgende funn; 63 prosent av sykepleierne er av den klare oppfatning at det ofte er vel så viktig å rette oppmerksomheten mot den enkeltes ressurser, sosiale situasjon og livsstil, som sykdommen og den medisinske diagnosen.

\section{Nettverket rundt pasienten er den "aktøren" det er mest vanlig å samarbeide med}

Folkehelsearbeid krever en tverrfaglig tilnærming, der mange aktører må samarbeide. I studien finner vi at nettverk rundt pasienten (pårørende og venner), lege i spesialisthelsetjenesten, fysio-/ergoterapitjeneste og sykepleiere i andre enheter/avdelinger er de aktørene det samarbeides mest med blant sykepleierne i utvalget. Bedriftshelsetjeneste, lokale utdanningsinstitusjoner, private rehabiliteringsinstitusjoner og arbeidsgivere er det mindre vanlig å ha kontakt med. Dessuten oppgir kun tre prosent at de samarbeider svært ofte med de kommunale frisklivssentralene (ti prosent svarer "ganske ofte"). Resultatene viser med andre ord at det er mest vanlig for sykepleierne å samarbeide med andre aktører innenfor helsesektoren. Dette er et viktig funn, når vi vet at mye av folkehelsearbeidet i samfunnet foregår utenfor helsesektoren. Når det gjelder sykepleiernes vurderinger av hvem de mener de trenger å samarbeide mer med dersom de skal få til å jobbe enda bedre på det forebyggende og helsefremmende området, så peker følgende fire 


\section{(9) SINTEF}

aktører seg ut; dietetiker/ernæringsfysiolog, fastleger, sykepleiere i andre enheter/avdelinger og nettverket rundt pasienten.

\section{Folkehelseperspektivet som tema på arbeidsplassen}

Rammebetingelsene for å drive folkehelsearbeid bestemmes både nasjonalt, lokalt i kommunen og på den enkeltes arbeidsplass. I rapporten har vi fokusert mest på rammebetingelsene på arbeidsplassen. I spørreskjemaet har respondentene blant annet blitt spurt om hvorvidt deres ledelse har kommunisert tydelig at de skal jobbe helsefremmende og forebyggende. I overkant av 40 prosent er av en slik oppfatning. Videre svarer om lag 45 prosent at helsefremmende og forebyggende arbeid er tema som ofte diskuteres på arbeidsplassen. En like stor andel er av den oppfatning at de har organisert tjenestene/ tilbudet på en måte som legger til rette for å jobbe forebyggende og helsefremmende. Andelen som opplever at deres kompetanse på helsefremmende og forebyggende innsats utnyttes på en god måte, ligger noe lavere (42 prosent). Alt i alt viser resultatene at det er et potensial for å styrke fokuset på helsefremmende og forebyggende arbeid $\mathrm{i}$ ulike deler av helse- og omsorgstjenesten. Unntaket fra dette ser ut til å være helsestasjons- og skolehelsetjenesten, som skårer svært høyt på alle våre spørsmål knyttet til mulighetene til å anvende forebyggende og helsefremmende metoder i det daglige. Dette er også som forventet.

\section{Folkehelseinnsatsen varierer med tjenestetype}

Tjenestetype kan betraktes som et rammevilkår, som legger noen føringer for mulighetene til å jobbe ut fra et folkehelseperspektiv. Med tjenestetype tenker vi her på hvilken del av helse- og omsorgssektoren man jobber innenfor. Helsestasjon/skolehelsetjenesten skiller seg positivt ut, gjennom å yte et tilbud innenfor alle de folkehelseområdene som vi har kartlagt i spørreunders $\varnothing$ kelsen. Videre finner vi betydelige forskjeller når det gjelder innslaget av helsefremmende og forebyggende arbeid blant sykepleiere som jobber dagtid versus turnus. Forankring hos ledelsen, og det å ha folkehelsearbeid som et tema i møter, er eksempelvis langt vanligere på arbeidsplasser der en jobber dagtid. Sykepleiere som jobber dagtid jobber ofte $\mathrm{i}$ poliklinikker, og det er naturlig å tenke seg at det er større rom for helsefremmende og forebyggende arbeid der enn på en sengepost, der arbeidsoppgavene er mindre forutsigbare. Det å se tjenestetype i sammenheng med arbeidstidsordning er med andre ord relevant, når rammevilkårene for folkehelsearbeid skal vurderes.

\section{Mange sykepleiere opplever at det er for store forventninger knyttet til deres bidrag i folkehelsearbeidet}

Nær halvparten av utvalget er helt eller delvis enig $i$ at det stilles for store forventninger til hva de kan bidra med innenfor helsefremmende og forebyggende arbeid. Videre finner vi at det er mer vanlig å mene dette blant ledere enn blant sykepleiere som jobber klinisk. Dette er et interessant funn, når vi vet at lederne, $\mathrm{i}$ større grad enn den "jevne sykepleier", har en plassering i organisasjonen som gjør dem i stand til å se de samlede mulighetene og barrierene for å jobbe på denne måten. En mulig forklaring kan være at lederne, gjennom å være tettere på enhetens $\varnothing$ konomiske og ressursmessige situasjon, i enda st $\varnothing$ rre grad kjenner på gapet mellom det som forventes av enheten og hva de mener er mulig å få til, med de ressurser og budsjetter som er til rådighet. 


\section{(2) SINTEF}

\section{Sosial ulikhet $i$ helse er en utfordring sykepleierne kjenner på i det daglige}

Over 60 prosent av sykepleierne mener at sosial ulikhet i helse - i stor eller ganske stor grad - er en utfordring i deres pasientgruppe. Rundt 40-45 prosent mener at de, gjennom sin pasientoppfølging, har mulighet til å redusere sosial ulikhet i helse, sosiale ulikheter i helseatferd samt sosiale ulikheter i bruken av helsetjenester. Folkehelse er nært knyttet til sosiale ulikheter i helse, og resultatet bekrefter slik sett sykepleiernes sentrale rolle innenfor folkehelsearbeidet. 


\section{Innledning og målsetning med undersøkelsen}

Norsk Sykepleierforbund (NSF) ønsket å få gjennomført en undersøkelse blant sykepleiere som belyser deres kompetanse, erfaringer og opplevelser av rammebetingelser når det gjelder helsefremmende og forebyggende arbeid (folkehelsearbeid) i sitt daglige arbeid. SINTEF Teknologi og samfunn, Avdeling Helse har gjennomført undersøkelsen på oppdrag fra NSF. Prosjektperioden har vart fra april til september 2015.

Folkehelsearbeid har fått $\varnothing \mathrm{kt}$ oppmerksomhet de seneste årene, og sykepleierne representerer en viktig yrkesgruppe i dette arbeidet. Det har imidlertid blitt fremhevet at det trengs en tydeligere retning for sykepleiernes rolle $\mathrm{i}$ folkehelsearbeidet, og en grundigere vurdering av hvordan en bedre kan utnytte sykepleiernes erfaringer og kunnskap i utøvelsen av folkehelsearbeidet. Målet med denne unders $\emptyset$ kelsen har vært å fremskaffe et statusbilde og et kunnskapsgrunnlag når det gjelder folkehelsearbeid blant sykepleiere, slik at det bedre kan legges til rette for å bruke sykepleiernes kompetanse på folkehelsefeltet, både innenfor kommune- og spesialisthelsetjenesten. Rapporten belyser følgende hovedtemaer:

- Sykepleieres kompetanse og innsats på folkehelsefeltet.

- Sykepleieres oppfatninger om, og erfaringer med folkehelsearbeid.

- Sykepleieres bevissthet og prioritering av folkehelsearbeid i det daglige arbeidet.

- Rammebetingelser for folkehelsearbeidet innenfor helse- og omsorgstjenesten.

Basert på disse føringene for prosjektet valgte SINTEF å utforme følgende hovedproblemstilling for prosjektet:

- Hvilken kompetanse og kunnskap har sykepleiere i ulike tjenester om helsefremmende og forebyggende arbeid, og hvordan opplever de at rammebetingelsene er med tanke på å kunne anvende slike metoder og tiltak overfor sine pasienter?

Med kompetanse mener vi i denne rapporten de samlede kunnskaper, ferdigheter, evner og holdninger som gjør det mulig å utføre aktuelle funksjoner og oppgaver i tråd med definerte krav og mål (Lai, 2004: 48). Kompetanse forstått på denne måten kan også sies å omfatte sykepleiernes oppfatninger om folkehelsearbeid. Innsats på folkehelsefeltet, samt erfaringer med folkehelsearbeid henger nært sammen, og vi forstår dette som det praktiske uttrykket for å ha og utøve kompetanse. I undersøkelsen har vi vurdert det som viktig å fange opp både sykepleieres kunnskap om - og holdninger til - folkehelse, samt hvordan de konkret bruker og utøver denne kunnskapen. Videre har vi forsøkt å svare på i hvilken grad sykepleierne opplever å være trygge i sin profesjon innenfor fagområdet folkehelse. I rapporten har vi samlet disse elementene under overskriften "Kunnskap og erfaringer med helsefremmende og forebyggende arbeid" (del 4.1) (individnivå).

Når det gjelder bevissthet og prioritering rundt folkehelsearbeidet, ser vi dette $\mathrm{i}$ sammenheng med rammebetingelsene for at sykepleiere kan drive med folkehelsearbeid $\mathrm{i}$ helsetjenesten. Rammebetingelsene for å drive med folkehelsearbeid handler om organisatoriske rammer og ressurser, lovgivning og retningslinjer, samt hvem sykepleiere kan samarbeide med i folkehelsespørsmål. Kunnskap

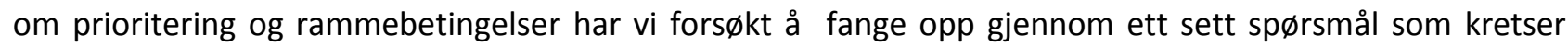
rundt temaer som bemanning, tid til helsefremming og forebygging (og ikke bare behandling), ledelse samt 


\section{(9) SINTEF}

oppmerksomhet om folkehelsearbeid på arbeidsplassen. Disse temaene er presentert i ulike delkapitler i kapittel 4.

Reduksjon i sosial ulikhet er et sentralt mål for folkehelsearbeidet (Helse- og omsorgsdepartementet, 2015). Med sosial ulikhet i helse mener vi relativt systematiske forskjeller i helse (fysisk som psykisk) som kan knyttes til forskjeller i befolkningen når det gjelder utdanningsnivå, yrke, inntekt, og bosted/geografi. I undersøkelsen har vi inkludert noen spørsmål om sosial ulikhet. Resulatene er presentert i 4.8 "Sosial ulikhet i helse".

Rapporten er bygget opp på følgende måte: I kapittel 2 trekker vi opp linjene for utviklingen av folkehelsearbeidet i Norge, og ser på sykepleiernes plass i dette arbeidet. Kapittel 3 tar for seg metode og gir en beskrivelse av datamaterialet. I kapittel 4 presenterer vi resultatene fra spørreunders $\varnothing$ kelsen og intervjuene. En sammenfatning av intervjuene med folkehelsekoordinatorene presenteres i eget avsnitt, helt sist i kapittel 4. Vi oppsummerer og drøfter funnene i kapittel 5, mens konklusjoner og noen anbefalinger for hvordan sykepleiere bør arbeide videre med folkehelsearbeid presenteres i kapittel 6 .

Datamaterialet i undersøkelsen er innhentet gjennom en spørreundersøkelse til et utvalg av NSFs medlemmer, og gjennom intervjuer med et strategisk utvalg sykepleiere. I spørreskjemaet slo vi sammen noen av hovedtemaene, slik at det har en struktur med bakgrunn, kunnskap og erfaringer med folkehelsearbeid, rammebetingelser for folkehelsearbeid og sosial ulikhet i helse. Se forøvrig kapittel 3 for

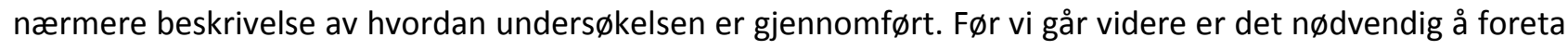
en presisering og avgrensning av de begrepene som er mest sentrale i rapporten:

Med folkehelsearbeid mener vi i denne rapporten "samfunnets totale innsats for å opprettholde, bedre og fremme befolkningens helse gjennom å svekke faktorer som medfører helserisiko, og styrke faktorer som bidrar til bedre helse". Folkehelsearbeidet omfatter både helsefremmende og forebyggende arbeid.

Helsefremmende arbeid betyr å styrke de faktorer som setter mennesket i stand til å bevare og bedre sin helse, og er kjernen i folkehelsearbeidet.

Forebyggende helsearbeid innebærer å opprettholde befolkningens helse ved å utvikle tiltak som kan føre til en reduksjon i sykdommer, skader, sosiale problemer, dødelighet og å redusere kjente risikofaktorer. Primær-, sekundær- og tertiærforebygging beskriver når i problemutviklingsprosessen tiltak settes inn, mens universelle, selektive og indikative tiltak sikter til hvilke grupper tiltakene rettes mot.

Folkehelse er et stort og omfattende begrep, som er vanskelig å avgrense. Ifølge Folkehelsemeldingen (Helse- og omsorgsdepartementet, 2015) handler folkehelsearbeid "både om å fremme livskvalitet og trivsel, gjennom deltakelse $i$ sosialt fellesskap som gir tilhørighet og opplevelse av mestring, og om å redusere risiko for sykdom, funksjonsnedsettelse, psykiske og sosiale problemer." Det virker også å være en $\emptyset$ kende tendens til å hekte "alt" som kan knyttes til befolkningens helse og velferd på folkehelsebegrepet. Ifølge Helsedirektoratet rommer folkehelsebegrepet "befolkningens helsetilstand og hvordan helsen fordeler seg i en befolkning," mens folkehelsearbeid i folkehelseloven defineres slik: "samfunnets innsats for å påvirke faktorer som direkte eller indirekte fremmer befolkningens helse og trivsel, forebygger psykisk 


\section{(9) SINTEF}

og somatisk sykdom, skade eller lidelse, eller som beskytter mot helsetrusler, samt arbeid for en jevnere fordeling av faktorer som direkte eller indirekte påvirker helsen."

Helsedirektoratet presiserer videre at folkehelsearbeid ikke omfatter kurative tjenester $\mathrm{i}$ form av diagnostikk, behandling, pleie og omsorg. Det omfatter heller ikke habilitering eller rehabilitering. ${ }^{1}$ Vi ser dermed at det foretas en avgrensning mot behandling av syke $i$ helsetjenesten. Dette er en viktig avgrensning, som er relevant for vår undersøkelse, i og med at mange av sykepleierne i utvalget jobber klinisk og pasientnært. Vil mange sykepleiere da kunne ha en annen oppfatning av folkehelsebegrepet enn det som fremgår av offentlige dokumenter og lovverk? Vi svarer ikke på dette spørsmålet her, men tar det med oss utover i rapporten. Spesielt i lys av den forståelsen som er presentert foran, der folkehelsearbeid i stor grad betraktes som den "helseinnsatsen" i samfunnet som skjer utenfor operasjonsstuer, poliklinikker, sengeposter og sykehjem, så må vi ta høyde for at sykepleiere legger ulikt innhold $\mathrm{i}$ folkehelsearbeid. Avhengig av hvilke tjenester de jobber innenfor og hvilke pasientgrupper de jobber inn mot, må vi være åpne for at sykepleiernes forståelse av folkehelsearbeid vil kunne avvike fra de offisielle definisjonene.

Vi gjør ellers oppmerksom på at vi i rapporten bruker begrepet pasient for å dekke alle tjenestemottakere i undersøkelsen (barn, ungdom, foreldre, brukere, klienter og borgere).

\footnotetext{
${ }^{1}$ https://helsedirektoratet.no/folkehelse/folkehelsearbeid-i-kommunen/lokalt-folkehelsearbeid (lesedato: 1.6.15)
} 


\section{Føringer for folkehelsearbeidet}

Folkehelsearbeidet i Norge reguleres av flere lover, men primært gjennom Lov om folkehelsearbeid (folkehelseloven). I tillegg foreligger det en rekke offentlige dokumenter som gir føringer for arbeidet som generelt gjøres i kommuner og fylkeskommuner, og mer spesifikt i helse- og omsorgssektoren. Folkehelseloven har som formål "å bidra til en samfunnsutvikling som fremmer folkehelse, herunder utjevner sosiale helseforskjeller. Folkehelsearbeidet skal fremme befolkningens helse, trivsel, gode sosiale og miljømessige forhold og bidra til å forebygge psykisk og somatisk sykdom, skade og lidelse" (Helse- og omsorgsdepartementet, 2011a). Myndighetenes overordnede mål for folkehelsearbeidet er formulert slik:

- Norge skal være blant de tre landene i verden med høyest levealder

- Befolkningen skal oppleve flere leveår med god helse og trivsel og reduserte sosiale helseforskjeller

- Vi skal skape et samfunn som fremmer helse i hele befolkningen (Helse- og omsorgsdepartementet, 2013)

Videre bygger folkehelseloven på fem prinsipper som skal være førende for et systematisk og langsiktig folkehelsearbeid:

- Helse i alt vi gjør

- Utjevning

- Føre var

- Medvirkning

- Bærekraftig utvikling

Dette er ambisiøse mål og viktige prinsipper. Utfordringen er naturligvis å omsette dem i praksis. Kommunene har i så måte et stort ansvar for folkehelsearbeidet og er den mest sentrale aktøren i et slikt arbeid (Riksrevisjonen, 2015). I følge folkehelseloven $\S 4$ skal kommunen "fremme befolkningens helse, trivsel, gode sosiale og miljømessige forhold og bidra til å forebygge psykisk og somatisk sykdom, skade eller lidelse, bidra til utjevning av sosiale helseforskjeller og bidra til å beskytte befolkningen mot faktorer som kan ha negativ innvirkning på helsen." Også i Lov om kommunale helse- og omsorgstjenester (helse- og omsorgstjenesteloven) trekkes helsefremming og forebygging fram. Det heter i § 3-3 at "Kommunen skal ved ytelse av helse- og omsorgstjenester fremme helse og søke å forebygge sykdom, skade og sosiale problemer. Dette skal blant annet skje ved opplysning, råd og veiledning" (Helse- og omsorgsdepartementet, 2011b). Lokal utvikling, planlegging, forvaltning og tjenesteyting i kommunene må således gjennomføres med disse målene i mente.

Videre er det formulert krav til kommunene om å kartlegge folkehelsen blant kommunens befolkning. I folkehelseloven $\S 5$ heter det at "Kommunen skal ha nødvendig oversikt over helsetilstanden i befolkningen og de positive og negative faktorer som kan virke inn på denne". Og "Oversikten skal være skriftlig og identifisere folkehelseutfordringene i kommunen, herunder vurdere konsekvenser og årsaksforhold. Kommunen skal særlig være oppmerksom på trekk ved utviklingen som kan skape eller opprettholde sosiale eller helsemessige problemer eller sosiale helseforskjeller." I Riksrevisjonens unders $\emptyset$ kelse (data innhentet i 2014) fremkom det at 24 prosent av kommunene hadde utarbeidet en oversikt over helsetilstanden og påvirkningsfaktorer, mens 59 prosent oppga at de hadde delvis oversikt og at oversikten var under 


\section{(9) SINTEF}

utarbeidelse. 16 prosent av kommunene oppga at de ikke hadde påbegynt oversiktsarbeidet (Riksrevisjonen, 2015). Statens helsetilsyn har gjennom landsomfattende tilsyn også unders $\emptyset$ kt hvor langt kommunene har kommet $\mathrm{i}$ kartleggingen av helsetilstanden $\mathrm{i}$ kommunen. Helsetilsynet fant at kommunene viet folkehelsearbeid mye oppmerksomhet, men det var stor variasjon $\mathrm{i}$ forhold til hvor langt de hadde kommet i kartleggingen (Helsetilsynet, 2015). Dette samsvarer godt med det Riksrevisjonen fant.

Ser vi på utfordringer knyttet til kartleggingsarbeidet, peker Helsetilsynet på at manglende styring og tilrettelegging, dårlig forankring i kommuneledelsen, samt manglende tverrsektoriell forankring var faktorer som gjorde at arbeidet hadde kommet kort i flere kommuner (Helsetilsynet, 2015). Når det gjelder kommunenes kunnskap på de ulike folkehelseområdene, viser Riksrevisjonens rapport at særlig på området sosial ulikhet mangler det kunnskap, noe som gjør det vanskelig å få overblikk over utvikling og utfordringer på området (Riksrevisjonen, 2015). En systematisk oversikt over helsetilstanden og hvilke påvirkningsfaktorer som eksisterer $\mathrm{i}$ kommunen, er en forutsetning for å gi retning til det videre folkehelsearbeidet og prioritere på en hensiktsmessig måte.

I Riksrevisjonens studie (2015) har kommunene beskrevet det de oppfatter som sine største folkehelseutfordringer. De tre områdene som oppleves som mest utfordrende er psykisk helse, levekår og sosial ulikhet, samt befolkningssammensetning. Kommunene har også rapportert hva slags tiltak de har iverksatt. De fleste tiltakene som er iverksatt handler om å fremme fysisk aktivitet og etablere frilufts- og grøntområder. Deretter kommer tiltak innenfor psykisk helse og skole/utdanning. Det er altså ikke særlig godt samsvar mellom hva kommunene definerer som sine største utfordringer og hva slags tiltak som iverksettes. Denne mangelen på samsvar forklares delvis med historikk og delvis med kommunenes muligheter. Fysisk aktivitet og kosthold beskrives som klassiske levevanetemaer som lenge har inngått $\mathrm{i}$ kommunenes folkehelsearbeid. På dette området har kommunene god kompetanse, tiltakene er ikke så kostbare, og påvirkningen på sykdomsutvikling er målbar og godt dokumentert. Riksrevisjonen konkluderer med at kommunene ser ut til å prioritere arbeidet med levevaner - altså tiltak på individnivå - heller enn å jobbe med strukturelle endringer.

Selv om kommunene har den mest sentrale rollen i folkehelsearbeidet, spiller også spesialisthelsetjenesten en rolle. Vi redegjør kort for den her, siden denne delen av helsetjenesten er en viktig arbeidsgiver for mange sykepleiere. Som nevnt ovenfor omfatter ikke folkehelsearbeid "offisielt" kurative tjenester. Likevel er det rom for mye forebyggende og helsefremmende arbeid innenfor spesialisthelsetjenesten. I Lov om spesialisthelsetjenester heter det da også at lovens formål særlig er å "fremme folkehelsen og å motvirke sykdom, skade, lidelse og funksjonshemning" (Helse- og omsorgsdepartementet, 1999). Helsefremmende og forebyggende innsats er aktuelt innenfor både somatikk og psykisk helsevern og rus, for eksempel kan slikt arbeid være inkludert i kvalitetsarbeid i sykehusene. Andre typer mer eksplisitt formulerte forebyggende tiltak i samarbeid med kommunen kan også forekomme, som vi skal se senere i rapporten.

Videre i denne rapporten ser vi nærmere på sykepleiernes rolle og bidrag når det gjelder å oppfylle disse målsetningene gjennom helsefremmende og forebyggende arbeid innenfor helse- og omsorgstjenestene. Sykepleiere er en stor og viktig yrkesgruppe i den norske helse- og omsorgssektoren, og de er å finne i alle deler av sektoren, fra akuttmottak og operasjonsstuer (spesialisthelsetjenesten) til mer hjemmebasert omsorg i kommunene (primærhelsetjenesten). Per 4. kvartal 2014 var det 99416 sykepleiere, 3159 


\section{(9) SINTEF}

jordmødre og 4379 helsesøstre i Norge (totalt 106 954), og årlig utdannes det cirka 3500 sykepleiere. ${ }^{2}$ । kraft av å være en stor yrkesgruppe, som befinner seg i alle deler av helse- og omsorgssektoren, er det åpenbart at sykepleiere bør ha en nøkkelrolle i folkehelsearbeidet i det norske samfunnet. I hvilken grad de faktisk gjør det er imidlertid et annet spørsmål, og ett av de spørsmålene vi retter oppmerksomheten mot i denne rapporten. Gjennom rapporten håper vi å presentere et statusbilde av sykepleieres erfaringer med folkehelsearbeid, og hva som bør gjøres for å styrke deres muligheter til å kunne jobbe mer med helsefremmende og forebyggende arbeid, innenfor alle deler av det norske helsevesenet.

${ }^{2}$ http://www.ssb.no/arbeid-og-lonn/statistikker/hesospers/aar/2015-06-12?fane=tabell\&sort=nummer\&tabell =229477 https://www.nsf.no/ikbViewer/Content/2198564/seefile (lesedato: 17.09.15) 


\section{Metode og datamateriale}

\subsection{Gjennomføring av intervjuer}

I tillegg til spørreundersøkelsen gjorde vi 22 intervjuer for å innhente dybdekunnskap om sykepleieres erfaringer og oppfatninger med folkehelsearbeid. Informantene ble strategisk utvalgt for å representere ulike deler av helse- og omsorgssektoren. NSF bisto med navn på en rekke kontaktpersoner, mens rekrutteringen ble gjort av SINTEF. Totalt ble 22 personer intervjuet, fordelt på 20 intervjuer. Informantene representerte kommunehelsetjenesten med hjemmetjeneste, sykehjem, psykisk helsearbeid (6) helsesøstre (3), spesialisthelsetjenesten med somatisk klinisk sykehus og psykisk helsevern (4), i tillegg ble folkehelsekoordinatorer fra ni kommuner intervjuet.

Tabell 1 Oversikt over informantene som deltok i intervju.

\begin{tabular}{lc}
\hline Tilhørighet & Antall \\
\hline Folkehelsekoordinatorer & 9 \\
Kommunehelsetjenesten & 9 \\
Spesialisthelsetjenesten & 4 \\
\hline
\end{tabular}

Informantene kom fra 16 kommuner der alle landsdeler er dekket. Kommunene varierte i størrelse fra små (under 5000 innbyggere) til store (Oslo). Informantene representerte tre ulike helseforetak, fra hver sin region. Vi utarbeidet to varianter av intervjuguider, til henholdsvis folkehelsekoordinatorene og ut $\varnothing v e n d e$ sykepleiere. Intervjuguiden ble brukt som støtte i intervjuene, men styrte ikke samtalen fullstendig. Det var imidlertid viktig å få alle informantene til å pense innom de samme temaene, noe de også gjorde. Intervjuguiden omhandlet hva slags konkrete erfaringer de hadde med folkehelsetiltak (type tiltak), samarbeidspartnere, oppfatninger av rammebetingelser for folkehelsearbeid og vurderinger av sykepleieres kompetanse for å jobbe folkehelserettet. I tillegg problematiserte mange av de ut $\varnothing v e n d e$ sykepleierne blant informantene begrepet "folkehelse", siden dette var et begrep de ikke vanligvis brukte for å beskrive sin arbeidsinnsats. Tre av intervjuene (med totalt fem personer) ble gjort ansikt til ansikt, mens de resterende intervjuene ble gjort per telefon. Intervjuene varte mellom 30 og 50 minutter og ble gjort opptak av. Intervjuene ble senere transkribert, foruten to som det kun ble skrevet sammendrag av.

Hovedtemaene oppdragsgiver $\varnothing$ nsket belyst strukturerte analysen av intervjuene. Alle intervjuene er gjennomgått, og sitater valgt ut for å presentere og belyse resultatene. Vi har integrert innsikt - og sitater fra intervjuene med funnene fra spørreundersøkelsen, slik at resultatene fremstår som et hele, men vist gjennom ulike data. Vi har latt informantene være anonyme der vi presenterer sitater, men har skilt mellom folkehelsekoordinator og de andre sykepleierne, gitt at disse har svært ulike roller.

\subsection{Gjennomføring av spørreunders $\varnothing$ kelsen}

Det er SINTEF som har hatt ansvaret for å utarbeide spørreskjemaet. Underveis i denne prosessen har vi hatt tett dialog med NSF, som har bidratt med nyttige avklaringer og innspill. Sentio sto for selve gjennomføringen av spørreunders $\varnothing$ kelsen, ved hjelp av det elektroniske sp $\varnothing$ rreskjemaverkt $\varnothing$ yet QuestBack. Medlemsliste for NSFs medlemmer ble oversendt direkte fra NSF til Sentio, og det ble trukket et tilfeldig utvalg sykepleiere fra denne listen. Utvalget besto av 8000 sykepleiere. 


\section{(9) SINTEF}

En viktig målsetning i denne fasen var å sile ut de sykepleierne på medlemslisten som ikke jobber klinisk (det vil si de som verken jobber i spesialisthelsetjenesten eller kommunehelsetjenesten). Dette skulle sikre at skjemaet kun ble sendt til sykepleiere som jobbet med pasienter. Dette kunne også være på ledernivå. NSF meldte tilbake at det ikke var noe problem å filtrere bort de som ikke jobber klinisk, i og med at de har informasjon om tariffavtale, bedriftskategori og stillingsbetegnelse for sine medlemmer. NSF har relativt gode data over hvor de yrkesaktive medlemmene jobber. Siden det er endringer i medlemsmassen daglig, ble medlemslisten sendt over til Sentio rett for utvalget skulle trekkes, for å sikre en mest mulig oppdatert medlemsliste. Unders $\emptyset$ kelsen ble holdt åpen i perioden 4. juni - 1. juli 2015. I denne perioden ble det sendt ut to purringer, den første 15.6, den andre 22.6. Figur 1 viser utviklingen i svarinngang i perioden undersøkelsen var åpen.

Antall svarende i løpet av perioden

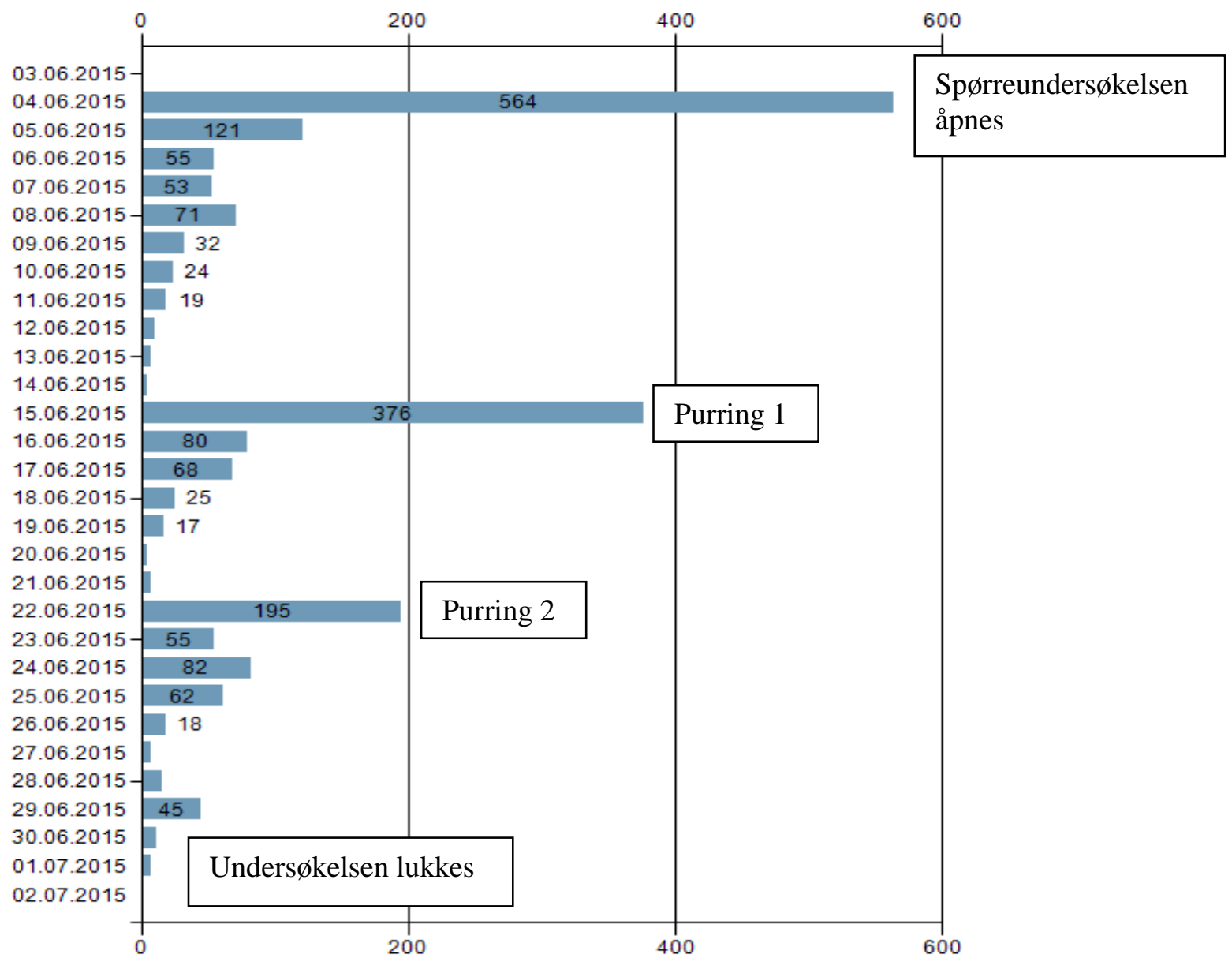

Figur 1 Svarinngang i perioden undersøkelsen var åpen (4. juni - 1. juli 2015)

7997 sykepleiere mottok til slutt spørreskjemaet. Gruppen "ikke kontaktbare" besto til slutt av 307 personer. Dette gir et justert bruttoutvalg (justert for naturlig frafall) på 7690 . Av disse var det 2039 som svarte på undersøkelsen (nettoutvalget), noe som ga en svarprosent på 26,5. Cirka én av fire sykepleiere i opprinnelig utvalg endte derfor opp med å besvare spørreskjemaet. 
Det var lenge en stor andel av utvalget som ikke mottok undersøkelsen, og som dermed ikke kunne delta (hadde statusen "ikke kontaktbar"). Dette gjaldt 1223 personer, det vil si 15 prosent av bruttoutvalget. Gitt informasjonen vi mottok om at medlemslisten skulle være oppdatert, tolket vi dette som et urimelig stort bortfall i den gruppen som hadde blitt invitert til å delta i unders $\varnothing$ kelsen. Nærmere unders $\varnothing$ kelser viste at dette handlet om tekniske problemer $\mathrm{i}$ forbindelse med utsendingen av spørreskjemaet. Siden gruppen med "ikke kontaktbare" var så stor ble det gjort noen ekstra fors øk på å sende ut spørreskjemaet spesifikt til denne gruppen, og det lyktes til slutt å få undersøkelsen ut også til disse.

Vi kan ikke utelukke at dette var en hendelse som kan ha påvirket svarprosenten noe, i og med at det førte til at en relativt stor del av utvalget fikk mye kortere tid på seg til å besvare undersøkelsen. Som en konsekvens av at denne "gruppen" mottok skjemaet først 24. juni, så måtte vi holde undersøkelsen åpen litt lenger enn planlagt. Det ble sendt en ekstra purring, kun til denne gruppen 29. juni, og hele utvalget hadde anledning til å svare til og med 1 . juli. Uansett var det bra for undersøkelsen at andelen "ikke kontaktbare" ble redusert fra 15 prosent til mer naturlige 3,8 prosent, som følge av at de tekniske utfordringene ble løst.

Vårt generelle inntrykk er at det har vært litt treg respons på undersøkelsen, noe som kommer frem i figur 1. Mange svarte samme dag som skjemaet ble sendt ut, men etter dette har det vært en ganske lav svarinngang, når vi vet at cirka 8000 medlemmer ble kontaktet i utgangspunktet. Figuren viser ellers at de to purringene (15.6 og 22.6) hadde brukbar effekt på deltakelsen. I store deler av perioden var det imidlertid svært få som svarte på undersøkelsen. Mulige årsaker til dette blir drøftet senere. Det er samtidig viktig å påpeke at en moderat svarprosent, samt en noe tung "mobilisering" underveis, kan tenkes å representere et funn i seg selv, knyttet til hvilken prioritet folkehelsearbeid i dag har blant sykepleiere innenfor ulike helsetjenester. Muligens sier det også noe om i hvilken grad folkehelsearbeid som tema er egnet til å vekke den jevne sykepleiers engasjement og interesse. Dette er spørsmål vi kommer tilbake til senere i rapporten.

Det finnes ingen fasitsvar på hva som er en høy (tilfredsstillende) eller lav (ikke tilfredsstillende) svarprosent. Tematikk, omfang av spørreskjema samt målgruppens tilgjengelighet er eksempler på faktorer som vil påvirke deltakelsen i en unders $\emptyset$ kelse. I tillegg kan svarprosenter vanskelig sammenlignes på tvers av ulike undersøkelser og utvalg. Det at vi har et relativt stort utvalg i utgangspunktet (cirka 8000 ) gjør at en svarprosent på 26,5 er mindre problematisk enn om utvalget hadde vært på 800 . Med økende utvalgsstørrelse reduseres feilmarginene i resultatene, selv om svarprosenten er den samme. Vi velger å konkludere med at en svarprosent på 26,5 i en kartleggingsundersøkelse blant sykepleiere trolig ikke er så verst. Dette er en travel yrkesgruppe med utstrakt pasientkontakt, og som innenfor arbeidstiden vil ha svært begrensede muligheter til å sette seg ned og fylle ut et elektronisk spørreskjema. Tilgangen til PC, samt muligheten til å benytte denne i arbeidstiden, vil ofte være lav. Mange må derfor bruke fritiden sin til å delta.

Den viktigste enkeltfaktoren som kan forklare at svarprosenten ikke ble høyere tror vi handler om folkehelse (forebyggende og helsefremmende arbeid) som tema, og i hvilken grad sykepleierne har erfaring med tematikken og identifiserer seg med den. Spørreskjemaet handlet utelukkende om helsefremmende og forebyggende arbeid, på et temmelig detaljert nivå, og man skal være godt inne i tematikken for å 


\section{(9) SINTEF}

oppleve det som meningsfylt å sette av 10-15 minutter til å besvare spørreskjemaet. Skjemaet inneholdt også påstander der det er en fordel å ha jobbet helsefremmende/forebyggende for å kunne ta stilling til dem. Dersom man i liten grad har brukt et folkehelseperspektiv i sitt arbeid, er dermed ikke forutsetningene for å svare på mange av spørsmålene til stede. Dette kan ha påvirket svarprosenten.

Det er en viss risiko for at vi har endt opp med et selektert utvalg. Med dette mener vi at observerbare og/eller ikke-observerbare kjennetegn ved personene i utvalget kan ha påvirket hvem som til slutt valgte å delta i unders $\varnothing$ kelsen. Det trenger med andre ord ikke være tilfeldig hvem det er blant de 7690 som valgte å svare, og dette kan skape skjevheter i resultatene, i den forstand at de blir mindre representative. Det vi drøftet tidligere, om sykepleiernes nærhet til tematikken (gjennom sitt daglige arbeid og interesser for $\varnothing v$ rig), er åpenbart en faktor som kan ha påvirket hvem som svarte. Spesielt når temaet er folkehelse, som er et diffust og "stort" tema, så vil det være en mulighet for at man rekrutterer de personene som er mest engasjert i temaet, og muligens de som har et grunnleggende positivt forhold til folkehelsearbeid. Samtidig kan det være at en del ble motivert til å delta fordi de mener at forventningene er for store med tanke på hva det er mulig å oppnå når det gjelder helsefremmende og forebyggende innsats $\mathrm{i}$ helse- og omsorgstjenestene. Kanskje har noen blitt motivert til å delta fordi de mener at dette er noe som sykepleiere ikke bør bruke tid på. Basert på temaets natur vil vi likevel anta at i den grad det har vært en seleksjonseffekt til stede, så kommer denne til uttrykk ved at sykepleierne i det endelige utvalget har mer erfaring og er mer opptatt av folkehelsearbeid enn populasjonen av sykepleiere generelt.

\subsubsection{Kjennetegn ved sykepleierne i utvalget}

$\mathrm{Vi}$ presenterer $\mathrm{i}$ det følgende en del sentrale kjennetegn ved sykepleierne som har deltatt $\mathrm{i}$ spørreundersøkelsen.

Tabell 2 Kjønn og alder blant sykepleierne i utvalget. Antall og prosent.

\begin{tabular}{rrr}
\hline Kjønn & Antall & Prosent \\
\hline$\bullet \quad$ Kvinne & 1837 & 91,3 \\
$\bullet \quad$ Mann & 176 & 8,7 \\
\hline Totalt & 2013 & 100 \\
\hline Ikke svart & 26 & \\
\hline Alder & & \\
$\bullet \quad 30$ år eller yngre & 55 & 2,7 \\
$\bullet \quad 31-40$ år & 499 & 24,5 \\
$\bullet \quad 41-50$ år & 576 & 28,3 \\
$\bullet \quad 51-60$ år & 711 & 35 \\
$\bullet \quad 61$ år eller eldre & 193 & 9,5 \\
\hline Totalt & 2034 & 100 \\
\hline Ikke svart & 5 & \\
\hline
\end{tabular}

Opplysninger om alder og kjønn er i denne undersøkelsen mest relevant som ren bakgrunnsinformasjon om respondentene. Den viktigste grunnen til dette er en antakelse om at arbeidstidsordning, samt hvilken tjeneste man jobber innenfor etc., er mer relevant for å forklare variasjoner $\mathrm{i}$ folkehelseinnsatsen enn sykepleiernes kjønn og alder. Kjønn er i tillegg veldig empirisk skjevfordelt; 8,7 prosent av sykepleierne i 


\section{(9) SINTEF}

utvalget er menn. Vi har ikke funnet noen tall som viser kjønnsfordelingen i populasjonen av sykepleiere, men vet at 15 prosent av dem som søkte opptak på sykepleierutdanningen i 2011, var menn.

Neste tabell viser innenfor hvilken del av helse- og omsorgssektoren sykepleierne i utvalget jobber. Her kunne man krysse av for flere alternativer.

Tabell 3 Hvilken del av helse- og omsorgssektoren jobber du innenfor? Antall og prosent.

\begin{tabular}{lrr}
\hline Kommunal helse- og omsorgstjeneste & Antall & Prosent \\
\hline Helsestasjon/skolehelsetjeneste & 206 & 16,6 \\
Sykehjem/omsorgsbolig/held $\varnothing$ gns omsorg & 336 & 27,1 \\
Hjemmesykepleie & 210 & 16,9 \\
Kommunalt psykisk helsevern/rus & 99 & 8 \\
Kommunal akutt døgnenhet (KAD) & 23 & 1,9 \\
Legevakt & 54 & 4,4 \\
Dagsenter (for eldre) & 12 & 1 \\
Frisklivssentral & 6 & 0,5 \\
Annet & 294 & 23,7 \\
\hline Totalt & 1240 & 100 \\
\hline Spesialisthelsetjeneste & & \\
\hline Akuttmottak/intensivavdeling/operasjonsavdeling & 399 & 34,2 \\
Sengepost & 331 & 28,4 \\
Poliklinikk & 187 & 16,1 \\
Dagtilbud & 41 & 3,5 \\
Lærings- og mestringssenter/mestringsskole & 8 & 0,7 \\
Arbeidsrettet rehabilitering & 5 & 0,4 \\
Annet & 194 & 16,7 \\
\hline Totalt & 1165 & 100 \\
\hline *Bedriftshelsetjeneste & 15 &
\end{tabular}

Vi vet at det er 2039 unike personer i utvalget. Dersom vi summerer total $\mathrm{N}$ i tabell 3 (både kommune- og spesialisthelsetjenesten), så ender vi opp med $\mathrm{N}=2$ 405. Forklaringen på dette er at en del sykepleiere jobber innenfor to eller flere tjenester, enten innenfor kommunehelsetjenesten eller spesialisthelsetjenesten. Noen kombinerer også jobbing i kommunehelsetjenesten med jobbing i spesialisthelsetjenesten.

Både innenfor kommunal helse- og omsorgstjeneste og spesialisthelsetjenesten er det tre tjenester som skiller seg ut når det gjelder antall respondenter. For kommunehelsetjenesten er det helsestasjon/skolehelsetjeneste $\quad(\mathrm{N}=206)$, sykehjem/omsorgsbolig/heldøgns omsorg $(\mathrm{N}=336)$ og hjemmesykepleie $(\mathrm{N}=210)$ som er best representert. Når det gjelder spesialisthelsetjenesten, så er det følgende tre tjenester som skiller seg ut: akuttmottak/intensivavdeling/operasjonsavdeling ( $N=399)$, sengepost $(\mathrm{N}=331)$ og poliklinikk ( $\mathrm{N}=187)$. Samlet sett står disse seks tjenestene for 75 prosent av avkrysningene. Dette er derfor de seks tjenestene innenfor henholdsvis kommunehelsetjenesten og 


\section{(9) SINTEF}

spesialisthelsetjenesten som vi kommer til å fokusere på i de bivariate analysene der tjenestetilhørighet er en av variablene. For de andre tjenestetypene er antallet respondenter rett og slett for lavt til at forsvarlige sammenligninger lar seg gjøre.

Både innenfor kommunal helse- og omsorgstjeneste og spesialisthelsetjenesten er det en ganske stor andel som oppgir at de jobber innenfor andre tjenester enn de som var oppgitt. En rask gjennomgang viste at sykepleiere jobber innenfor veldig mange ulike deler av helsevesenet. Blant de fra kommunalhelsetjenesten som krysset "annet" var det en del som hadde skrevet inn sykehus.

Ellers ser vi at de kommunale frisklivssentralene er beskjedent representert i dataene. Dette er noe overraskende med tanke på at dette blir beskrevet som en viktig helsefremmende og forebyggende helsetjeneste, som skal hjelpe folk til å leve mer helsevennlige liv ved å tilby kunnskapsbasert og effektiv hjelp til å endre levevaner. Frisklivssentralene er et kommunalt tilbud der en skulle forvente stort engasjement rundt de temaene som denne unders $\varnothing$ kelsen adresserer. En mulig forklaring er at det ikke er så mange sykepleiere som jobber innenfor denne tjenesten, men vi har ingen oversikt over dette. Det samme kan muligens forklare den lave oppslutningen fra spesialisthelsetjenester som lærings- og mestringssenter/mestringsskole og arbeidsrettet rehabilitering, der en i utgangspunktet skulle forvente stort engasjement rundt disse temaene.

Ulempen med dette spørsmålet (innenfor hvilken del av helse- og omsorgssektoren jobber du?) er at en del sykepleiere, som følge av at de jobber innenfor flere tjenester (også kombinasjonen spesialist- og kommunehelsetjenesten), telles med to ganger. Den eneste måten å håndtere dette på er å inkludere alle observasjoner (avkrysninger i dataene), men det fører da til at en del sykepleiere (og deres erfaringer) telles med to ganger.

De sykepleierne som krysset av for at de jobber i kommunehelsetjenesten ble også spurt om antall innbyggere i den kommunen som de jobber i. Dette for å få et bilde på hvor godt bredden i norske kommuner var representert i dataene.

Tabell 4 Størrelse på kommunen som sykepleiere innenfor kommunehelsetjenesten jobber i. Antall og prosent.

\begin{tabular}{lrc}
\hline Kommunest $\varnothing$ rrelse (antall innbyggere) & Antall & Prosent \\
\hline 0-1999 & 28 & 2,5 \\
$2000-4999$ & 114 & 10,1 \\
$5000-9999$ & 141 & 12,5 \\
$10000-19999$ & 178 & 15,8 \\
$20000-29999$ & 144 & 12,8 \\
$30000-39999$ & 96 & 8,5 \\
$40000-49999$ & 79 & 7 \\
$50000+$ & 346 & 30,7 \\
\hline Totalt & 1126 & 100 \\
\hline
\end{tabular}

Nær én av tre sykepleiere jobber i en storbykommune (50000 innbyggere +). Ellers ser vi en brukbar spredning på de ulike kommunestørrelsene. Sykepleierne ble også spurt om hva de jobber som. Svarene fordelte seg slik:

$\begin{array}{lll}\text { PROSJEKTNR } & \text { RAPPORTNR } & \text { VERSJON } \\ 102010334 & \text { SINTEF A27128 } & 1.0\end{array}$




\section{(9) SINTEF}

Tabell 5 Hva jobber du som? Antall og prosent.

\begin{tabular}{lrr}
\hline Hva jobber du som? & Antall & Prosent \\
\hline Sykepleier (klinisk utøvende) & 1264 & 63,4 \\
Leder (mellomleder/enhetsleder/avdelingsleder) & 284 & 14,2 \\
Administrativt ansatt (saksbehandling etc.) & 84 & 4,2 \\
Faglig rådgiver & 94 & 4,7 \\
Annet & 268 & 13,4 \\
\hline Totalt & 1994 & 100 \\
\hline
\end{tabular}

Et klart flertall jobber som sykepleier (klinisk utøvende). Det var også denne gruppen vi i størst grad ønsket å nå ut til, fordi det er her det meste av pasientkontakten og -oppfølgingen skjer. Det er de klinisk utøvende sykepleierne som er mest relevant $i$ denne kartleggingen. Ellers ser vi at ledere utgjør en annen viktig kategori. Drøyt 14 prosent av sykepleierne har krysset av for at de er ledere. 268 sykepleiere krysset av for "annet" på dette spørsmålet. En rask gjennomgang viste at den rommet en rekke ulike stillingstyper, der helsesøster og jordmor var de vanligste.

Videre ble det kartlagt hvilke(n) aldersgruppe(r) av pasienter sykepleierne jobber med. Også her kunne de selvsagt krysse av for flere alternativer.

Tabell 6 Aldersgruppe(r) sykepleierne jobber inn mot. Antall og prosent.

\begin{tabular}{lc}
\hline Aldersgruppe & Antall \\
\hline Barn (0-6 år) & 592 \\
Barn (7-12 år) & 589 \\
Ungdom (13-18 år) & 690 \\
Voksne (19-64 år) & 1306 \\
Eldre (65 år og eldre) & 1270 \\
\hline Totalt & 4447 \\
\hline
\end{tabular}

Som vi ser av tabellen er det svært vanlig blant sykepleiere å jobbe opp mot ulike aldersgrupper. Mens 1938 unike personer har svart på spørsmålet, så er det krysset av hele 4447 ganger, noe som viser at sykepleierne i utvalget "i gjennomsnitt" jobber med 2,3 aldersgrupper. En konsekvens av dette er at det ikke gir mening å bruke "pasientenes aldersgruppe" som en variabel i de bivariate analysene, siden mange av sykepleierne i utvalget jobber med flere aldersgrupper. Følgelig kan ikke de, og deres erfaringer og synspunkter, knyttes til en enkelt aldersgruppe.

Også stillingsprosent blant sykepleierne ble kartlagt som en del av undersøkelsen. Grunnen til det var at stillingsprosent, på linje med arbeidstidsordning og stilling, kan ses på som rammevilkår som påvirker sykepleiernes muligheter til å jobbe helsefremmende og forebyggende. Nesten 84 prosent viste seg å ha en stillingsandel på mellom 76-100 prosent: 


\section{(9) SINTEF}

Tabell 7 Stillingsprosent blant sykepleierne i utvalget. Antall og prosent.

\begin{tabular}{lrr}
\hline Hva er din stillingsprosent? & Antall & Prosent \\
\hline $0-25 \%$ & 17 & 0,9 \\
$26-50 \%$ & 77 & 3,9 \\
$51-75 \%$ & 228 & 11,5 \\
$76-100 \%$ (inkludert stillingsandel over $100 \%)$ & 1663 & 83,8 \\
\hline Totalt & 1985 & 100 \\
\hline
\end{tabular}

Også når det gjelder stillingsandel ser vi at utvalget kjennetegnes av lite empirisk variasjon, noe som også gjør denne variabelen lite relevant for analysene. 54 respondenter unnlot å svare på dette spørsmålet.

Et annet forhold som vi var opptatt av å kartlegge var sykepleiernes arbeidstidsordning. Arbeidstidsordning kan ses på som et organisatorisk og administrativt rammevilkår, som innvirker på sykepleiernes arbeidshverdag og på organiseringen av tjenestene. Både for den enkelte sykepleier og for tjenestene vil det være en forskjell på om det hovedsakelig jobbes dagtid eller om arbeidet er organisert gjennom turnusordninger. Siden dette må kunne antas å påvirke "folkehelseinnsatsen" i helse- og omsorgstjenestene, spurte vi sykepleierne om deres arbeidstidsordning. Svarene fordelte seg slik:

Tabell 8 Arbeidstidsordning blant sykepleierne i utvalget. Antall og prosent.

\begin{tabular}{lrr}
\hline Hvilken arbeidstidsordning har du? & Antall & Prosent \\
\hline Hovedsakelig dagtid & 1007 & 51 \\
Hovedsakelig kveld & 14 & 0,7 \\
Hovedsakelig natt & 90 & 4,6 \\
Turnus & 863 & 43,7 \\
\hline Total & 1974 & 100 \\
\hline
\end{tabular}

Et knapt flertall jobber hovedsakelig dagtid (51 prosent). I tillegg er det en stor gruppe som jobber turnus (43,7 prosent). Andelen som jobber kveld eller natt er lav - i analysene velger vi derfor å skille mellom de to vanligste arbeidstidsordningene, nemlig turnus og dagtid.

Som en del av kartleggingen av sykepleiernes bakgrunn spurte vi også om hvor mange år de hadde jobbet som sykepleier/spesialsykepleier i helse- og omsorgssektoren:

Tabell 9 Hvor mange år har du jobbet som sykepleier/spesialsykepleier i helse- og omsorgssektoren? Antall og prosent.

\begin{tabular}{lrr}
\hline & Antall & Prosent \\
\hline 11 år eller lengre & 1594 & 80,1 \\
$6-10$ år & 345 & 17,4 \\
$2-5$ år & 45 & 2,3 \\
Under 2 år & 5 & 0,3 \\
\hline Total & 1989 & 100 \\
\hline
\end{tabular}

80 prosent av sykepleierne har jobbet som sykepleier i 11 år eller mer. Når det gjelder de med minst erfaring (under to år), så er det kun fem sykepleiere (0,25 prosent) som har det. NSF har uttrykt at de ikke 


\section{(9) SINTEF}

er overrasket over at det er en veldig lav svarprosent i denne gruppen. De mangler arbeidsforhold på veldig mange av de nyutdannede, og når det gjelder nyutdannede med arbeidsforhold, så utgjør de kun 3-4 prosent av totalt antall yrkesaktive medlemmer i NSF. De uten registrerte arbeidsforhold kunne heller ikke bli med i uttrekket, siden dette baserte seg på hvor medlemmene jobber.

Som et siste bakgrunns-spørsmål ble sykepleierne spurt om de har spesial- eller videreutdanning. Om lag tre av fire sykepleiere i utvalget bekreftet at de hadde det:

Tabell 10 Har du spesial- eller videreutdanning? Antall og prosent.

\begin{tabular}{lcc}
\hline Spesial- eller videreutdanning? & Antall & Prosent \\
\hline Ja & 1482 & 74,7 \\
Nei & 502 & 25,3 \\
\hline Total & 1984 & 100 \\
\hline
\end{tabular}

De som svarte ja ble med egne ord bedt om å utdype hvilken utdanning de hadde. Dette genererte en lang liste over ulike utdanninger, blant annet fordi ulike skrivemåter og ulike begreper (brukt om samme utdanning) ble registrert som "ulike" utdanninger. Vi har ikke hatt tid å foreta en manuell opptelling av alle utdanningstypene, men en rask gjennomgang viste at spesialisering som helsesøster og intensivsykepleier er to av de vanligste. Andre viktige fagområder for spesialisering og videreutdanning blant sykepleierne $\mathrm{i}$ utvalget er psykisk helsearbeid, psykiatri, operasjonssykepleier, anestesi og geriatri. 


\section{Resultater fra spørreundersøkelsen og intervjuene}

I dette kapitlet presenterer vi resultatene fra spørreundersøkelsen og intervjuene. Presentasjonen av resultater er organisert under de temaoverskriftene som strukturerte spørreskjemaet. Under de ulike temaene presenteres en del tabeller som viser fordelinger mellom to variabler (bivariate tabeller). Dette for å se om svarfordelingen på ulike spørsmål varierer avhengig av hvilken del av helse- og omsorgstjenesten sykepleierne jobber innenfor, og hvilken arbeidstidsordning de har. Som allerede påpekt måtte en del av de andre bakgrunnsvariablene droppes fra analysene, grunnet skjeve svarfordelinger.

\subsection{Kunnskap og erfaringer med helsefremmende og forebyggende arbeid}

I spørreundersøkelsen ble sykepleierne presentert for flere påstander som omhandlet deres erfaringer med, og synspunkter på helsefremmende og forebyggende tiltak. Svarene fordelte seg slik:

Jeg synes helsefremmende arbeid som begrep er

"ullent" og vanskelig å forholde seg til i min daglige jobb $(\mathrm{N}=1722)$

Jeg synes forebyggende arbeid som begrep er "ullent" og vanskelig å forholde seg til i min daglige jobb ( $\mathrm{N}=1722)$

Det er for store forventninger til hva sykepleierne innenfor kommune- og spesialisthelsetjenesten kan bidra med når det gjelder helsefremmende og forebyggende arbeid $(\mathrm{N}=1722)$

Jeg har for dårlig kunnskap om helsefremmende og forebyggende arbeid ( $\mathrm{N}=1727$ )

Det er en viktigere del av min jobb å behandle/lindre sykdom enn å forebygge fremtidig sykdom $(\mathrm{N}=1718)$

Hovedansvaret for å ivareta det helseforebyggende arbeidet ligger hos fastlegene og i kommunehelsetjenesten $(\mathrm{N}=1731)$

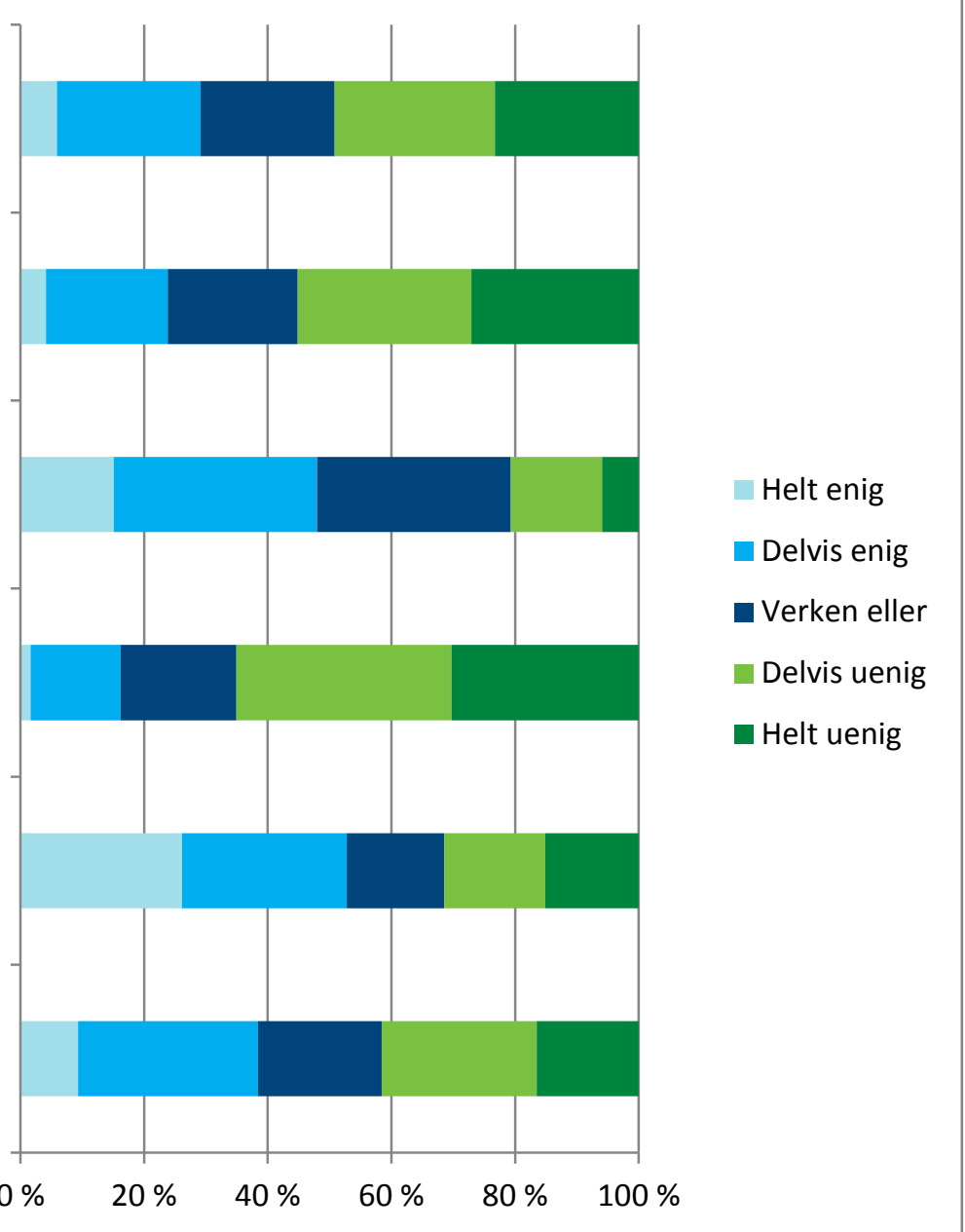

Figur 2 Påstander som omhandler sykepleiernes erfaringer med å jobbe helsefremmende og forebyggende. Prosent, hele utvalget.

Nesten 30 prosent av sykepleierne i utvalget synes helsefremmende arbeid som begrep er "ullent" og vanskelig å forholde seg til i sin daglige jobb (de fleste svarer riktignok "delvis enig"). Ut fra 


\section{(9) SINTEF}

svarfordelingene virker forebyggende arbeid å ha et noe mer tydelig innhold; her svarer knapt 25 prosent at de synes begrepet er ullent og vanskelig å forholde seg til i det daglige. Alt i alt gir tallene grunnlag for å hevde at det er et visst potensial for å øke kunnskapen og forståelsen rundt disse begrepene. Dersom vi antar at sykepleierne i utvalget i snitt er mer involvert og engasjert i folkehelsearbeid enn sykepleiere flest, så er det enda sterkere grunn til å hevde dette. Samtidig er det viktig å ta med seg at andelen som synes de to begrepene er greie å forholde seg til i det daglige, er større. Andelen som oppgir at begrepene er helt forståelige for dem (svarer "helt uenig") er henholdsvis 23 og 27 prosent. Alt i alt mener vi likevel tallene synliggjør et behov for $\varnothing k t$ kunnskap og forståelse av disse begrepene, og ikke minst hvordan de kan integreres og utøves innenfor ulike helse- og omsorgstjenester. Det at om lag 20 prosent svarer verken/eller til de to påstandene, kan også tjene som en bekreftelse på dette.

På disse punktene er det mange likhetstrekk med hvordan sykepleiere i intervjuene snakker om, og forstår folkehelse på sin arbeidsplass:

"[Folkehelse] er ikke et fokus. Det er ikke sånn at vi snakker om folkehelse i den forstand, men vi skal jo tenke som så at det vi gjør, det skal i siste instans forebygge så langt som mulig at de [brukerne] ikke kommer på sykehjem. Eller at de trenger flere tjenester fra oss (...) så vi tenker ikke folkehelse $i$ den forstand, men vi prøver jo det vi kan, å legge til rette for at folk skal klare seg mest mulig selv, og det er jo å opprettholde egenomsorg, rett og slett" (Hjemmesykepleie, kommune 2)

"Når jeg tenker folkehelse, så tenker jeg mer helhetlig helse. At man tenker på forebygging av sykdom, at man er føre var med fysisk aktivitet, bra kosthold og et sosialt nettverk. Og venner. Det ser jeg på som folkehelse (...) Folkehelse tenker jeg er livskvalitet" (Psykiatrisk sykepleier, kommune 5)

"Jeg tenker at alt vi gjør her for at den enkelte bedre skal mestre sitt liv er folkehelsearbeid." (Somatisk avd. sykehus)

Som vi ser fra intervjusitatene bruker informantene begrep som forebygging, opprettholde egenomsorg, klare seg lengst mulig selv, helthetlig helse, livskvalitet og mestring av eget liv når de snakker om hvordan de arbeider. Det kan dermed lett oppstå en oppfatning av sykepleiere - og blant sykepleierne selv - at de ikke jobber med folkehelse. En av informantene setter ord på nettopp denne utfordringen:

"Jeg tenker at det er ganske viktig at vi som sykepleiere vet at det vi driver med faktisk er folkehelse. I stedet for at folkehelse er "helsestasjon for eldre", eller det de driver med på rådgivernivå. Det har betydning - å kalle det vi gjør i det daglige for folkehelse!" (Hjemmesykepleie, kommune 2)

Samtidig er det viktig å peke på at mange sykepleiere trolig arbeider ut i fra en forebyggende/helsefremmende tilnærming, men de bruker ikke begrepet "folkehelse" når de omtaler sitt eget arbeid.

Figur 2 viser ellers at andelen som mener de har for dårlig kunnskap om helsefremmende og forebyggende arbeid er lav; kun 1,6 prosent er helt enig i dette, mens 15 prosent er delvis enig. 65 prosent mener at de har god kunnskap (uenig i påstanden). Det er imidlertid viktig å skille mellom det å ha kunnskap om disse begrepene på den ene side, og det å skulle anvende dem i eget arbeid. God kunnskap og bevissthet hos den enkelte sykepleier vil ikke være nok; en rekke andre rammebetingelser må være på plass dersom et helhetlig folkehelsearbeid skal være mulig. 


\section{(9) SINTEF}

Nesten halvparten er helt eller delvis enig i påstanden om at det er for store forventninger til hva sykepleierne innenfor kommune- og spesialisthelsetjenesten kan bidra med når det gjelder helsefremmende og forebyggende arbeid. Her er det litt vanskelig å vite hva som springer ut av egne erfaringer, og hva som mer kan sies å være et synspunkt eller en holdning. Videre ser vi at over halvparten sier seg helt eller delvis enig i påstanden om at det er en viktigere del av deres jobb å behandle/lindre sykdom enn å forebygge fremtidig sykdom. Kanskje bør disse resultatene ses i sammenheng; dersom man er av den oppfatning at primæroppgaven er å lindre og behandle sykdom, så vil man fort kunne mene at omgivelsene har for store forventninger til hva sykepleierne innenfor kommune- og spesialisthelsetjenesten kan utrette når det gjelder helsefremmende og forebyggende arbeid.

Når det gjelder påstanden om i hvilken grad hovedansvaret for å ivareta det forebyggende helsearbeidet ligger hos fastlegene/kommunehelsetjenesten eller ikke, så er utvalget ganske delt; andelen som sier seg enig og uenig er nesten like stor. Fra samme batteri har vi også noen andre påstander, men som i større grad berører sykepleiernes erfaringer med pasienter og pasientenes rolle og betydning for sykepleiernes mulighet til å jobbe helsefremmende og forebyggende:

Det å veilede pasientene om hvordan de kan leve et mer helsevennlig liv ser jeg på som en viktig del av min jobb $(\mathrm{N}=1739)$

Jeg er avhengig av å ha en god dialog med pasientene for å kunne veilede dem om hvordan de skal leve helsevennlige liv ( $N=1726)$

Mange pasienter trenger å bli fortalt konkret hvordan de skal leve mer helsevennlig ( $\mathrm{N}=1734)$

I et helseperspektiv erfarer jeg ofte at det er vel så viktig å fokusere på den enkeltes ressurser, sosiale situasjon og livsstil som den konkrete sykdommen/diagnosen $(N=1725)$

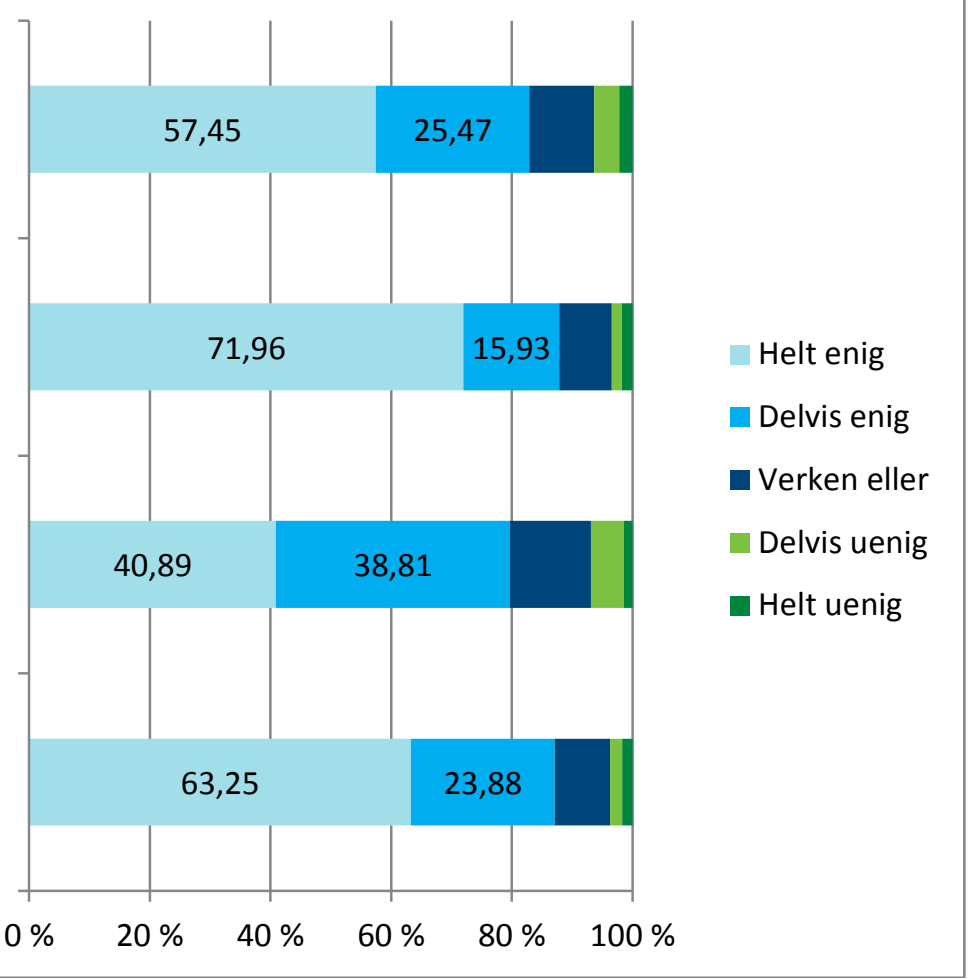

Figur 3 Sykepleiernes erfaringer med å jobbe helsefremmende og forebyggende-med et pasientperspektiv. Prosent, hele utvalget.

Det tydeligste resultatet i figur 3 er at 72 prosent av sykepleierne i utvalget er helt enig i påstanden om at de er avhengig av å ha en god dialog med pasientene for å kunne veilede dem om hvordan de skal leve helsevennlige liv. 16 prosent sier seg delvis enig. Implikasjonen er utvetydig; god dialog med pasientene er en forutsetning for å kunne gjennomføre helsefremmende og forebyggende tiltak. Ellers er det et interessant resultat at over 80 prosent av sykepleierne mener at det er en viktig del av deres jobb å veilede pasientene om hvordan de kan leve et mer helsevennlig liv. Siden dette kan "romme" både lindrende 


\section{(9) SINTEF}

behandling så vel som forebyggende tiltak (informasjon og veiledning), så må det sies å være et godt utgangspunkt for å kunne implementere folkehelseperspektivet $i$ enda større grad innenfor helse- og omsorgstjenestene.

Cirka 80 prosent av sykepleierne i utvalget bekrefter at mange pasienter trenger å bli fortalt konkret hvordan de skal leve mer helsevennlig. Sykepleierne har, gjennom sin pasientnærhet, en nøkkelrolle i den sammenheng. Samtidig er det interessant å notere seg at hele 63 prosent er av den klare oppfatning (helt enig) at det i et helseperspektiv ofte kan være vel så viktig å fokusere på den enkeltes ressurser, sosiale situasjon og livsstil, som sykdommen eller den medisinske diagnosen. Knapt 24 prosent er delvis enig $\mathrm{i}$ påstanden. Resultatet gir et sterkt signal om hvor viktig det er å ha en bred tilnærming til pasientene, og gir god støtte til folkehelseperspektivet og anvendelsen av helsefremmende og forebyggende tiltak.

I det følgende ser vi nærmere på noen av påstandene, og skiller mellom ledere og "vanlige" sykepleiere. Er det en forskjell på hva man mener om forebyggende og helsefremmende arbeid $\mathrm{i}$ helse- og omsorgstjenesten, avhengig av om man er leder eller primært jobber med pasienter? For å belyse dette har vi plukket ut noen av de påstandene som vi synes var mest relevante med tanke på å synliggjøre eventuelle forskjeller mellom ledere og vanlig ansatte, og der vi samtidig fant en viss forskjell i svarmønsteret mellom de to gruppene:

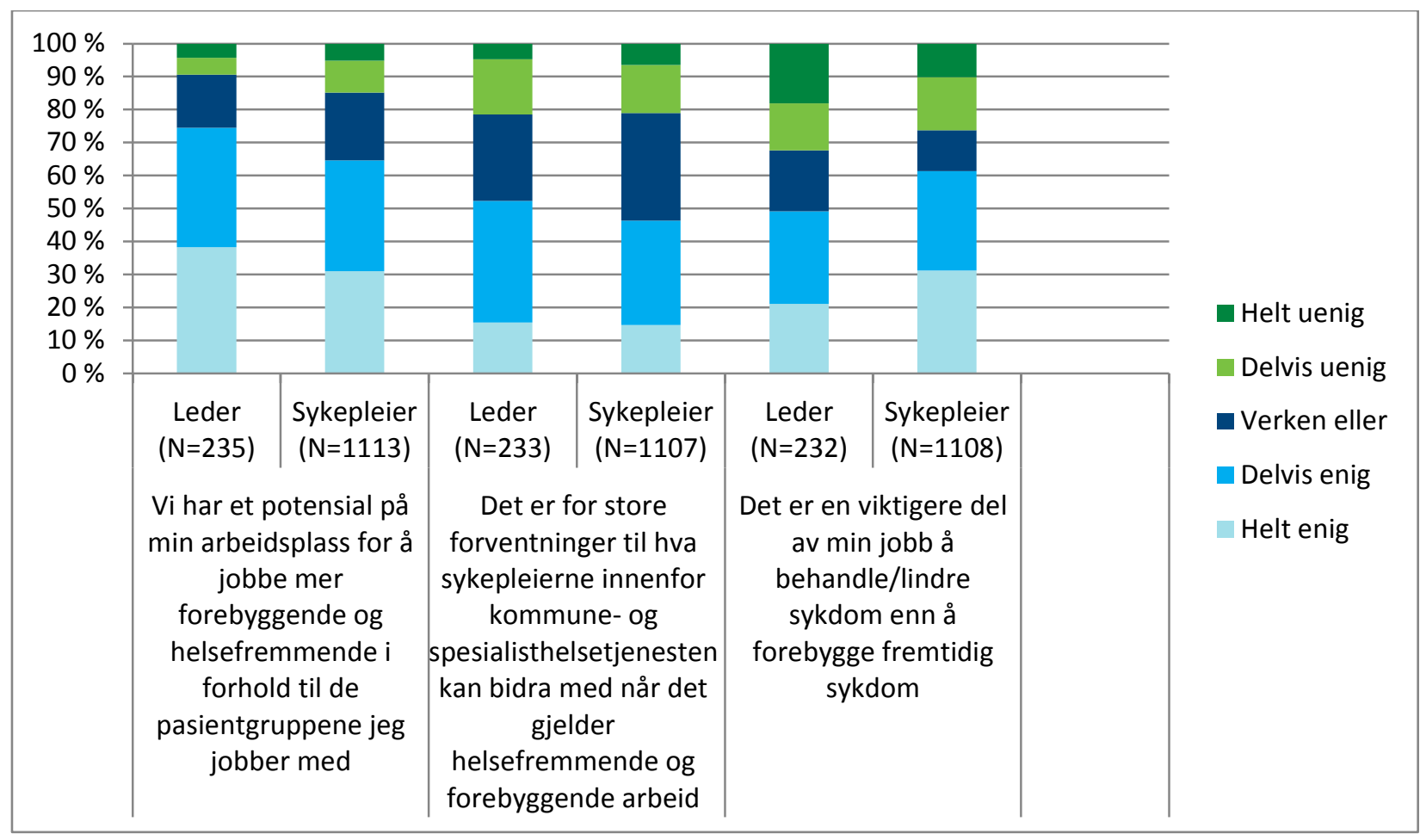

Figur 4: Erfaringer med å jobbe helsefremmende og forebyggende-fordelt på om man jobber som leder eller sykepleier (klinisk).

En større andel blant lederne mener at de på egen arbeidsplass har et potensial for å jobbe mer forebyggende og helsefremmende. Dette gjelder for 38,3 prosent av lederne (helt enig) og 31 prosent av sykepleierne (helt enig). Tilsvarende andeler som svarer delvis enig er på 36 og 33,6 prosent. Det er ikke 


\section{(9) SINTEF}

overraskende at en større andel blant lederne gir uttrykk for en slik holdning, og forklaringene kan være flere. En mulig tolkning er at mange ledere er bedre kvalifisert til å mene noe om dette enn sykepleiere som jobber operativt, rett og slett fordi de har bedre oversikt over arbeidsplassen totalt sett og kjenner "potensialet". Det kan også handle om forventninger, og at ledere har større forventninger til at helsefremmende og forebyggende strategier skal tas i bruk. Vi kan heller ikke se bort fra at enkelte ledere har vært opptatt av å svare i tråd med de krav og forventninger som kommer fra nivåer over dem og samfunnet omkring. Folkehelseperspektivet er veldig aktuelt, selv om det kan være utfordrende å konkretisere og implementere i en praktisk kontekst.

Ellers er det interessant å notere seg at en større andel blant lederne mener at det er for store forventninger til hva sykepleierne innenfor kommune- og spesialisthelsetjenesten kan bidra med når det gjelder helsefremmende og forebyggende arbeid (52,4 prosent av lederne, mot 46,3 av sykepleierne, er helt eller delvis enig i påstanden). En mulig tolkning er at siden det er avdelingsledere og enhetsledere som har hovedansvaret for å legge til rette for at helsefremmende og forebyggende tiltak kan gjennomføres, så er de også godt posisjonert til å observere at dette er krevende å få til innenfor de rammer og ressurser som er til rådighet.

Endelig ser vi en ganske klar forskjell når det gjelder påstanden om det er en viktigere del av den enkeltes jobb å behandle/lindre sykdom enn å forebygge fremtidig sykdom. 31 prosent av sykepleierne er helt enig $\mathrm{i}$ påstanden, mens tilsvarende andel blant lederne er 21 prosent. At det er en forskjell mellom de to gruppene er egentlig som forventet. Når det gjelder de andre påstandene, så oppgir lederne å ha noe bedre kunnskap enn vanlige sykepleiere. De synes i litt mindre grad at begrepene helsefremmende og forebyggende arbeid er vanskelige å forholde seg til, og mener i større grad enn sykepleierne at de ved egen enhet kommer tidlig i gang med en helsefremmende og forebyggende tilnærming overfor pasientene.

\subsection{Hvilke folkehelsetemaer prioriteres?}

I det følgende presenterer vi tall som viser i hvilken grad ulike folkehelsetemaer blir prioritert av sykepleierne i deres daglige arbeid. For å synliggjøre bedre hvilke temaer som skiller seg ut, har vi i figuren rangert dem etter relevans, basert på hvor vanlig (svært vanlig + ganske vanlig) temaet er i respondentenes oppfølging av pasientene. 


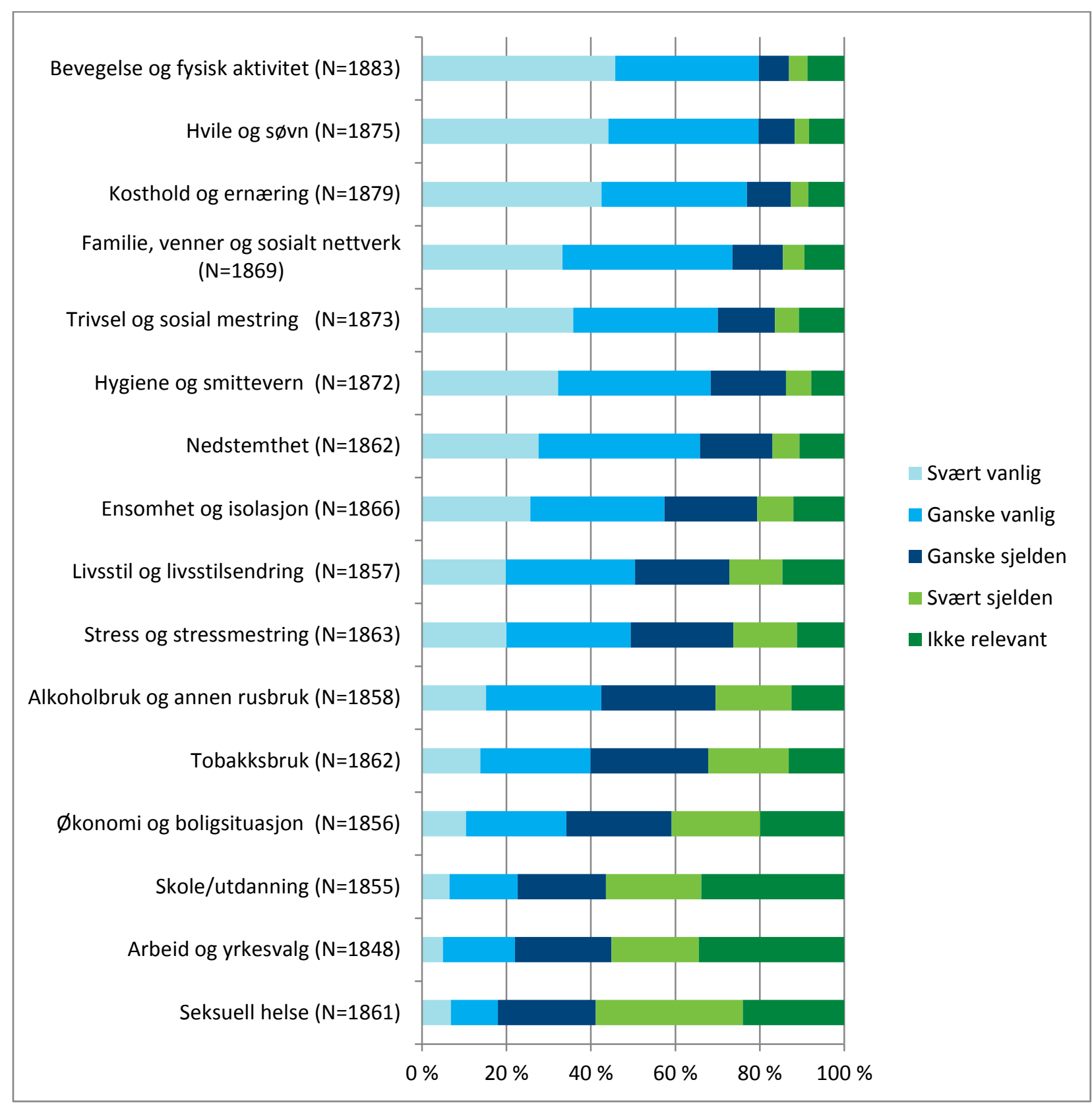

Figur 5 Hvor vanlig er de følgende temaene i den oppfølgingen og dialogen du har med dine pasienter/pasientgrupper? Prosent, hele utvalget.

Som figuren viser er det noen temaer som skiller seg mer ut enn andre. Bevegelse og fysisk aktivitet, hvile og søvn samt kosthold og ernæring er de tre områdene som peker seg ut som mest vanlig å ha som en del av pasientoppfølgingen. Det er med andre ord en dominans av det vi kan kalle mer "tradisjonelle" folkehelsetemaer (jf. Riksrevisjonen, 2015). Familie, venner og sosialt nettverk, samt trivsel og sosial mestring, er andre temaer som ser ut til å bli prioritert. Livsstil og livsstilsendring, samt alkoholbruk og annen rusbruk og tobakksbruk, er mindre vanlig å fokusere på. Økonomi, arbeid, utdanning og seksuell helse er de temaene som sykepleierne i minst grad fokuserer på i oppfølgingen av pasientene. 


\section{(9) SINTEF}

Vi ønsker her å knytte en ekstra kommentar til dette med livsstil og livsstilsendringer, som vi mener er et område som har et enormt potensial $i$ et folkehelseperspektiv. Én grunn til dette er at livsstil kan sies å være en "samlekategori", som tar opp i seg mange av de andre temaene som ligger inne i figur 5 (som for eksempel kosthold, fysisk aktivitet, alkohol- og tobakksbruk, rusmiddelbruk samt døgnrytme og søvn). En tilnærming der man legger spesiell vekt på pasientenes livsstil og "livsrytme" vil derfor kunne gi en stor folkehelsegevinst.

I de neste figurene har vi sett nærmere på noen av de samme temaene, men nå fordelt på hvilken tjeneste sykepleierne jobber innenfor. Gjennom å se de ulike folkehelseindikatorene i sammenheng med tjenestetilhørighet, kan vi få et klarere bilde av forskjeller i prioritering og rammebetingelser på tvers av tjenester. Når det gjelder tjeneste, så har vi plukket ut de seks tjenestene innenfor kommunehelsetjenesten og spesialisthelsetjenesten med størst antall respondenter (tre i hver). Vi presenterer seks figurer, som tematisk får frem spennvidden $\mathrm{i}$ folkehelsetematikken. Tilsvarende figurer for de $\varnothing v r i g e$ folkehelseindikatorene finnes i vedlegg 1 bakerst i rapporten.

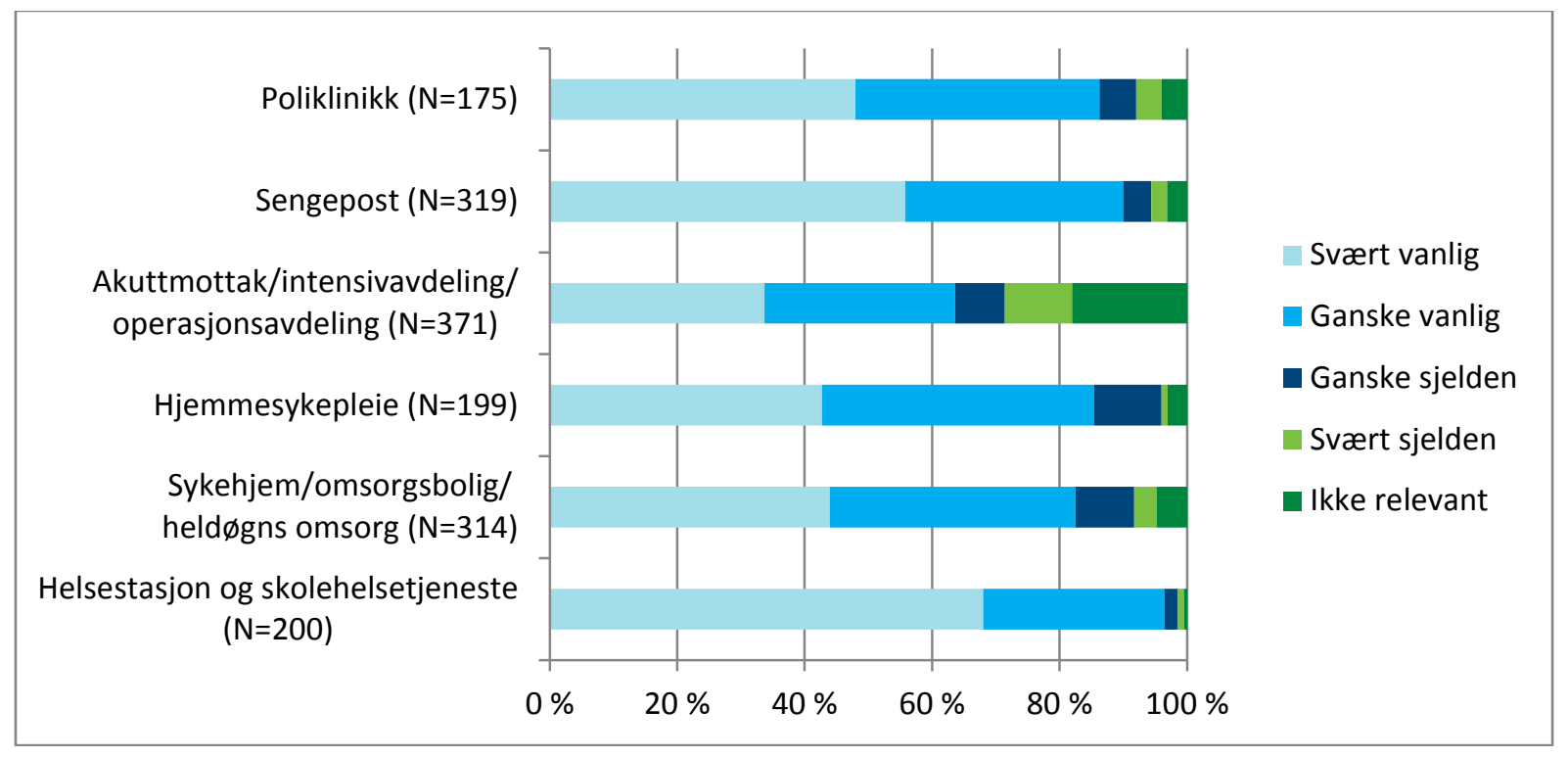

Figur 6 Hvor vanlig er det at de følgende temaene er en del av den oppfølgingen og dialogen som du har med dine pasienter? Bevegelse og fysisk aktivitet. 


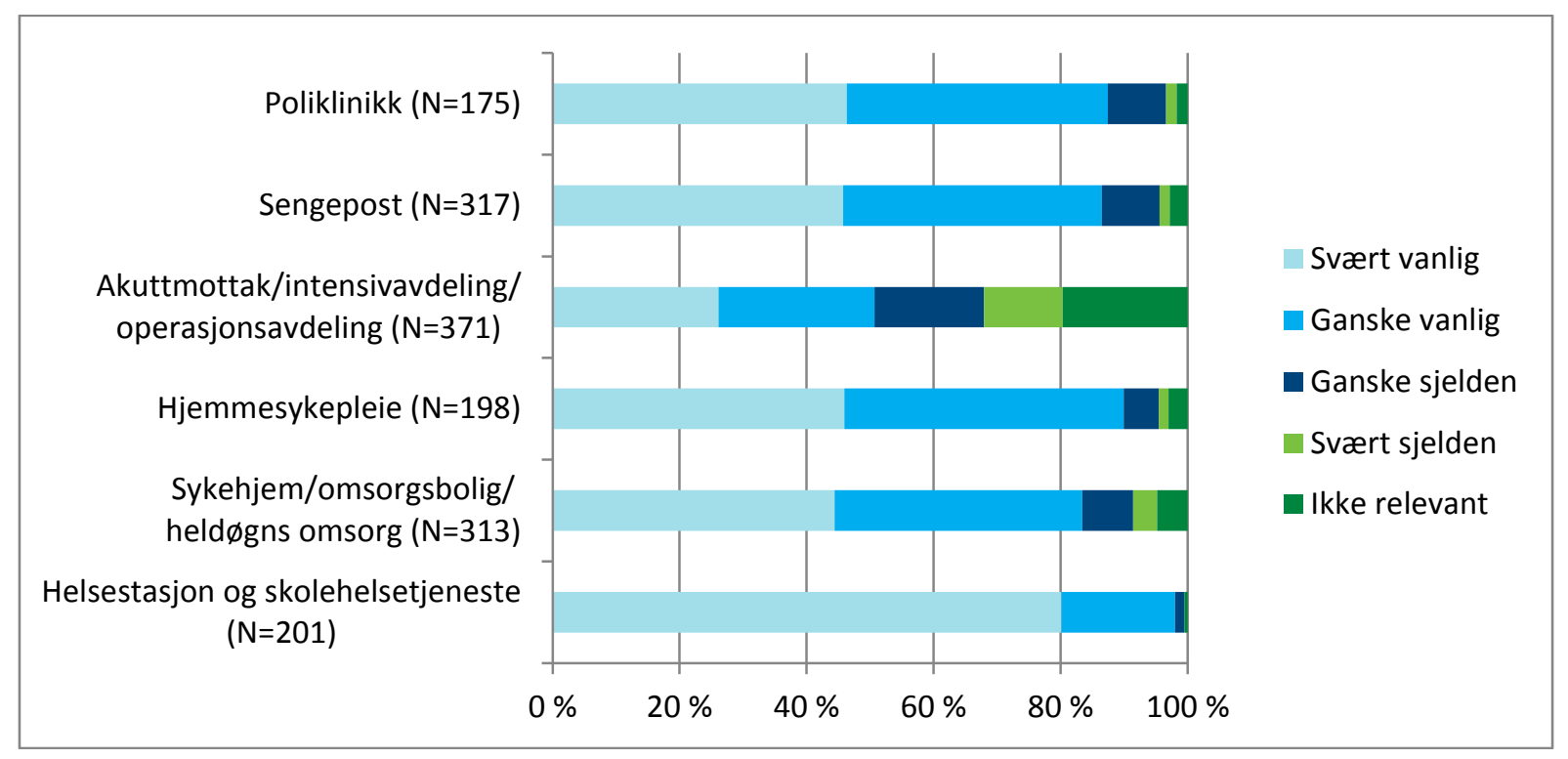

Figur 7 Hvor vanlig er det at de følgende temaene er en del av den oppfølgingen og dialogen som du har med dine pasienter? Kosthold og ernæring.

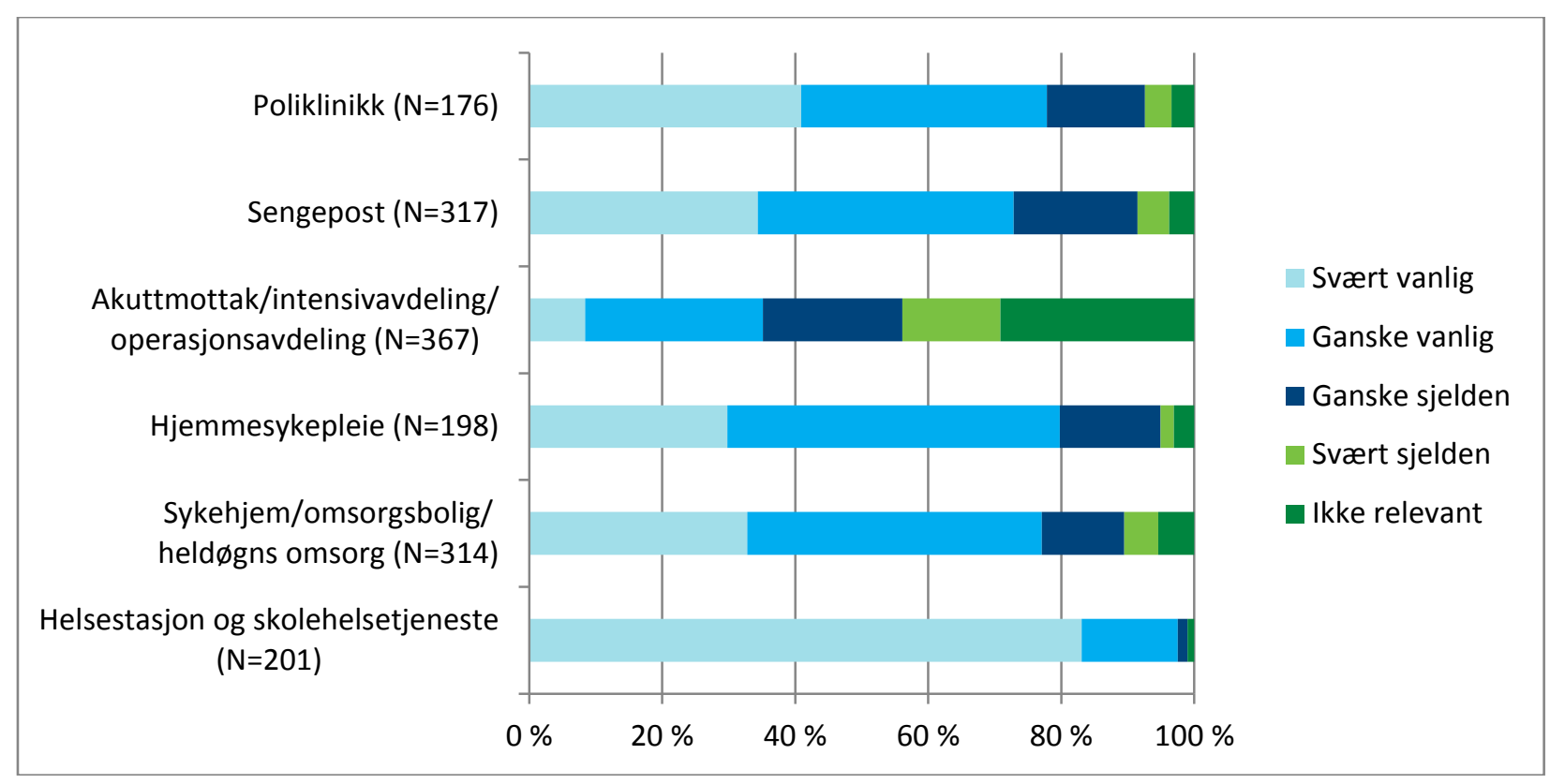

Figur 8 Hvor vanlig er det at de følgende temaene er en del av den oppfølgingen og dialogen som du har med dine pasienter? Trivsel og sosial mestring. 


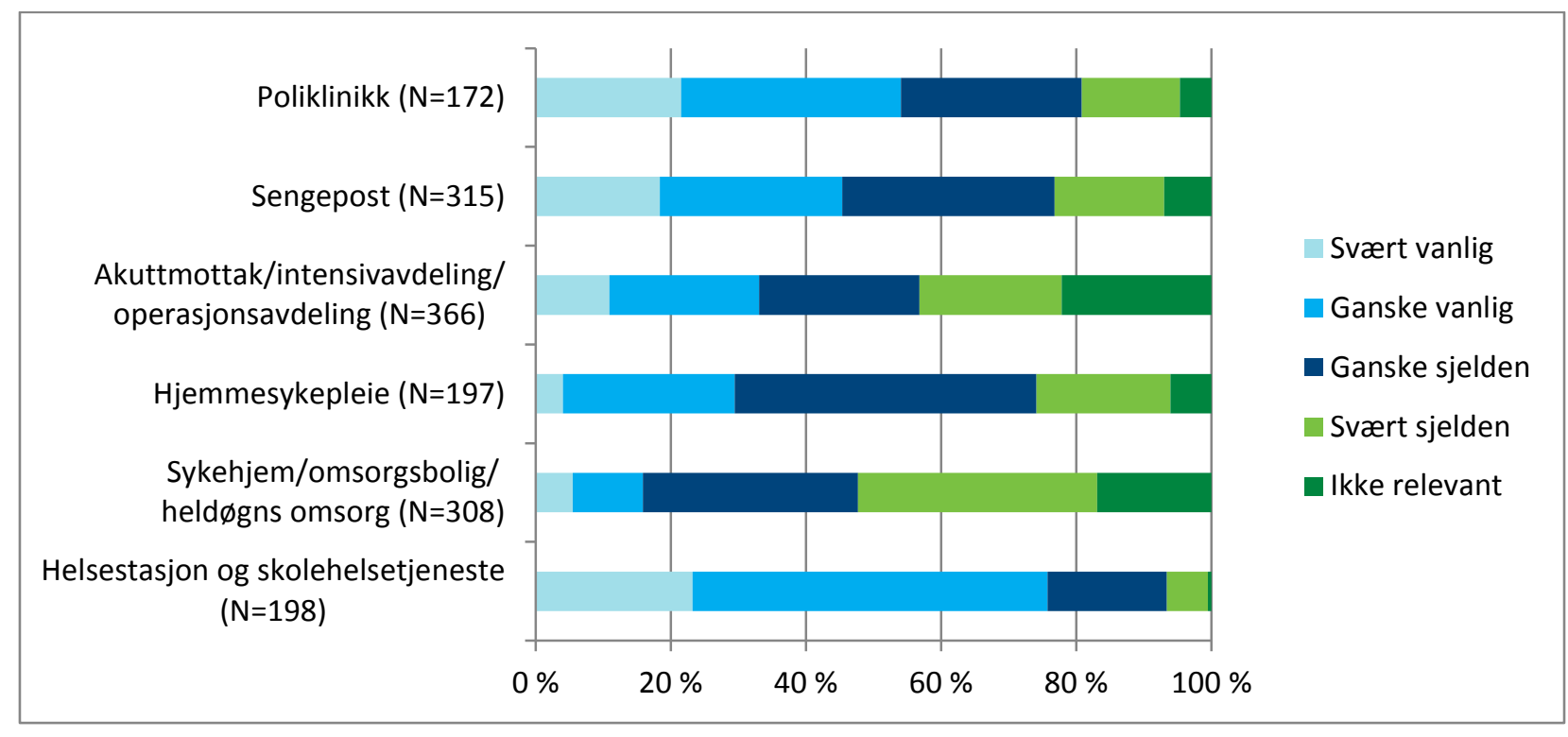

Figur 9 Hvor vanlig er det at de følgende temaene er en del av den oppfølgingen og dialogen som du har med dine pasienter? Alkoholbruk og annen rusbruk.

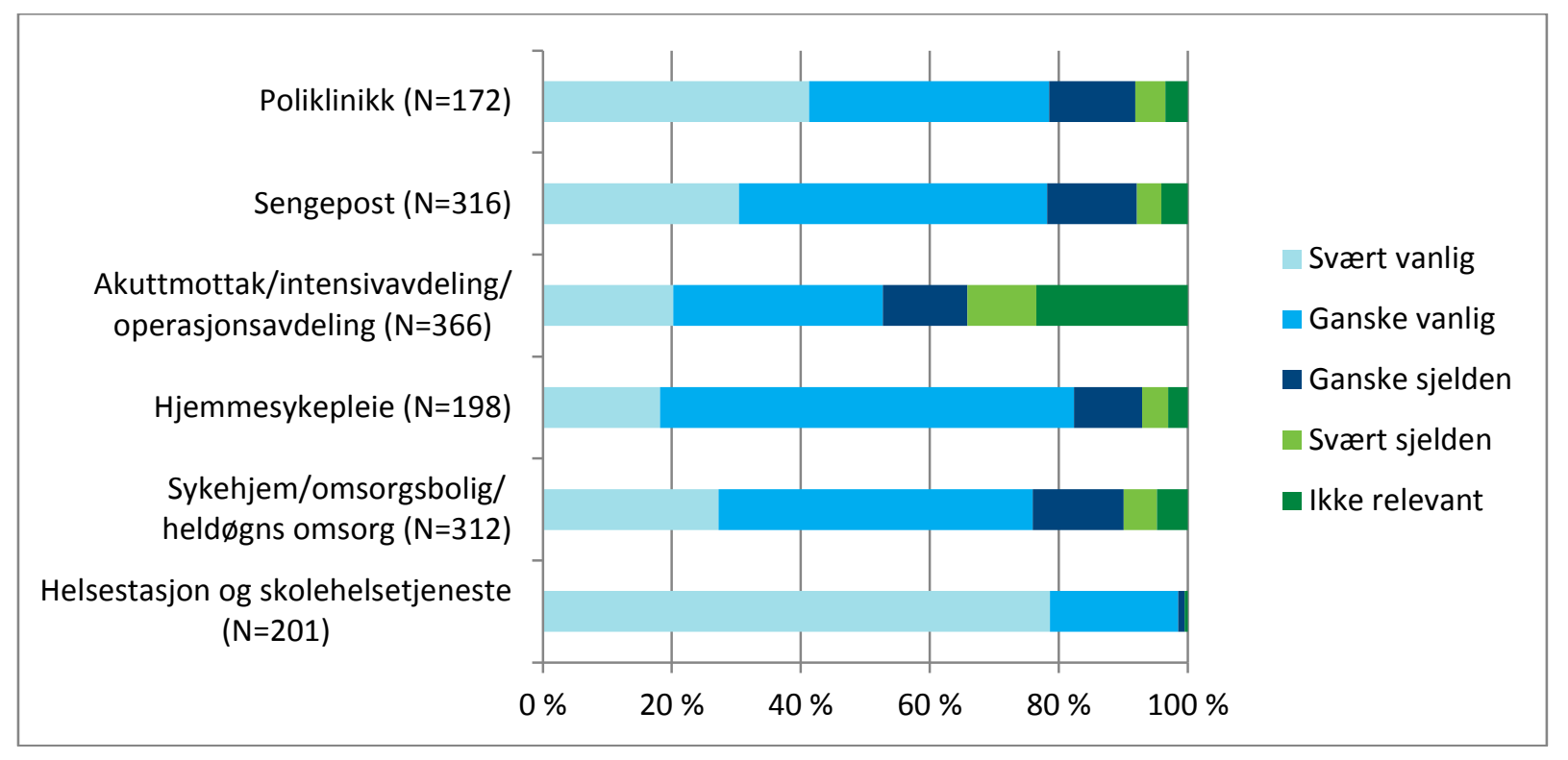

Figur 10 Hvor vanlig er det at de følgende temaene er en del av den oppfølgingen og dialogen som du har med dine pasienter? Familie, venner og sosialt nettverk. 


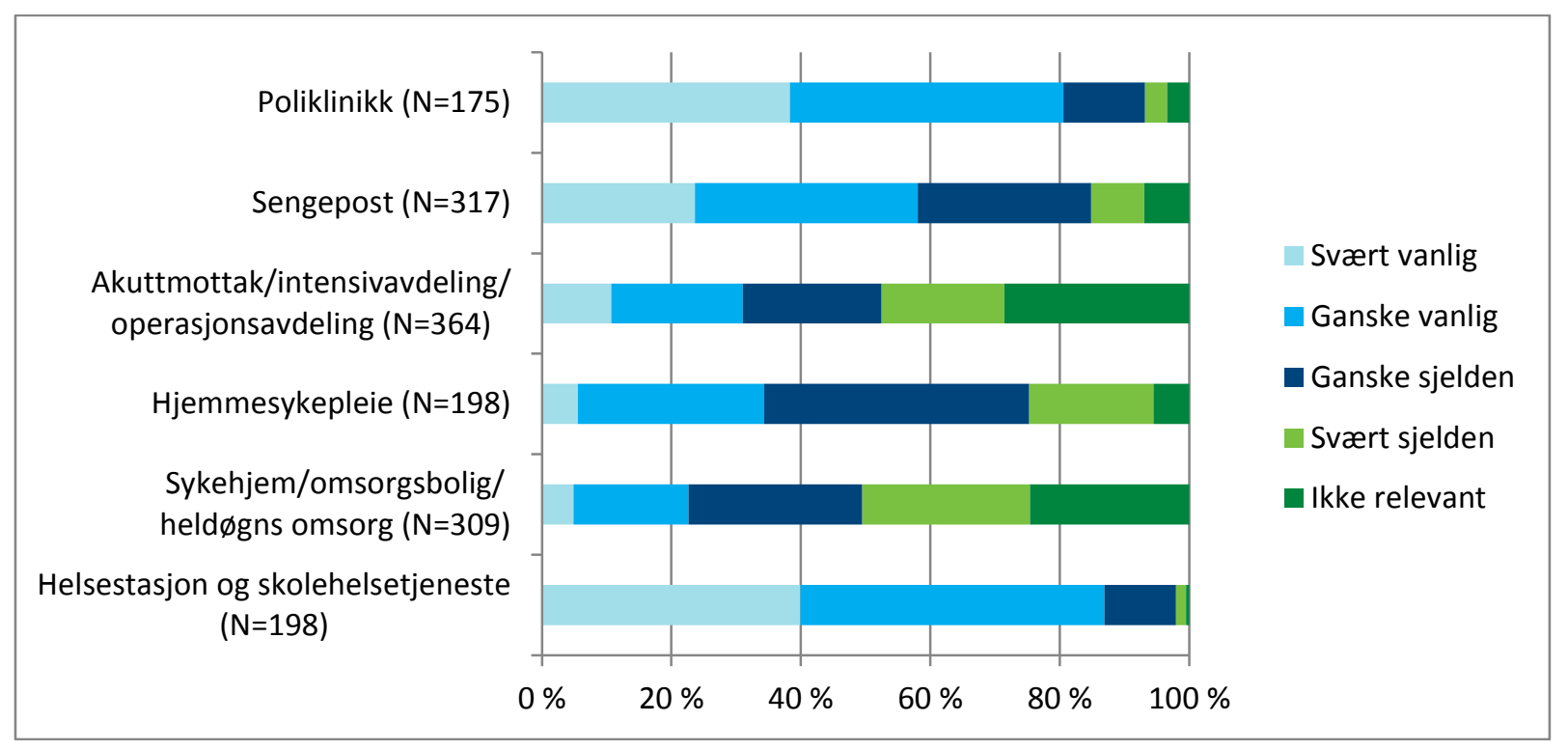

Figur 11 Hvor vanlig er det at de følgende temaene er en del av den oppfølgingen og dialogen som du har med dine pasienter? Livsstil og livsstilsendring.

Som vi så foran er bevegelse og fysisk aktivitet det området som er mest vanlig å fokusere på i oppfølgingen av pasientene, uavhengig av tjenestetype. Oppsplittingen på tjenestetype viser imidlertid en ganske stor variasjon på tvers av tjenestene, der akuttmottak/intensivavdeling peker seg ut som den tjenesten der informasjon og oppfølging rundt fysisk helse og bevegelse er minst vanlig. Tidsperspektivet på pasientkontakten spiller trolig inn her. På et akuttmottak har de mindre mulighet til å etablere kontakt med pasientene, fordi det er en større gjennomstrømming av pasienter enn det eksempelvis er innenfor de kommunale helsetjenestene, noe følgende uttalelse fra en psykiatrisk sykepleier i en kommune illustrerer:

"Det er ikke sånn at jeg sitter og tenker på folkehelse i det daglige, men det jeg tenker på i det daglige for eksempel er jeg veldig opptatt av dette med fysisk aktivitet og psykisk helse. Jeg synes at det har en stor sammenheng. Og likens det med kosthold, så er det jo sammenheng med psykisk helse. Det er en del av jobben vår" (Psykiatrisk sykepleier, kommune 3)

En psykiatrisk sykepleier i kommunen har gjerne en langvarig relasjon med brukerne, og selv om ikke informanten selv nødvendigvis tenker at hun utøver "folkehelsearbeid", er hun daglig opptatt av å aktivisere brukerne, samt fokusere på kosthold. Informanten oppfatter dette som en naturlig del av jobben sin. Slik ser vi at egenskaper ved tjenesten er med på å definere "rommet" for å drive med helsefremmende og forebyggende arbeid.

Når det gjelder kosthold og ernæring så er dette et tema som mange av informantene tok opp i intervjuene. Kosthold og ernæring er også et av de "klassiske" temaene innenfor folkehelsearbeid og innenfor sykepleie generelt. Som figur 7 viser er kosthold og ernæring noe helsestasjon og skolehelsetjenesten svært ofte tar opp med brukerne. Dette utdypes av en av informantene som jobber som helsesøster: 


\section{(9) SINTEF}

"Det er veldig mange spørsmål om kost. Det er et veldig stort behov. Mange som lurer på veldig mye. Og det er mange som er usikre, for det er jo så mye informasjon i media-både det ene og det andre rådet. Men jeg opplever at de fleste gjør som de vil likevel" (Helsesøster, kommune 8)

I underkant av halvparten av respondentene i sykehjem oppgir at de tar opp kosthold og ernæring med beboerne. En av informantene ansatt ved en langtidsavdeling på sykehjem trekker fram betydningen måltidet har for de eldre:

"De skal få nok mat, og de skal få god mat, og mat når de ønsker det etter deres behov. Måltidet er mange ganger et høydepunkt om dagen, så det å ordne en fin ramme rundt måltid, det er viktig når man jobber med eldre" (Sykehjem, kommune 2)

Slike utsagn kan tolkes i retning av at kost, ernæring og måltid kan få mye oppmerksomhet blant ansatte i sykehjem - uavhengig av om de snakker med beboerne om det eller ei. Et annet gjennomgående funn er at sykepleierne innenfor helsestasjon/skolehelsetjeneste er den gruppen som i klart størst grad har de ulike temaene som en del av sin dialog og oppfølging med brukerne. Som vi kommer tilbake til senere $i$ rapporten, er dette som forventet, når vi vet at dette er en tjeneste som skal nå bredt ut til barn og ungdom, geografisk så vel som tematisk. Det er heller ikke overraskende at sykepleiere i skolehelsetjenesten ser ut til å være mer opptatt av temaer som hvile og søvn, og trivsel og mestring enn sykepleiere $\mathrm{i}$ andre tjenester, i og med at dette er temaer som er relevante overfor målgruppen for tjenesten, nemlig barn og unge i skolealder. Det samme kan sies om familie, venner og sosialt nettverk, som var et av de vanligste temaene uavhengig av tjenestetype, men som er mest vanlig å fokusere på innenfor helsestasjon/skolehelsetjeneste; nesten 79 prosent av sykepleierne svarer at dette er noe de svært ofte tar opp i sin dialog med brukerne.

Resultatene viser at det er en ganske stor variasjon mellom de seks tjenestene, når det gjelder de ulike "innsatsområdene" og hvordan disse blir prioritert. Helsestasjon/skolehelsetjeneste skiller seg ut innenfor alle innsatsområdene, som en tjeneste der alle temaer ser ut til å være en naturlig del av det tilbudet som gis overfor pasientene/brukerne. Alt i alt underbygger resultatene antakelsen om at tjenestetype fungerer som et rammevilkår, som påvirker $\mathrm{i}$ hvilken grad ulike folkehelsetemaer er en integrert del av tjenestetilbudet.

Sett opp mot en slik bakgrunn er det heller ikke overraskende at temaer som arbeid, økonomi og utdanning er mindre vanlig å fokusere på innenfor ulike deler av helsetjenesten. Kjennetegn ved pasientene, og ikke minst den tiden man har til rådighet (pasientgjennomstrømning), varierer på tvers av tjenestene. Overfor en del pasientgrupper vil det rett og slett være unaturlig for sykepleierne å ta opp disse temaene. Hvilke temaer som er aktuelle vil med andre ord variere på tvers av tjenester og pasientgrupper, og vil også avhenge av hvor syke og behandlingstrengende pasientene er.

\subsection{Kompetanse og utdanning}

For bedre å kunne forstå de erfaringene og synspunktene som sykepleierne har knyttet til det å jobbe helsefremmende og forebyggende, stilte vi noen spørsmål om deres faglige kunnskap og forutsetninger. Neste figur viser hvordan respondentene vurderer betydningen av egen utdanning for den kompetanse de har innenfor forebyggende og helsefremmende arbeid. 


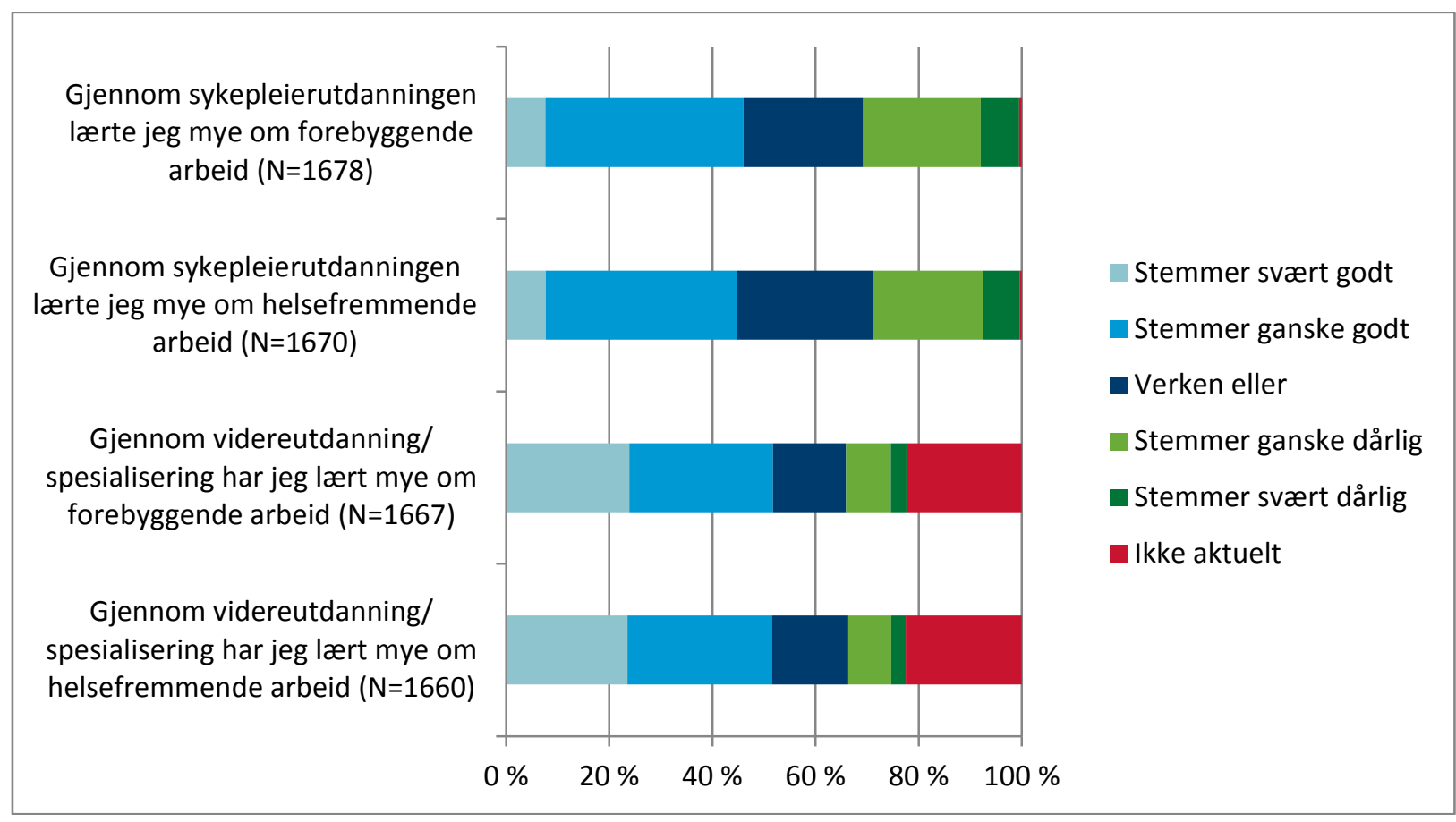

Figur 12 Sykepleiernes vurdering av egen kunnskap og egne forutsetninger for å jobbe helsefremmende og forebyggende. Prosent, hele utvalget.

Når det gjelder innhold i utdanningen, så er andelen som opplever at de har lært mye om helsefremmende og forebyggende arbeid relativt lav; mellom sju og åtte prosent mener at de to påstandene stemmer svært godt for deres del. 37 prosent mener påstanden stemmer ganske godt når det gjelder helsefremmende arbeid, mens 38 prosent svarer det samme når det gjelder forebyggende arbeid. Andelene som mener at de gjennom sykepleierutdanningen ikke lærte mye om verken helsefremmende eller forebyggende arbeid, er på henholdsvis 28 og 30 prosent. Dessuten er andelen som svarer verken/eller høy; 26,35 (på helsefremmende arbeid) og 23,24 prosent (på forebyggende arbeid).

Svarene fra informantene varierer noe i deres vurdering og refleksjon omkring egen kompetanse og sykepleiere generelt sin kompetanse på folkehelse. En leder på en somatisk klinikk i spesialisthelsetjenesten sa følgende:

"Relatert til barn, så er en sykepleier med vanlig bachelor veldig lite rustet til det [å jobbe med et folkehelseperspektiv]. De har veldig lite oversikt over hvordan det kommunale hjelpeapparatet fungerer overfor barn. De har veldig lite undervisning om barn" (Somatisk avd., sykehus)

En annen leder peker også på manglende undervisning i folkehelse på sykepleierutdanningen:

"Potensialet er der, men jeg tror at da må man starte med utdanningen. Å få det mye tydeligere inn der. At vi skal forebygge i tillegg til å behandle. Det er helt klart viktig" (Kommune 4)

Majoriteten av sykepleierne vi intervjuet, syntes imidlertid at sykepleierutdanningen hadde gjort dem godt rustet til å jobbe forebyggende og helsefremmende: 
"Det er helt grunnleggende i min utdanning. Både primærforbyggende og sekundærforebyggende er jo sånt som ligger i grunnutdanningen, $i$ hvert fall da jeg gikk på midten av 80-tallet (...) Forebyggende helsearbeid er jo faktisk en del av sykepleierutdanningen i Norge, og det er den faktisk ikke i alle andre land. Du blir ikke sykepleier i Norge uten" (Psykiatrisk sykepleier, kommune 1)

"Det er jo sånn tenker jeg, at dette [folkehelseperspektivet] har vi jo lært: det å begrense og forebygge helsesvikt. Det ligger jo til grunn for alt vi gjør" (...) Det ligger jo i bunnen; at du skal gjøre tilværelsen så god som mulig for den pasienten du har" (Sykehjem, kommune 2)

Når det gjelder videreutdanning/spesialisering, ser vi at andelen som sier seg helt enig i at de har lært mye om helsefremmende og forebyggende arbeid er langt høyere, nærmere bestemt 24 prosent for begge.

I neste figur presenteres flere påstander som omhandler sykepleiernes kunnskap om helsefremmende og forebyggende arbeid.

Det meste jeg kan om forebyggende og helsefremmende arbeid har jeg lært gjennom arbeidet mitt ( $\mathrm{N}=1671)$

Jeg kjenner til lovkravet om kommunal folkehelseplan ( $\mathrm{N}=1672$ )

Jeg har behov for mer kunnskap om hvordan jeg kan jobbe forebyggende og helsefremmende overfor pasientene mine ( $\mathrm{N}=1665)$

Jeg $\emptyset$ nsker at vi hadde flere kurs/opplæring knyttet til folkehelsearbeid på arbeidsplassen min $(\mathrm{N}=1669)$

Jeg kjenner til og anvender kunnskapsbaserte metoder i mitt helsefremmende og forebyggende arbeid $(\mathrm{N}=1670)$

Jeg har god kunnskap om effektive metoder i endringsarbeid (eks, motiverende intervju) $(\mathrm{N}=1669)$

Jeg opplever å ha for liten flerkulturell kompetanse i møte med pasienter fra andre kulturer $(\mathrm{N}=1668)$

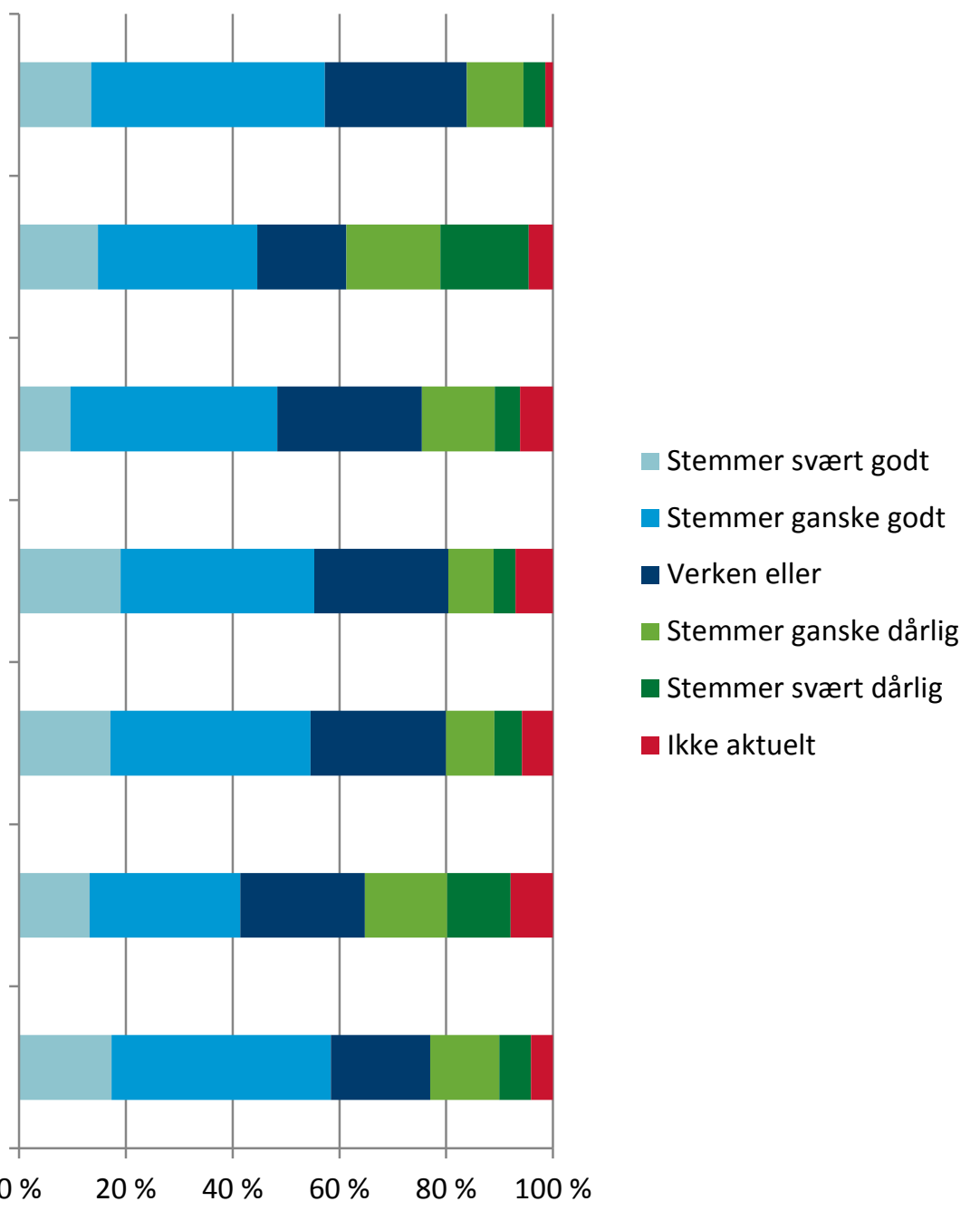

Figur 13 Kompetanse og forutsetninger for å kunne jobbe helsefremmende og forebyggende. Prosent, hele utvalget. 


\section{(9) SINTEF}

Også disse resultatene viser at det er et potensial for å styrke kunnskap og opplæring av sykepleiere i helsefremmende og forebyggende arbeid. Om lag halvparten av respondentene oppgir at de har behov for mer kunnskap om hvordan de kan jobbe forebyggende og helsefremmende overfor pasientene (stemmer svært godt og stemmer ganske godt), og over halvparten oppgir at de ønsker seg flere kurs.

Behovet for mer kunnskap ble også tatt opp i intervjuene. Flere av informantene snakker varmt om at sykepleiere bør ta masterutdanning. Gjennom en masterutdanning lærer en "å løfte blikket" og å tenke mer kunnskapsbasert. En informant (helsesøster) satte ord på kunnskapsbehovet på denne måten:

"Om vi er gode nok på folkehelsearbeid? Ja, det er vi i kraft av utdanningen vår og bakgrunnen som sykepleier. Men at folk er kunnskapssultne. Ja - folk vil veldig gjerne ha mer påfyll! (...) Og det er veldig viktig å være oppdatert, hvis ikke er det lite troverdig" (Helsesøster, kommune 6)

Når det gjelder flerkulturell kompetanse, så svarer nesten seks av ti sykepleiere (stemmer svært godt eller ganske godt) at dette er noe de opplever å ha for lite av i sitt møte med pasienter fra andre kulturer. Språklige barrierer, samt høy terskel for å oppsøke helsetjenesten i en del innvandrergrupper, vil kunne forsterke disse utfordringene. Når vi samtidig vet at folkehelseutfordringene er spesielt store i deler av innvandrerbefolkningen (Folkehelseinstituttet, 2014), er dette et klart uttrykk for at folkehelse og innvandrerhelse er områder som må prioriteres i helsetjenesten.

Ellers viser resultatene at arbeidsplassen ser ut til å fungere som en viktig læringsarena for helsefremmende og forebyggende arbeid. Cirka 57 prosent svarer (stemmer svært godt eller ganske godt) at det meste av det de vet om forebyggende og helsefremmende arbeid, har de lært gjennom arbeidet sitt. En viktig implikasjon av dette er at uansett hvor mye helsefremmende og forebyggende arbeid tas inn som tema i sykepleierutdanningen og i videreutdanning og spesialisering, så vil arbeidsplassen for mange fortsatt være den viktigste læringsarenaen. I møte med pasienter og kolleger virker det med andre ord å ligge en viktig arena for læring når det gjelder folkehelsearbeid. At folkehelseperspektivet er godt forankret på ledernivå vil imidlertid være viktig for at sykepleiere skal kunne jobbe på denne måten i det daglige.

\subsection{Innsats på folkehelsefeltet - tiltak og forebygging}

Vi ser nå nærmere på i hvilken grad sykepleierne bruker tid på folkehelsearbeid i det daglige. Vi ser også på hvor vanlig det er å jobbe med ulike former for forebygging (primær-, sekundær- og tertiærforebygging) samt variasjoner $i$ anvendelsen av universelle, selektive og indikative tiltak. I den første figuren presenteres sykepleiernes respons på et spørsmål som kartla hvor mye tid de bruker på helsefremmende og forebyggende arbeid, med utgangspunkt i en typisk arbeidsuke: 


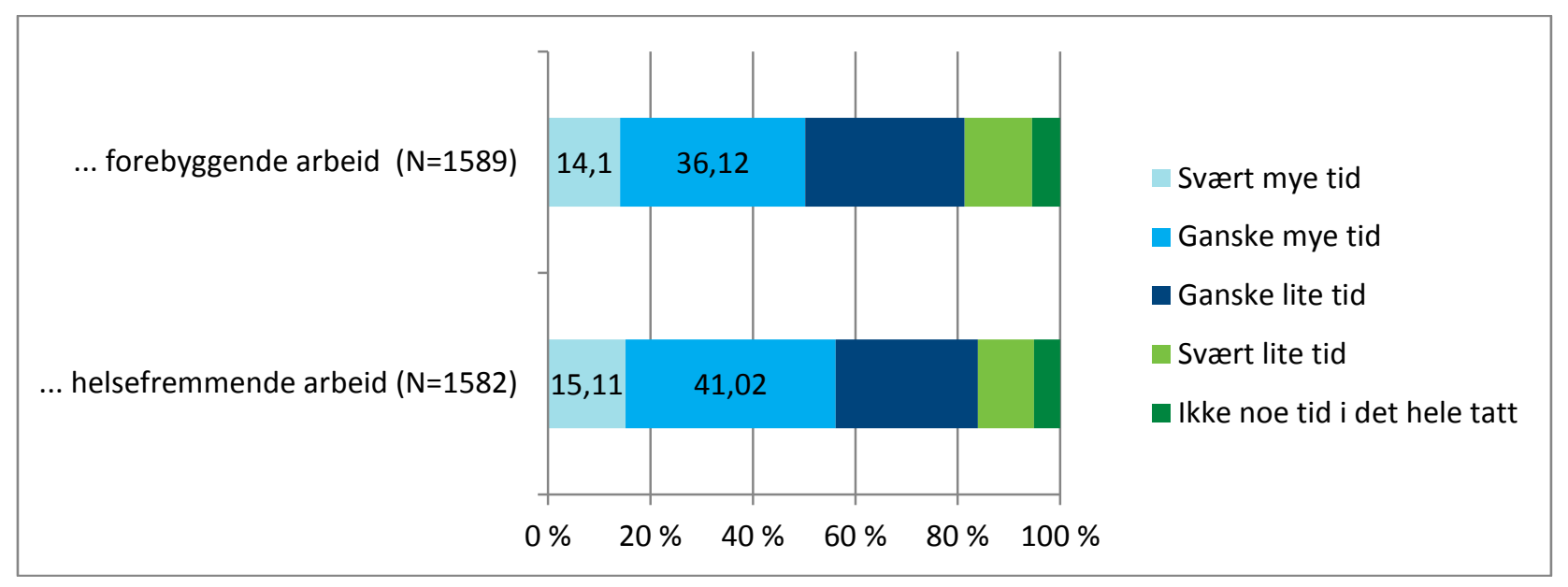

Figur 14 Tid brukt på helsefremmende og forebyggende (folkehelsearbeid). Prosent, hele utvalget.

Andelen som jobber med forebyggende og helsefremmende arbeid er ganske lik. Gitt tallene, og det tematiske overlappet mellom de to områdene, så er det grunn til å anta at det i stor grad er de samme personene som jobber med helsefremmende og forebyggende tiltak. Når det gjelder forebyggende arbeid, så ser vi at utvalget er delt på midten når det gjelder de som bruker tid og de som ikke bruker tid på det.

I de to neste figurene ser vi på de samme spørsmålene, men fordelt på de seks utvalgte tjenestene innenfor kommunehelsetjenesten og spesialisthelsetjenesten (jf. de tjenestene som hadde høyest antall respondenter i undersøkelsen). Også her er hensikten å avdekke om det er noen variasjoner på tvers av tjenestetype når det gjelder helsefremmende og forebyggende arbeid.

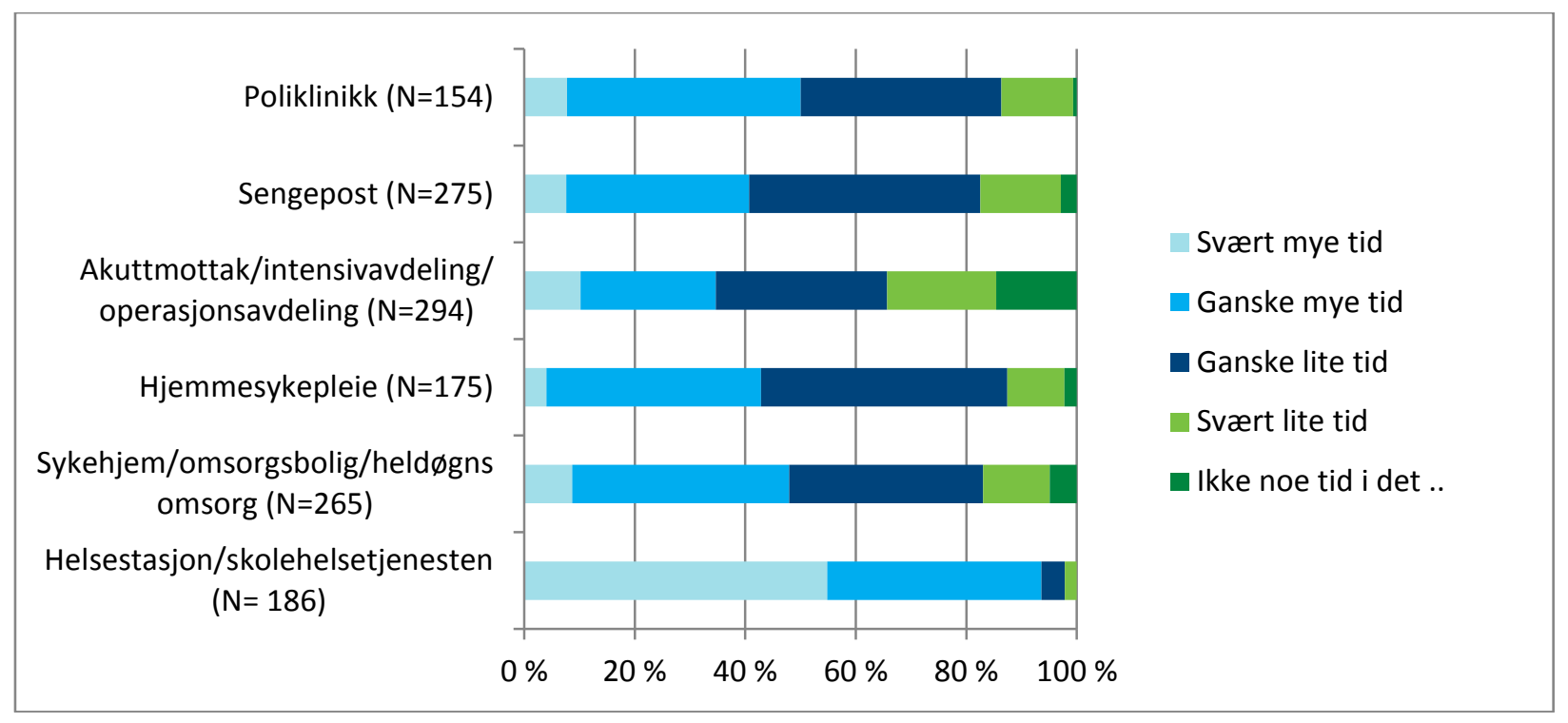

Figur 15 Ta utgangspunkt i en vanlig arbeidsuke for deg: Hvor mye tid vil du si at du bruker på forebyggende arbeid? Prosent, fordelt på tjenestetype. 


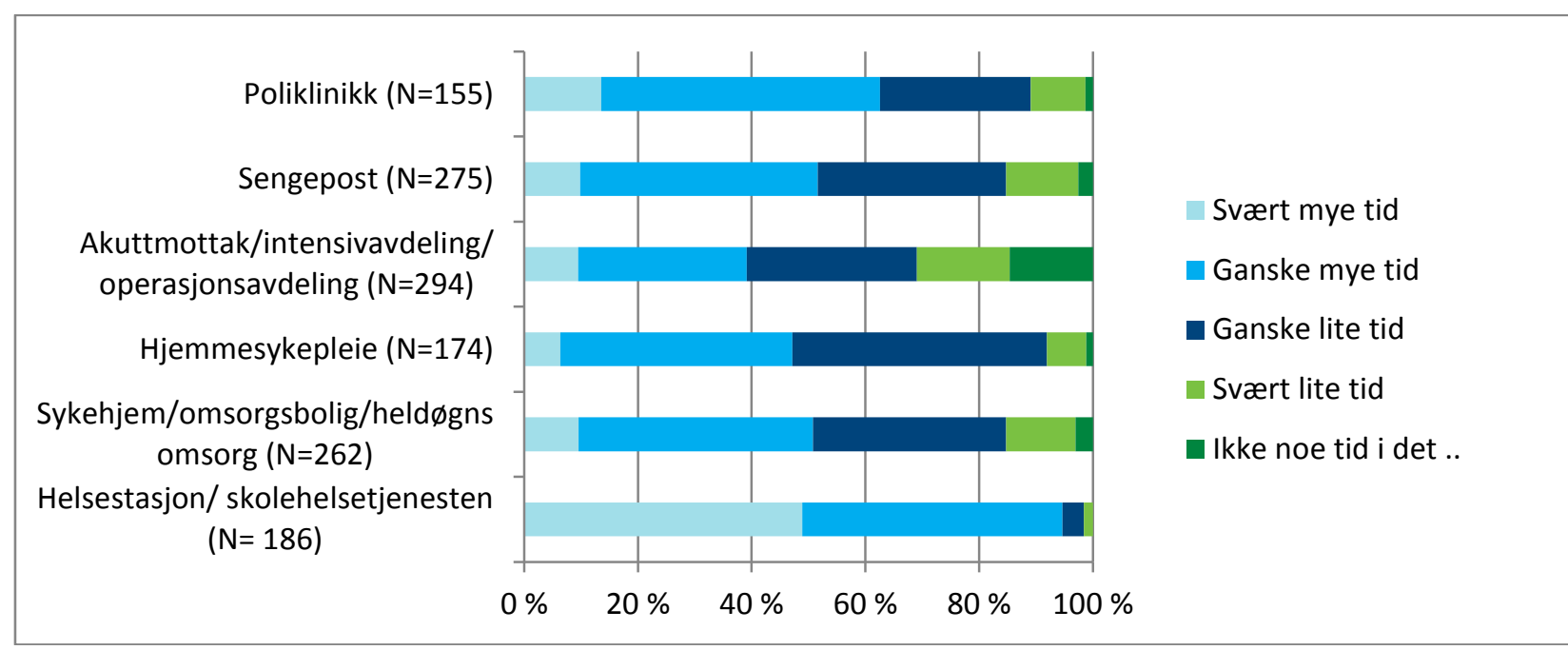

Figur 16 Ta utgangspunkt i en vanlig arbeidsuke for deg: Hvor mye tid vil du si at du bruker på helsefremmende arbeid? Prosent, fordelt på tjenestetype.

Nok en gang ser vi at sykepleierne innenfor helsestasjon/skolehelsetjeneste skiller seg ut. Dette er den gruppen som i klart størst grad oppgir å bruke mye tid på helsefremmende og forebyggende arbeid. Neste tabell viser i hvilken grad sykepleiere innenfor ulike tjenester jobber med ulike former for forebygging. $\mathrm{Vi}$ skiller mellom tre former for forebygging: primærforebygging, sekundærforebygging og tertiærforebygging. Mens primærforebygging handler om å forhindre at skade og sykdom i det hele tatt oppstår, handler sekundærforebygging om å hindre tilbakefall eller forverring av sykdom og skade. Tertiærforebygging skal minske følger for livskvalitet av sykdom og funksjonsnedsettelse.

Tabell 11 Antall og andel som jobber med ulike former for forebygging. Hele utvalget.

\begin{tabular}{lcc}
\hline & $\begin{array}{c}\text { Ja, jobber med } \\
\text { (antall) }\end{array}$ & $\begin{array}{c}\text { Andel som jobber } \\
\text { med (prosent) }\end{array}$ \\
\hline $\begin{array}{l}\text { Primærforebygging } \\
(N=1 \text { 599) }\end{array}$ & 592 & 37 \\
$\begin{array}{l}\text { Sekundærforebygging } \\
(N=1599)\end{array}$ & 1135 & 71 \\
$\begin{array}{l}\text { Tertiærforebygging } \\
(N=1599)\end{array}$ & 1181 & 73,9 \\
\hline
\end{tabular}

Tabellen viser at tertiærforebygging er den formen for forebygging som er mest vanlig å jobbe med, tett fulgt av sekundærforebygging. Felles for disse to er at de "betinger" at sykdom allerede er til stede. I kontrast til dette har primærforebygging til hensikt å svekke faktorer som medfører helserisiko, og heller styrke de faktorene som bidrar til god helse. I et forebyggende perspektiv vil derfor primærforebygging spille en spesielt viktig rolle, fordi det handler om å veilede og stimulere befolkningen til å leve mer helsevennlige liv. For sykepleiernes del er det imidlertid mindre vanlig å jobbe primærforebyggende enn sekundær- og tertiærforebyggende. Nok en gang er det grunn til å forvente at hvilken tjeneste sykepleierne jobber innenfor, vil ha betydning. For å finne ut mer om dette, har vi i de neste tabellene lagt inn tjenestetype. 


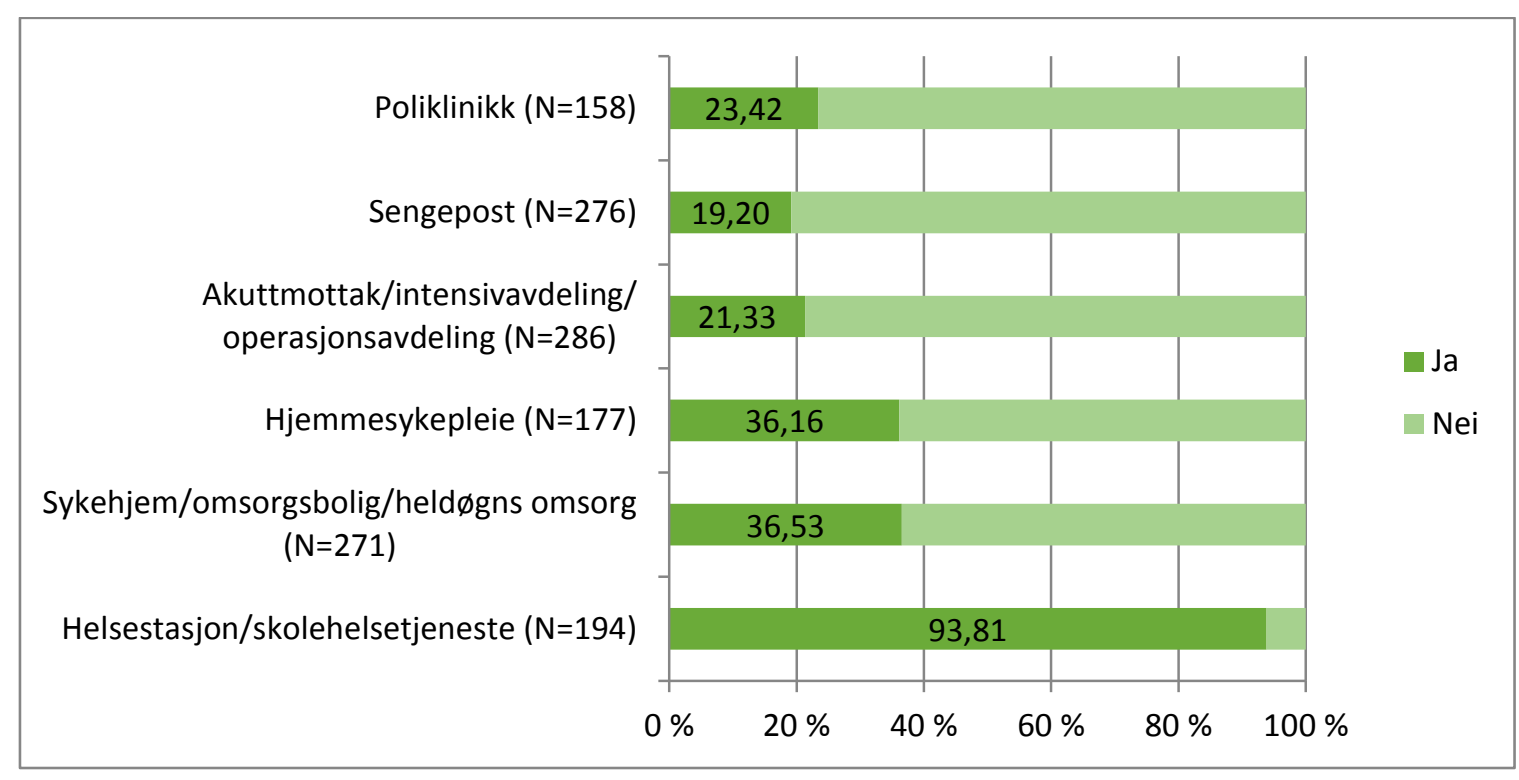

Figur 17 Jobber du primærforebyggende (før oppståtte helseproblemer/sykdom)? Prosent, fordelt på tjenestetype.

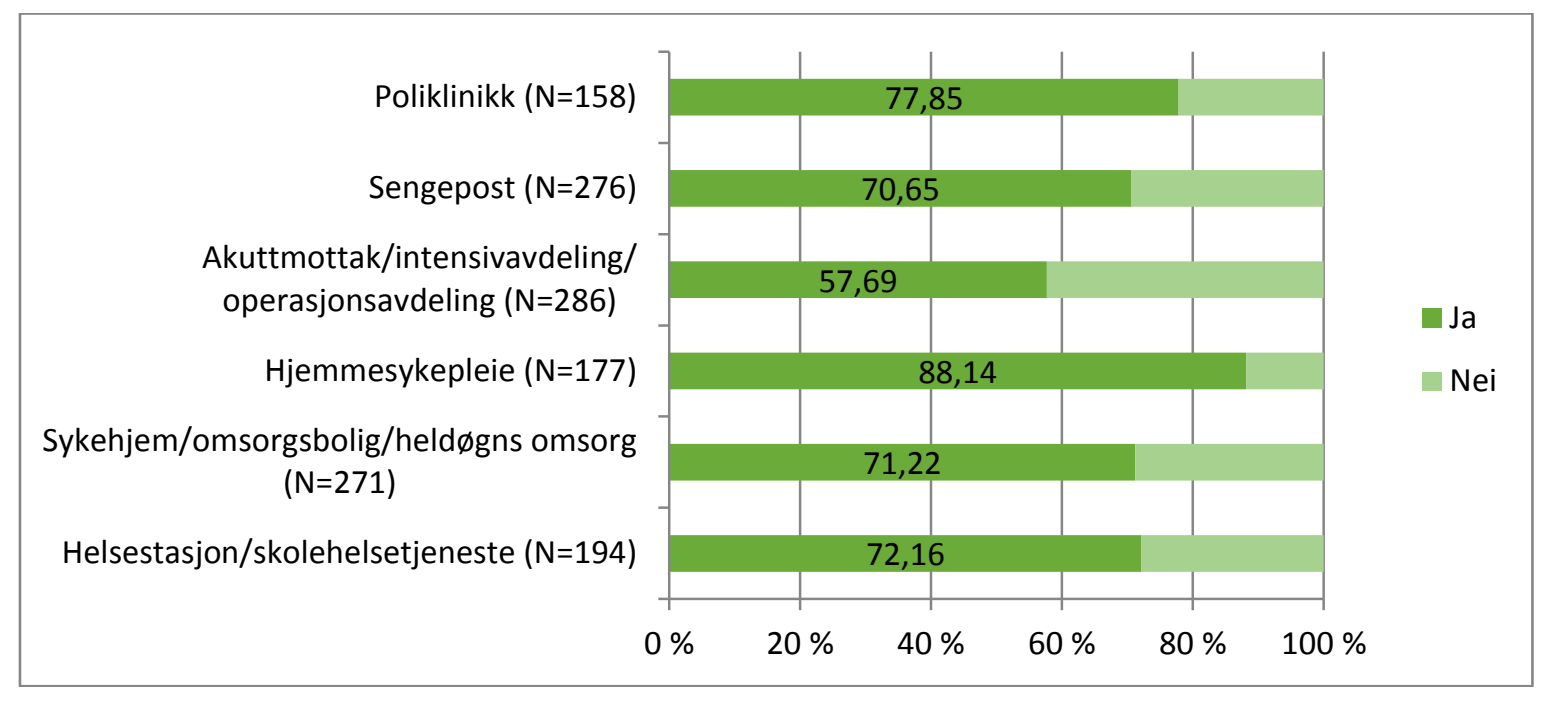

Figur 18 Jobber du sekundærforebyggende (ved helseproblemer)? Prosent, fordelt på tjenestetype. 


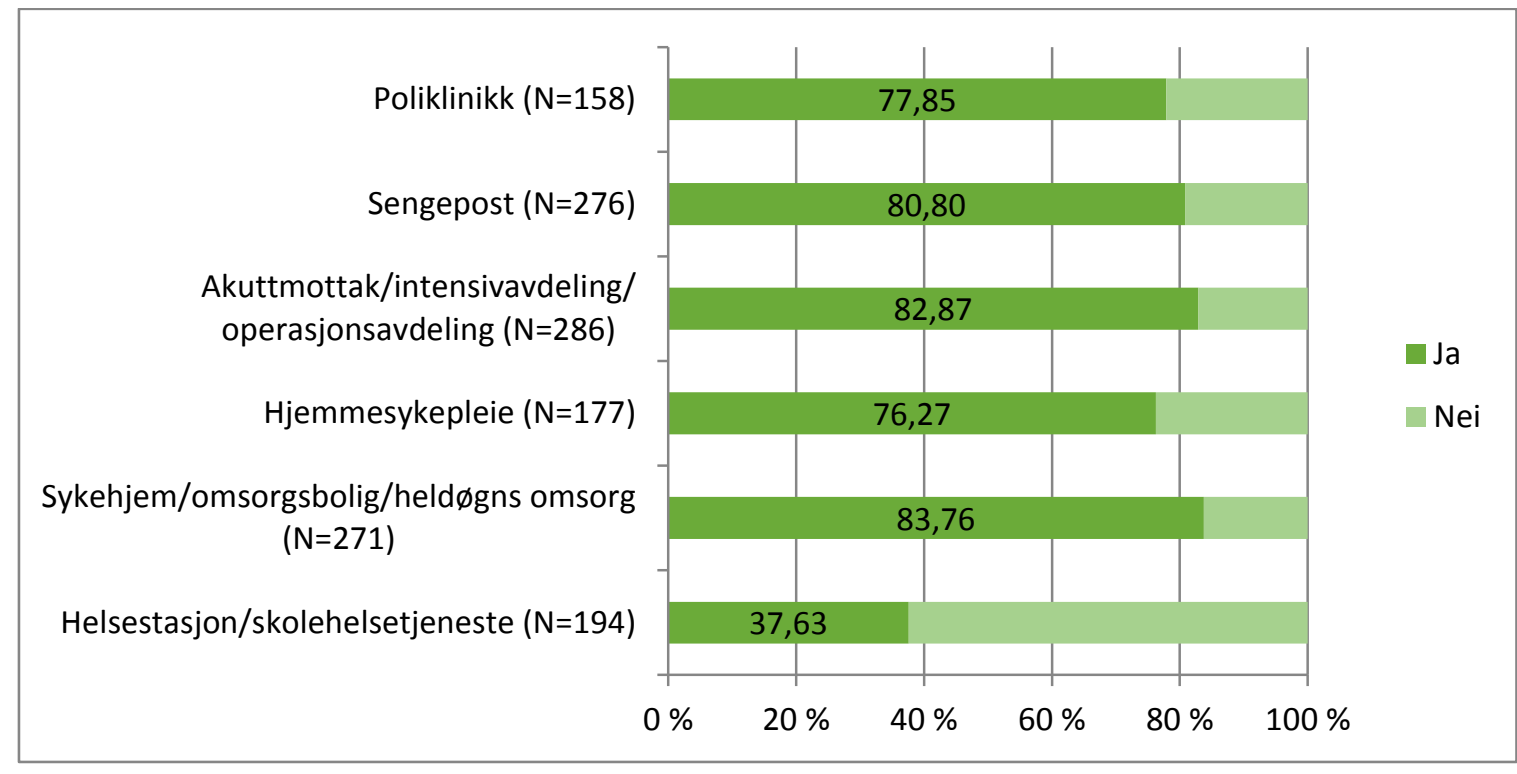

Figur 19 Jobber du tertiærforebyggende (ved etablert skade/sykdom)? Prosent, fordelt på tjenestetype.

Det er ikke overraskende at det er sykepleierne innenfor helsestasjon/skolehelsetjeneste som i størst grad jobber med forebygging generelt. Det ligger i deres mandat (jf. Helse- og omsorgstjenesteloven § 3-2). Det er på denne måten helsestasjoner og skolehelsetjenesten skal jobbe. Det er en tjeneste som skal være tilgjengelig for - og nå ut til - flest mulig (lavterskeltilbud). Slik sett blir det urimelig å sammenligne en del av de andre tjenestene med helsestasjon/skolehelsetjeneste, siden mandat og målgruppe for tjenestene varierer. En kan for eksempel ikke forvente at det skal foregå utstrakt primærforebygging innenfor helseog omsorgstjenester som retter seg mot personer med etablerte helseproblemer (gjelder spesielt for spesialisthelsetjenester som akuttmottak, poliklinikk og sengepost), og som har et konkret behandlingsbehov. Helsetjenestene er til for folk med ulike helseproblemer, og dette vil påvirke måten det jobbes på.

Samtidig er det noen resultater her som indikerer at det er et potensial for å styrke den forebyggende innsatsen. For eksempel ser vi at 36 prosent av sykepleierne innenfor sykehjem/omsorgsbolig/heldøgns omsorg og hjemmesykepleie oppgir at de jobber med primærforebygging. Det betyr at flertallet av sykepleierne innfor disse tjenestene ikke jobber på denne måten. Selv om pasientene som omfattes av disse tjenestene gjerne har etablert sykdom eller helseproblem, så vil perspektivet med primærforebygging fortsatt være relevant, for å forhindre utvikling av andre sykdommer og en generelt dårligere helse. Primærforebygging handler om å forhindre at sykdom og "uhelse" inntreffer, og det er en tilnærming som også vil være relevant for personer som allerede har helseproblemer.

Vi skal nå se nærmere på hvilken type tiltak (innenfor forebyggende arbeid) sykepleierne hovedsakelig jobber med. Vi skiller da mellom universelle, selektive og indikative tiltak. Mens universelle tiltak beskriver tiltak som er rettet mot alle, så rettes selektive tiltak inn mot grupper som er i risiko. Indikative tiltak er enda mer avgrenset, gjennom å rette seg mot grupper med kjent risiko. I en undersøkelse av sykepleieres folkehelsearbeid er det relevant å kartlegge dette, fordi det sier noe om bredden og helheten $\mathrm{i}$ sykepleiernes tilnærming til pasientene. 


\section{(9) SINTEF}

Tabell 12 Antall og andel som jobber med universelle, selektive og indikative tiltak. Hele utvalget.

\begin{tabular}{lcc}
\hline & $\begin{array}{c}\text { Ja, jobber med } \\
\text { (antall) }\end{array}$ & $\begin{array}{c}\text { Andel som jobber } \\
\text { med (prosent) }\end{array}$ \\
\hline Universelle tiltak $(\mathrm{N}=1539)$ & 670 & 43,5 \\
Selektive tiltak $(\mathrm{N}=1539)$ & 728 & 47,3 \\
Indikative tiltak $(\mathrm{N}=1539)$ & 918 & 59,7 \\
\hline
\end{tabular}

Akkurat som for forebygging, så ser vi det også for tiltak er mest vanlig å jobbe med grupper som har kjent risiko for sykdom, og som har sykdom og dårlig helse (spesielt såkalte indikative tiltak). Det er litt mindre vanlig å jobbe med tiltak som retter seg mot alle (universelle tiltak). Forskjellene her er imidlertid mindre enn tilfellet var med de ulike formene for forebygging.

I de tre neste figurene ser vi på samme tema, men inkluderer nå hvilken tjeneste sykepleierne jobber innenfor. Igjen er målet å se om eventuelle variasjoner i bruken av ulike tiltak kan knyttes til tjenestetype:

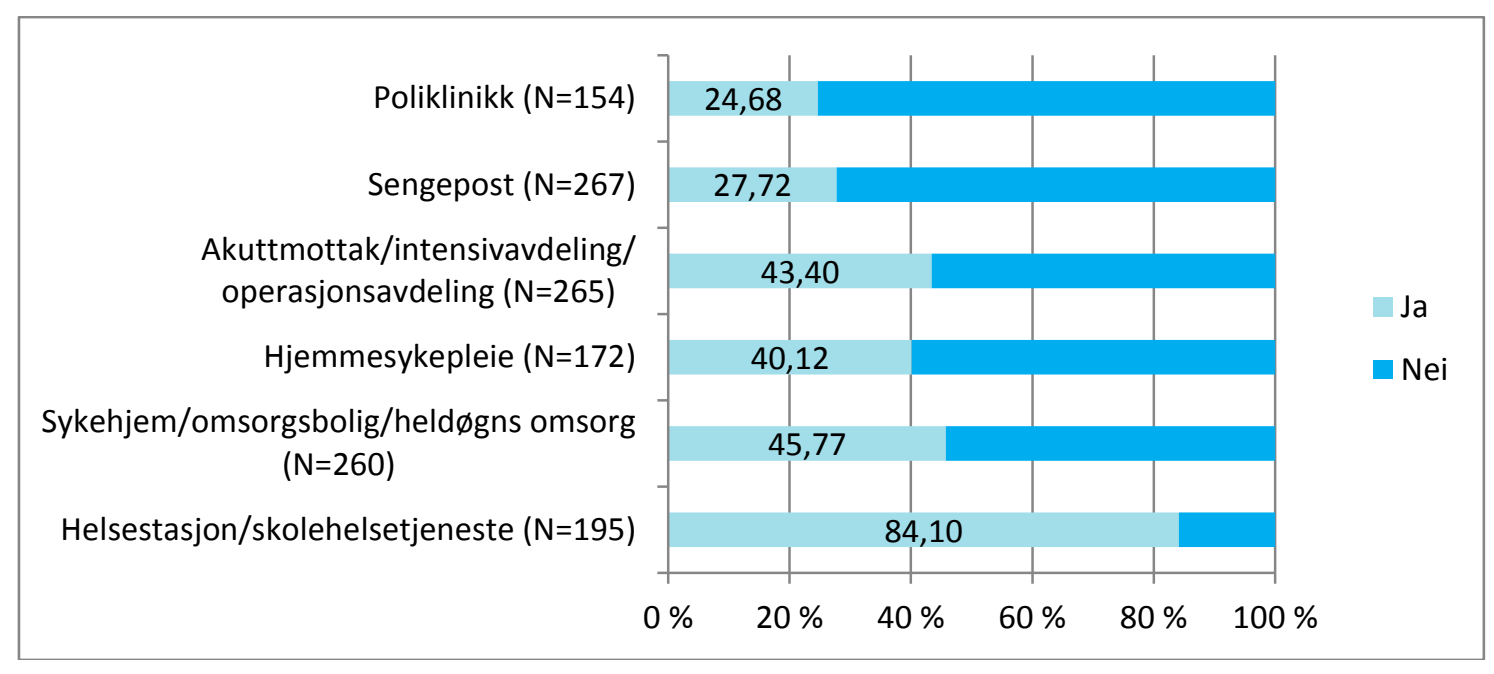

Figur 20 Anvender du universelle tiltak (rettet mot alle)? Fordelt på tjenestetype. 


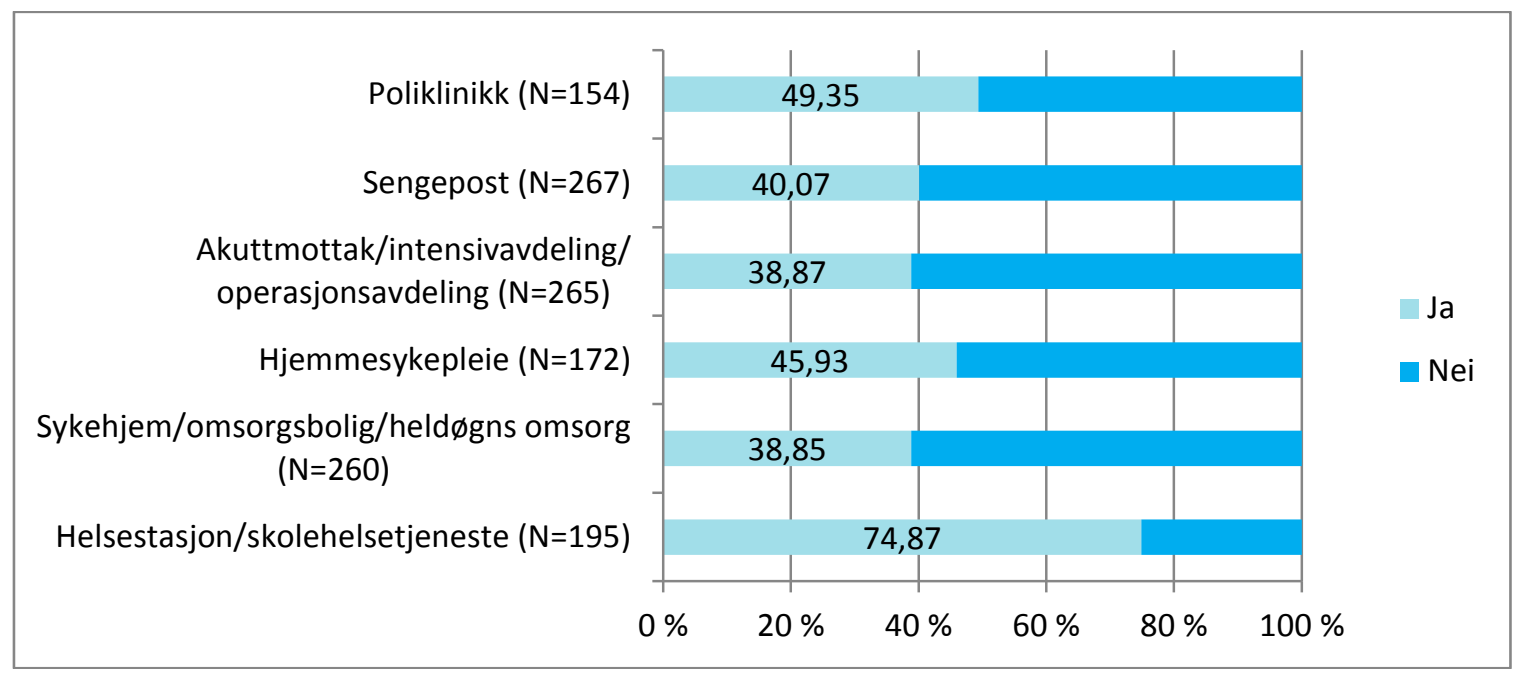

Figur 21 Anvender du selektive tiltak (rettet mot grupper i risiko)? Fordelt på tjenestetype.

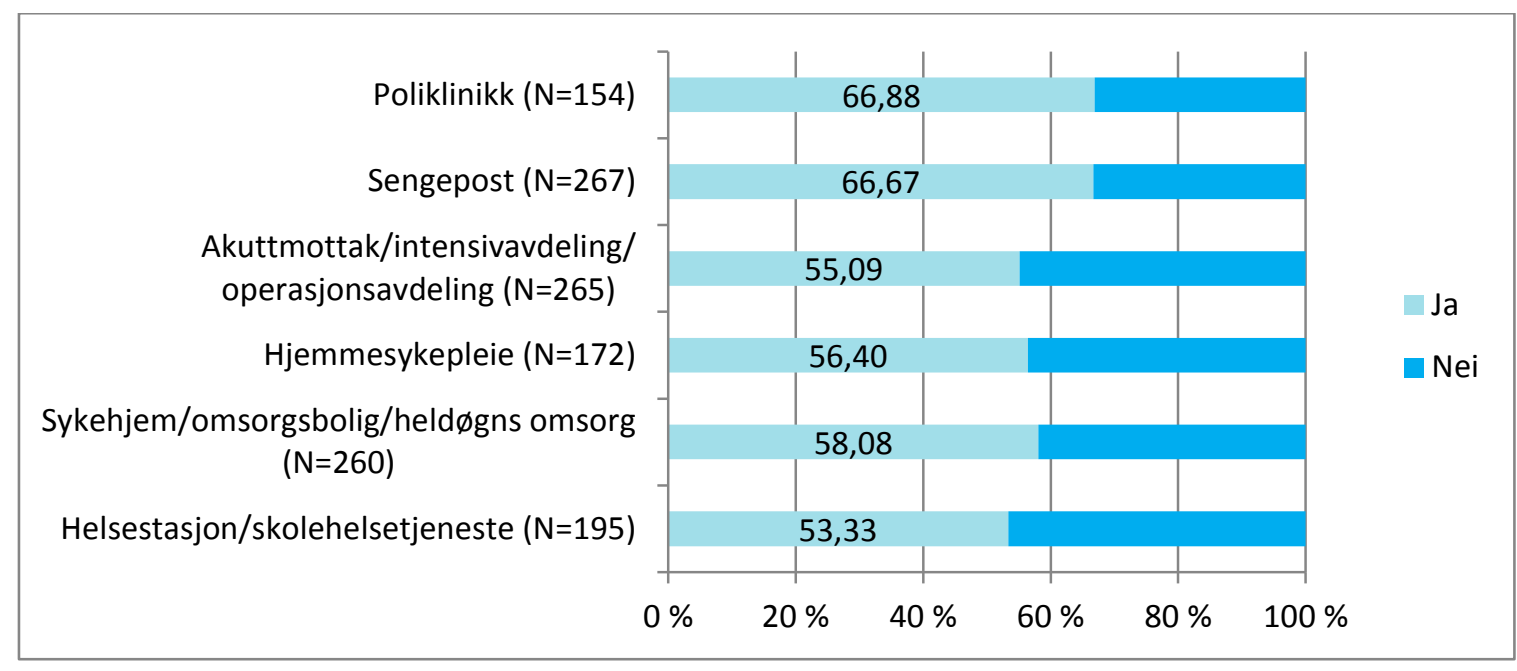

Figur 22 Anvender du indikative tiltak (rettet mot grupper med kjent risiko)? Fordelt på tjenestetype.

Ikke overraskende ser vi at helsestasjon/skolehelsetjeneste nok en gang skiller seg ut; 84 prosent av sykepleierne i denne tjenesten svarer at de hovedsakelig jobber med universelle tiltak (rettet mot alle) innenfor det forebyggende arbeidet. Men også når det gjelder selektive tiltak (rettet mot grupper i risiko) er det sykepleierne som jobber i helsestasjon/skolehelsetjenesten som utmerker seg; 75 prosent, eller tre av fire sykepleiere, bekrefter at dette er tiltak de anvender ofte. Indikative tiltak, i kontrast, er mer vanlig innenfor alle de andre tjenestene. Dette er ikke overraskende, gitt at de andre helsetjenestene typisk har en mer avgrenset pasientgruppe, der sykdom og risiko er mer kjent.

Helsesøstrene som ble intervjuet bekreftet bildet av at de i stor grad jobber med universelle tiltak. En av dem sa det slik: "Vi er jo grunnfjellet, kan du si, og så er det veldig mye over det" (helsesøster, kommune 612). Samtidig pekte en annen av helsesøstrene på at "de universelle tiltakene bortprioriteres til fordel for individuelle tiltak": 
"Vi er veldig mye brukt til individuell oppfølging: elever som sliter, det kan være kriser i hjemmet. Foreldre bruker oss, lærere tar kontakt: "Denne eleven trenger hjelp og så videre". Det blir veldig mye individuelt fokus. Da blir primærforebyggende tilbud som å få oversikt over helsetilstanden; veiing og måling av den enkelte nedprioritert" (Helsesøster, kommune 7)

På grunn av den store etterspørselen etter helsesøstrenes tjenester og manglende ressurser, frykter hun at helsestasjonen og skolehelsetjenestens innsats går i retning av brannslukking heller enn å drive med universelle tiltak. I samsvar med informanten som beskriver helses østrene som grunnfjellet, ønsker hun seg også tilbake til en slik rolle:

"Hvordan skal vi komme tilbake til det primære; den generelle folkeopplysningen? For vi har en veldig klar formening om at det er der vi skal være, og vi skal identifisere barn og unge som trenger hjelp fra andre instanser" (Helsesøster, kommune 7)

Prioriteringen mellom å iverksette og arbeide med individuelle vs. universelle tiltak, kommer vi tilbake til i avsnittet om rammebetingelser. Ellers er det et interessant funn at en st $\varnothing$ rre andel sykepleiere innenfor akuttmottak/intensivavdeling/operasjonsavdeling oppgir å jobbe med universelle tiltak, enn sykepleiere som jobber på sengepost (43,4 mot 27,7 prosent). På sengepost er det mer vanlig å jobbe primært med selektive og indikative tiltak. I og med at pasientgjennomstrømningen er større i førstnevnte tjeneste enn på en sengepost (der en del pasienter ligger lenge inne), så kunne man kanskje forvente at det var omvendt.

Prioriteringen mellom å satse på universelle vs. individuelle og selektive tiltak er et tema og en utfordring som flere av informantene var inne på. Vi avslutter dette avsnittet med et sitat fra en folkehelsekoordinator som satte ord på denne krevende utfordringen slik:

"Når du får to saker, der en brenner, og en kanskje ikke helt ser vitsen med å gi noen penger til den andre [fordi den ikke haster], så er det selvfølgelig å gi penger til der det brenner. Og sånn er jo folkehelse. Hvis du tenker langsiktig: Det å lage et godt uteareal på en skole, versus flere sykehjemsplasser? For det er flere som ikke får plass på sykehjemmet, ikke sant. Det er helt klart at du må ha sykehjemsplasser. Men på lang sikt, så er det jo viktig at elevene kan få røre seg i friminuttene og har det ålreit på skolen, det er kjempeviktig. (...) Så du har jo den [problemstillingen] der hele tiden. Det der er jo et av de største, vanskeligste punktene i forhold til folkehelse, å få bevilget penger til universelle tiltak som når alle. Og så skal du argumentere for hvorfor du skal ha det, versus det andre som brenner" (Folkehelsekoordinator, kommune 1)

\subsection{Rammebetingelser for å jobbe forebyggende og helsefremmende}

Dersom målet er at helsefremmende og forebyggende arbeid skal være en integrert del av helse- og omsorgstjenesten, er det nødvendig å se nærmere på rammebetingelsene på ulike nivåer for å jobbe på denne måten. Med rammebetingelser mener vi faktorer på ulike nivå som legger til rette for å jobbe forebyggende og helsefremmende. Det handler om organisatoriske rammevilkår (tjenesteorganisering, samarbeid og ledelse), фkonomiske og administrative rammevilkår ( $\varnothing$ konomi, budsjett og tid) og ikke minst individuelle rammevilkår (sykepleiernes kompetanse, erfaring og motivasjon for å jobbe forebyggende og helsefremmende). 


\section{(9) SINTEF}

I neste figur presenteres sykepleiernes erfaringer med å jobbe helsefremmende og forebyggende, sett opp mot ledelsens rolle og hvorvidt dette er tema på arbeidsplassen.

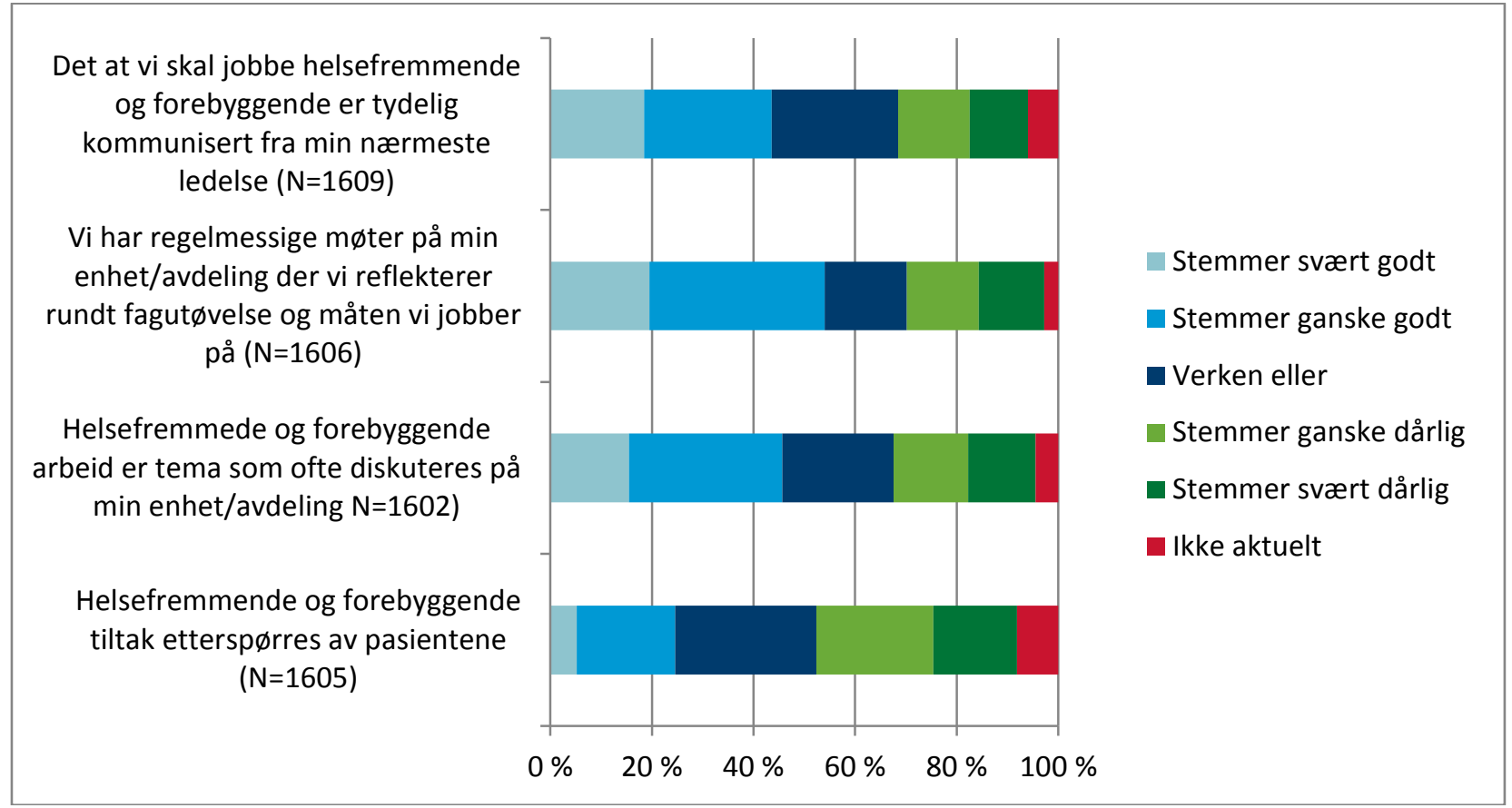

Figur 23 Sykepleiernes opplevelse av rammebetingelser for å jobbe helsefremmende og forebyggende. Antall og prosent.

Andelen som svarer at påstandene stemmer svært godt med situasjonen på deres arbeidsplass, er relativt lav; 18 prosent bekrefter (stemmer svært godt) at det at de skal jobbe helsefremmende og forebyggende, er tydelig kommunisert fra den nærmeste ledelsen. 25 prosent sier at dette er noe som stemmer ganske godt. Blant informantene i intervjuene var det delte oppfatninger om hvorvidt ledelsen kommuniserer at de skal jobbe ut $\mathrm{i}$ fra et helsefremmende og forebyggende perspektiv. Følgende to sitater kan sies å representere ytterpunkter i oppfatningene:

"På vår arbeidsplass synes jeg det er veldig bra, faktisk. Veldig fokus. Vi har en leder som er veldig fokusert på det. Vi er ganske oppbemannet [på grunn av etableringen av en ny avd.], så vi er jo en del folk på. Så vi har en mulighet til å jobbe utadrettet, så det er mye fokus på det, altså" (Psykisk helsevern)

"Det er ikke så mye tid til å prate [om folkehelse]. Det er et problem. Det går så fort. Vi har mer enn nok med å komme oss gjennom dagen og få gjort det vi skal. Så det er dessverre alt for lite tid til å tenke, å se framover og til faglig fordypning" (Psykiatrisk sykepleier, kommune 5)

Som vi ser av sitatene er oppmerksomheten på å jobbe forebyggende/helsefremmende nært forbundet med ressurser. I det første sitatet, fra psykisk helsevern i spesialisthelsetjenesten, viser informanten til at leder gir folkehelseperspektivet mye oppmerksomhet. Siden de i tillegg har nok folk på arbeid, er det mulig å jobbe utadrettet, det vil si å jobbe med pasientene i forkant, før problemene deres $\emptyset$ ker ytterligere. I det andre sitatet forteller en psykiatrisk sykepleier fra kommunen om tidspress og ressursmangel, som gjør det 


\section{(9) SINTEF}

vanskelig å tenke forebygging. Flere resultater $\mathrm{i}$ denne rapporten underbygger inntrykket av at ressursmangel og knapphet på tid gjør det vanskelig å tenke folkehelse i det daglige.

Når det gjelder avdelings- og enhetsmøter som arena for å diskutere helsefremmende og forebyggende arbeid, så bekrefter 19 prosent (stemmer svært godt) at de på sin arbeidsplass har regelmessige møter der de reflekterer rundt fagut øvelse og måten de jobber på. 15,5 prosent svarer det samme til påstanden om hvorvidt helsefremmede og forebyggende arbeid er tema som ofte diskuteres på enheten eller avdelingen. 34,5 og 30 prosent svarte "stemmer ganske godt" til de to påstandene. Alt i alt indikerer tallene at det fortsatt er en del å gå på når det gjelder å forankre folkehelsetematikken rundt omkring på ulike arbeidsplasser.

Videre ser vi at helsefremmende og forebyggende tiltak i liten grad etterspørres av pasientene. Mens det på den ene side må sies å være et lite overraskende resultat, så understreker det samtidig at vurderinger av om hvorvidt man skal prioritere helsefremmende og forebyggende tiltak, ikke bør baseres for mye på pasientenes uttrykte behov og ønsker.

I neste figur presenteres flere påstander om hvordan sykepleierne opplever rammebetingelsene, men med andre svaralternativer:

Vi har organisert tjenestene/tilbudet på en måte som legger til rette for å jobbe forebyggende og helsefremmende $(\mathrm{N}=1562)$

Jeg opplever at min kompetanse på helsefremmende og forebyggende innsats utnyttes på en god måte i dag $(\mathrm{N}=1571)$

På min arbeidsplass er folkehelsearbeidet delegert til bestemte stillinger $(\mathrm{N}=1564)$

Min nærmeste ledelse har lagt til rette for at vi skal kunne jobbe mer forebyggende og helsefremmende overfor pasientene $(\mathrm{N}=1567)$

Min nærmeste ledelse tar folkehelseperspektivet på alvor $\mathrm{N}=1570$ )

Min nærmeste ledelse har god kunnskap om folkehelsearbeid ( $N=1576)$

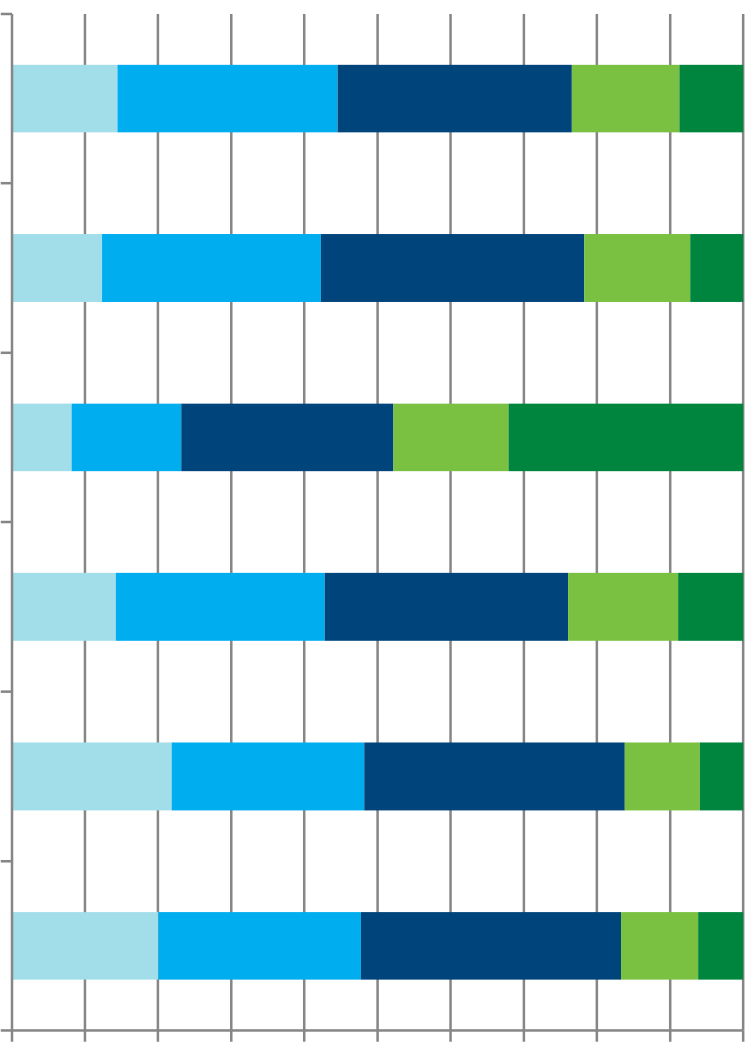

\section{Helt enig Delvis enig \\ verken/ eller \\ Delvis uenig \\ - Helt uenig}

$0 \% 10 \% 20 \% 30 \% 40 \% 50 \% 60 \% 70 \% 80 \% 90 \% 100 \%$

Figur 24 Sykepleiernes opplevelse av rammebetingelser for å jobbe helsefremmende og forebyggende. Antall og prosent. 
Som vi ser av figuren er det en stor andel som svarer delvis enig og verken/eller på de ulike påstandene, noe som skaper et inntrykk av at det er en "viss aktivitet" på folkehelsefeltet, men ikke så veldig stor. Folkehelsearbeidets plass i de ulike tjenestene ser dermed ut til å være litt uavklart. Videre er andelen som svarer at folkehelsearbeidet er delegert til bestemte stillinger relativt lav ( 23 prosent svarer helt eller delvis enig), og kun 12 prosent er helt enig $\mathrm{i}$ at deres kompetanse på helsefremmende og forebyggende innsats blir utnyttet på en god måte. Nær 22 prosent opplever at den ikke utnyttes godt nok (helt og delvis uenig), mens 36 prosent opplever verken det ene eller andre. Resultatet viser at mange arbeidsplasser innenfor helse- og omsorgstjenesten kan ha noe å tjene på å stille seg følgende spørsmål, som et utgangspunkt for diskusjon, endring og forbedring: I hvilken grad klarer vi å utnytte sykepleiernes kompetanse på helsefremmende og forebyggende arbeid?

Når det gjelder påstanden om hvorvidt den nærmeste ledelsen har lagt til rette for at sykepleierne skal kunne jobbe mer forebyggende og helsefremmende, så er 14 prosent helt enig i dette, mens 28,5 prosent er delvis enig. Knapt 22 prosent er helt enig $i$ at ledelsen tar folkehelseperspektivet på alvor, mens 20 prosent er helt enig $i$ at ledelsen ved sin enhet har god kunnskap om folkehelsearbeid. Vi kan ikke se bort fra at ledere likevel har kunnskap om folkehelse, og i større grad ønsker å jobbe med og anvende forebyggende og helsefremmende perspektiver, men at ressursmangel forhindrer at dette blir gjort. Figuren underbygger uansett et inntrykk av at det er en del å gå på før det å jobbe helsefremmende og forebyggende er godt forankret på ledernivå i ulike helsetjenester, og før det manifesterer seg i det konkrete arbeidet som gjøres.

\subsection{Arbeidstidsordning som rammebetingelse for folkehelsearbeidet?}

Arbeidstidsordning kan ses på som en potensiell rammebetingelse for sykepleiernes folkehelsearbeid. For eksempel vil muligheten til å jobbe helsefremmende og forebyggende være forskjellige på natt versus dagtid, fordi "tilgjengeligheten" til pasientene naturlig nok varierer. Forskning har også dokumentert at det er mer belastende og medfører større helserisiko å jobbe natt sammenlignet med dagarbeid (Åkerstedt, 2003), noe som i neste omgang vil kunne påvirke sykepleiernes ressurser, energi og motivasjon for å jobbe helsefremmende og forebyggende.

Tidligere i rapporten presenterte vi tall for arbeidstidsordning blant sykepleierne i utvalget (tabell 8). Tallene viste at et knapt flertall (51 prosent) jobber hovedsakelig dagtid, mens den andre store gruppen består av de som jobber turnus (43,7 prosent). Siden disse to arbeidstidsordningene representerer nær 95 prosent av sykepleierne i utvalget, så er det disse to vi inkluderer i de videre tabellanalysene. Første figur viser svarene på ulike påstander om sykepleiernes erfaringer med å jobbe helsefremmende og forebyggende, fordelt på om de arbeider dagtid eller turnus. 


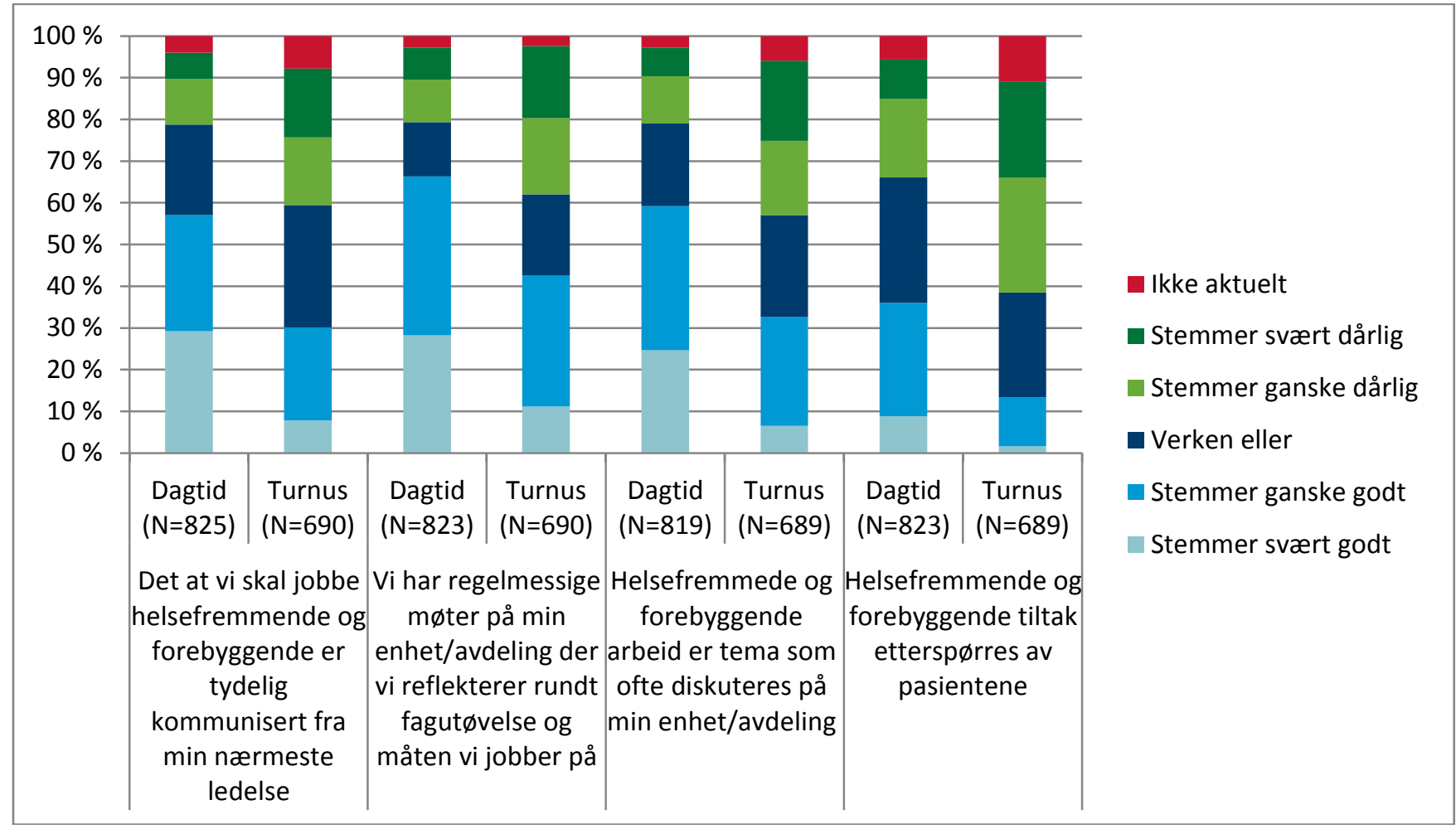

Figur 25 Sykepleiernes opplevelse av rammebetingelser for å jobbe helsefremmende og forebyggende - dagtid versus turnus. Antall og prosent.

Tallene viser klare forskjeller når det gjelder innslaget av helsefremmende og forebyggende arbeid blant sykepleiere som jobber dagtid versus turnus. Forankring hos ledelsen og det å ha folkehelsearbeid som et tema i møter er langt vanligere på arbeidsplasser kjennetegnet av arbeid på dagtid. Arbeidstidsordning ser med andre ord ut til å ha betydning for hvordan sykepleierne opplever at "rommet" for å jobbe helsefremmende og forebyggende er.

I de to neste figurene ser vi på andre påstander som omhandler rammevilkår for å praktisere forebyggende og helsefremmende arbeid, men med vekt på ledelsens rolle og sykepleiernes opplevelse av i hvilken grad deres egen kompetanse på feltet blir utnyttet på en god måte. 


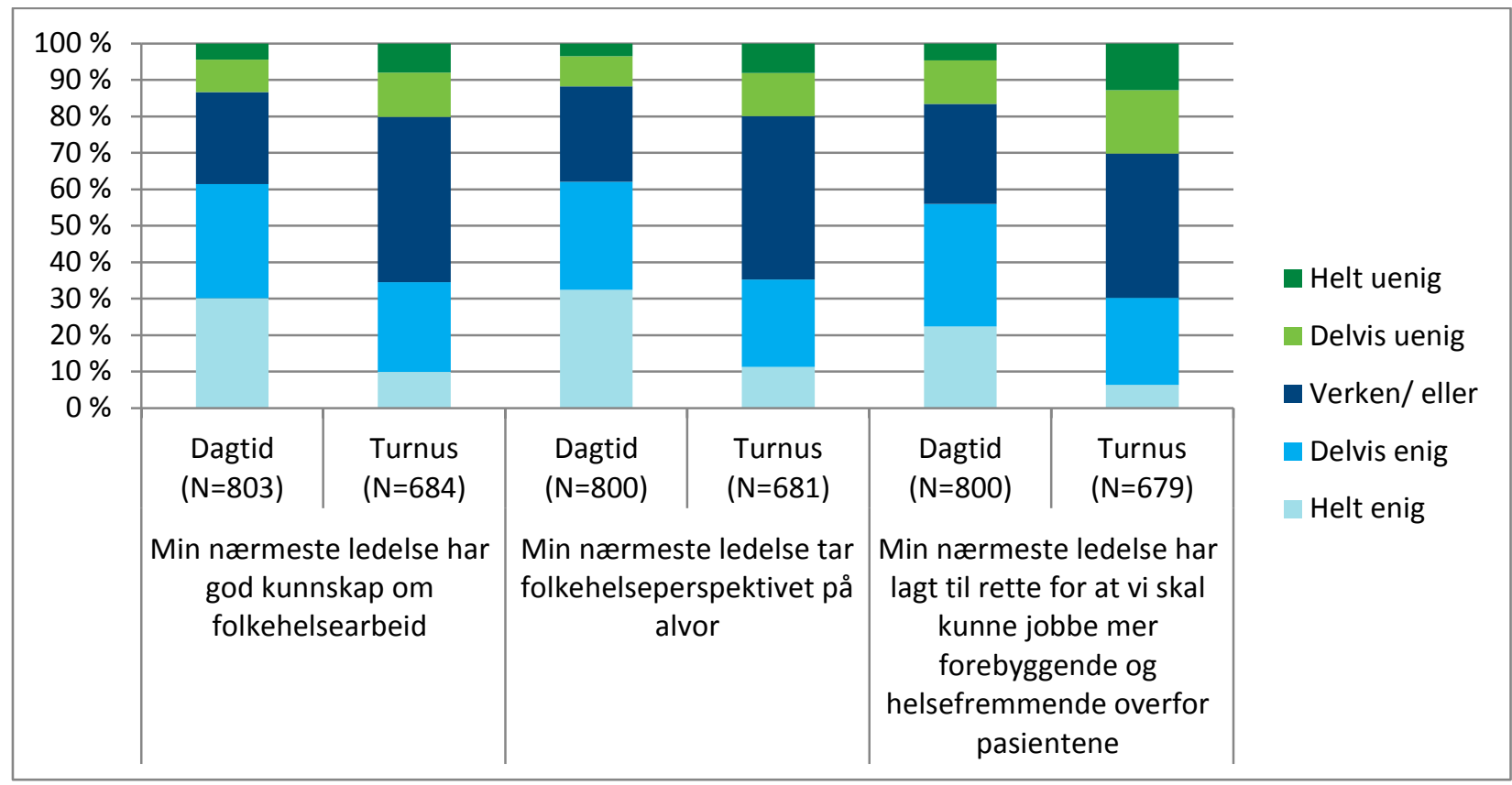

Figur 26 Sykepleiernes opplevelse av rammebetingelser for å jobbe helsefremmende og forebyggende - dagtid versus turnus. Antall og prosent.

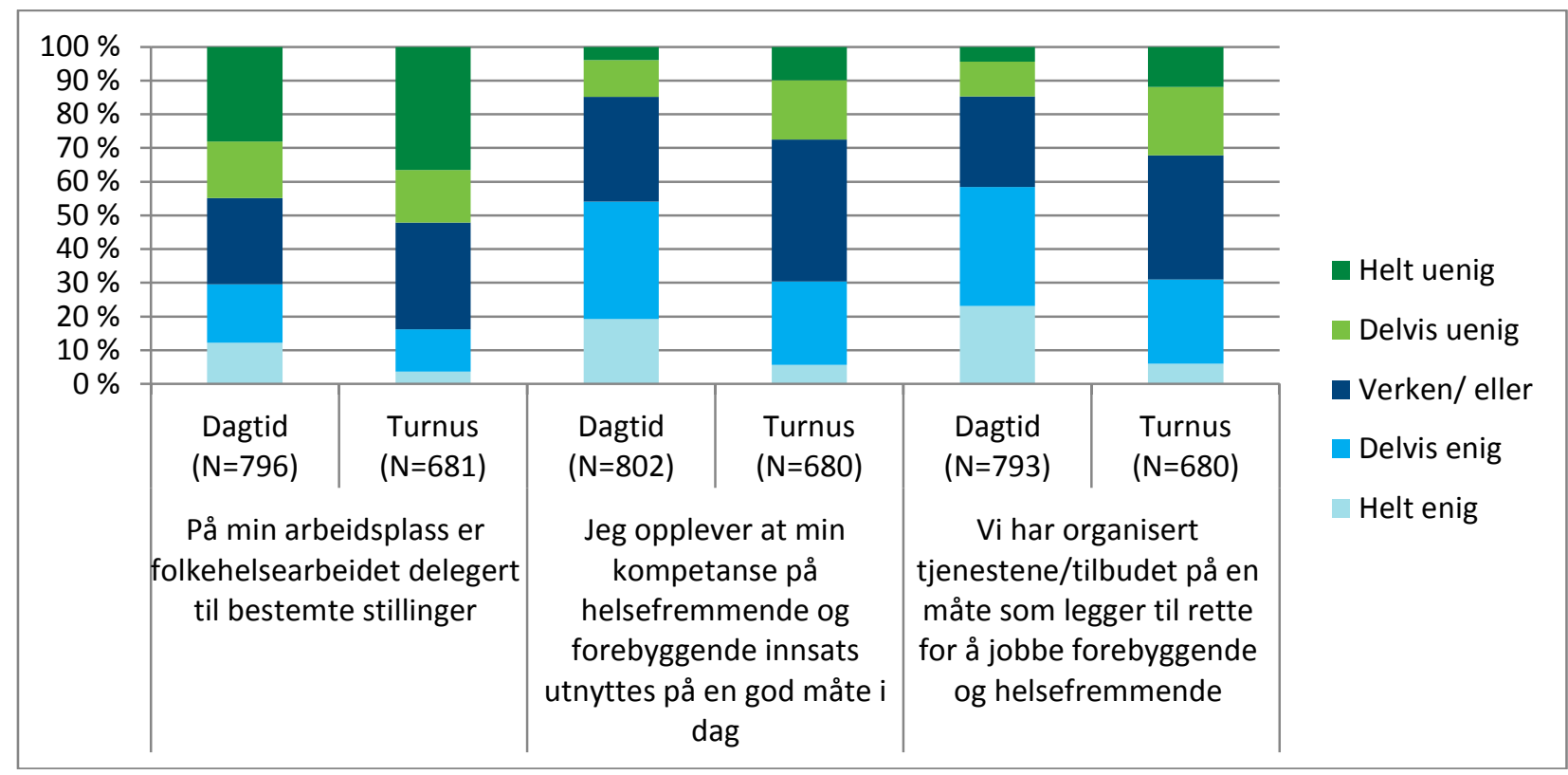

Figur 27 Sykepleiernes opplevelse av rammebetingelser for å jobbe helsefremmende og forebyggende - dagtid versus turnus. Antall og prosent.

Også her ser vi ganske klare forskjeller i tilbakemeldingene mellom sykepleiere som jobber dagtid versus turnus. Andelen som mener at ledelsen har god kunnskap om folkehelsearbeid og tar folkehelseperspektivet på alvor, er betydelig større blant de som jobber dagtid; 61,4 prosent av de som jobber dagtid er helt eller delvis enig i den første påstanden, mens 62 prosent er enig i den andre. Blant sykepleiere som jobber turnus er de tilsvarende andelene henholdsvis 35,5 og 35,2 prosent. Lignende 


\section{(9) SINTEF}

forskjell finner vi for påstanden om at den nærmeste ledelsen har lagt til rette for at de skal kunne jobbe mer forebyggende og helsefremmende overfor pasientene.

Vi kan ikke ut fra dette trekke en slutning om at ledere på arbeidsplasser med turnusordning er mindre opptatt av folkehelsearbeid. Som tidligere drøftet er det noe annet å lede og administrere en turnusarbeidsplass enn en arbeidsplass der det jobbes dagtid, og vi kan ikke se bort fra at dette er noe som har betydning for hvordan helsefremmende og forebyggende arbeid prioriteres. Muligens er det slik at arbeidstidsordningen, mer enn den nærmeste ledelsen, er det som setter rammene for hva som er mulig å få til. Blant sykepleiere som jobber natt vil det dessuten være begrenset hvor mye pasientkontakt de kan ha. Det er også viktig å ha i minne at sykepleierne som jobber i helsestasjons- og skolehelsetjeneste, som er den gruppen som jobber klart mest forebyggende og helsefremmende, vil "dra opp" resultatene for den gruppen som jobber dagtid. Vi kan heller ikke se bort fra at det er en generell forskjell på tid og tilgjengelige ressurser mellom dagarbeid og turnus, og at denne slår inn i våre resultater.

Forskjellen i det vi har kalt rammevilkår for å "utøve" folkehelsearbeid kommer også til syne i figur 27, der vi ser at sykepleiere som jobber dagtid i langt større grad enn sykepleiere som jobber turnus opplever at deres kompetanse på helsefremmende og forebyggende innsats utnyttes på en god måte (henholdsvis 54 mot 30,4 prosent). Videre ser vi at en langt større andel blant de som jobber dagtid mener at de har organisert tjenestetilbudet på en måte som legger til rette for å jobbe forebyggende og helsefremmende, nærmere bestemt 58,4 prosent (mot 31 prosent innenfor turnus).

I neste figur presenterer vi sykepleiernes respons på tre andre påstander om rammevilkår.

Jeg har gode muligheter til å påvirke innholdet i mitt eget arbeid $(\mathrm{N}=1718)$

Ved min enhet kommer vi tidlig i gang med en helsefremmende og forebyggende tilnærming overfor pasientene $(\mathrm{N}=1714)$

Vi har et potensial på min arbeidsplass for å jobbe mer forebyggende og helsefremmende i forhold til de pasientgruppene jeg jobber med ( $N=1729)$

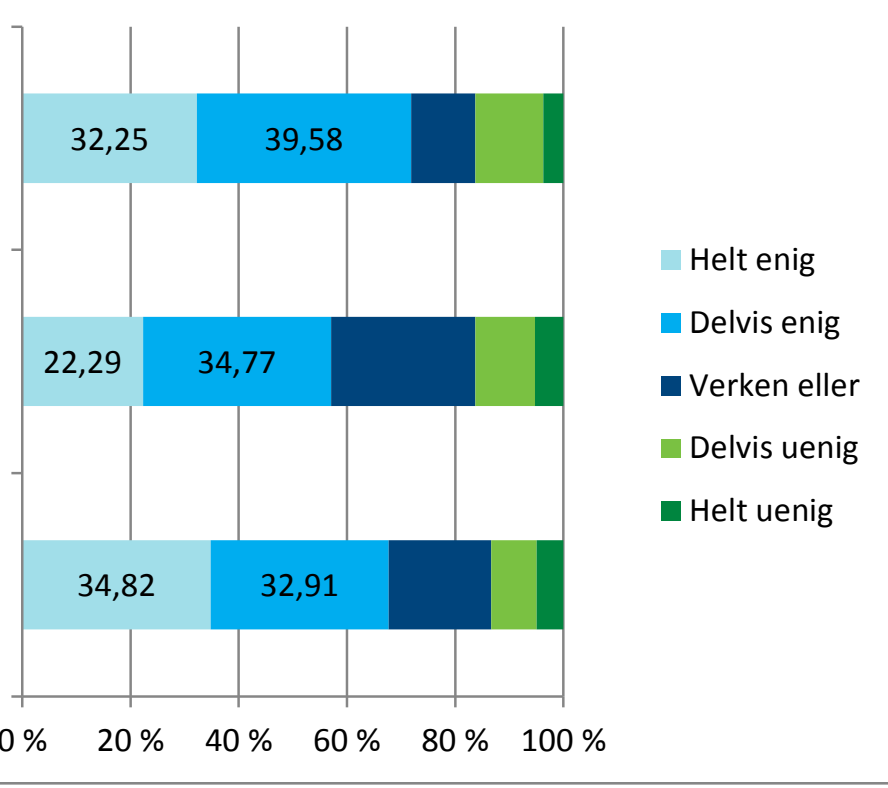

Figur 28 Sykepleiernes opplevelse av rammebetingelser for å jobbe helsefremmende og forebyggende. Prosent, hele utvalget.

72 prosent mener at de har gode muligheter til å påvirke innholdet i sitt eget arbeid (helt eller delvis enig), noe som kan innebære at det for disse i større grad er mulig å inkludere et forebyggende og 


\section{(9) SINTEF}

helsefremmende perspektiv i arbeidet, dersom de ønsker det. 57 prosent er av den oppfatning at de, på sin egen enhet, kommer tidlig i gang med en helsefremmende og forebyggende tilnærming overfor pasientene (helt eller delvis enig). Samtidig mener knapt 68 prosent - altså hele sju av ti sykepleiere - at det er et potensial for å jobbe mer forebyggende og helsefremmende på egen arbeidsplass.

I det følgende ser vi på de samme påstandene, men nå fordelt på hvilken helsetjeneste sykepleierne jobber innenfor. Som tidligere i rapporten differensierer vi på de seks tjenestene med høyest antall respondenter; helsestasjon/skolehelsetjeneste, sykehjem/omsorgsbolig/heldøgns omsorg, hjemmesykepleie (alle kommunale helsetjenester) og akuttmottak/intensivavdeling/operasjonsavdeling, sengepost og poliklinikk (alle spesialisthelsetjenester).

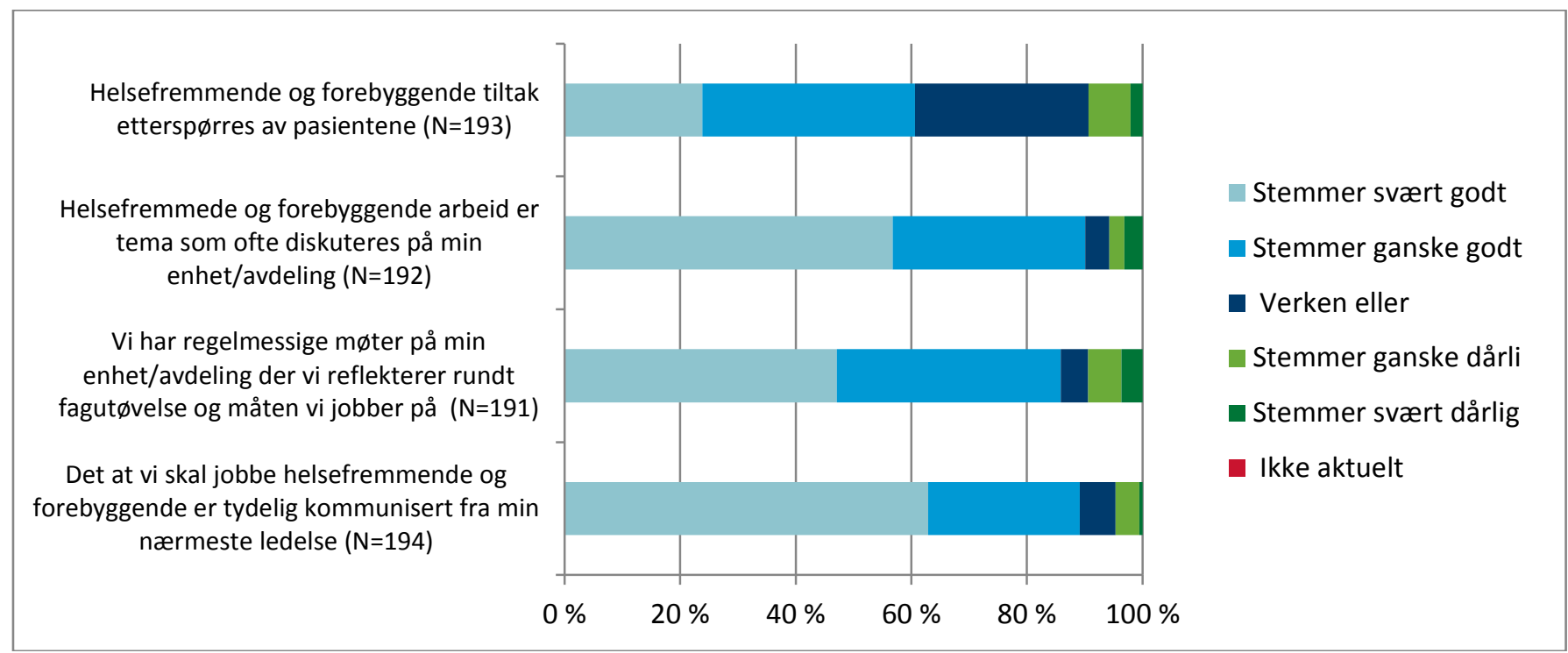

Figur 29 Rammebetingelser for å jobbe helsefremmende og forebyggende - sykepleiere i helsestasjon/ skolehelsetjeneste.

Ser vi først på sykepleiere i helsestasjon/skolehelsetjeneste, så vet vi at dette er en tjeneste som har som sitt samfunnsoppdrag å jobbe forebyggende og helsefremmende overfor hele barne- og ungebefolkningen, primært i form av universelle tiltak. Som vi har sett, kan manglende ressurser og et tilfang av stadig nye arbeidsoppgaver for helsesøstrene gjøre at de universelle tiltakene nedprioriteres til fordel for individuell oppfølging. Figur 29 viser at respondentene som er ansatt i helsestasjoner og skolehelsetjenesten i stor grad opplever at ledelsen kommuniserer at de skal jobbe helsefremmende og forebyggende, og at dette er tema som ofte diskuteres på arbeidsplassen. Figuren gir samtidig færre detaljerte opplysninger om hvordan rammebetingelsene preger arbeidsdagen til helsesøstrene. I intervjuene har dette derimot vært et stort tema. Tidligere i rapporten har vi allerede vært inne på dette, men vi illustrerer hvordan ressursmangel preger tjenestene med ytterligere et par sitater fra to helsesøstre:

"Det [skolehelsetjenesten] er en tjeneste som er sulteforet. Vi har fått styrket med en halv stilling på hver av skolene... Så nå har vi flere skoler i kommunen som har helsesøster i full stilling. Og der blir det et helt annet utgangspunkt for å drive forebyggende. Da blir det ikke bare brannslukking. At helsesøster er på skolen annenhver torsdag mellom 8 og 12 er jo helt umulig for elever å forholde seg til" (Helsesøster, kommune 7) 


\section{(9) SINTEF}

Informanten peker på hvordan økte stillingsandeler er en forutsetning for å drive et godt forebyggende arbeid. I en annen kommune oppleves situasjonen i tjenesten verre:

"[Politikerne] har ikke peiling. De tror alt er på stell, og det er det jo ikke. Vi jobber jo ikke etter nasjonale standarder på bemanning; på antall fødsler per helsesøster, antall barn per skolehelsesøster. Det er jo langt over hva det skal være. Og dette er jo ut i fra en veileder som ble laget før det kom inn en del nye oppgaver (...) Det er jo tverrpolitisk enighet om at tjenesten skal styrkes, så det mangler jo ikke på velvillighet, men de ville ikke øremerke midler" (Helsesøster, kommune 6)

Sitatet tydeliggjør problemet med knappe ressurser i helsestasjon/skolehelsetjeneste, samtidig som tjenestene pålegges et $\varnothing \mathrm{kt}$ antall arbeidsoppgaver. Som informanten peker på har kommunene fått tilført midler fra sentrale myndigheter for å styrke helsesøstertjenesten, men midlene har aldri vært øremerket, noe som har ført til at mange kommuner har brukt midlene på andre tjenester, eller at midlene ennå ikke har blitt benyttet. Dette er både informantenes oppfatning og vises i kartleggingsstudier (Olufsen, Sliper, \& Aune, 2015). ${ }^{3}$

De neste to figurene viser hvordan sykepleiere i sykehjem/omsorgsbolig/heldøgns omsorg og hjemmesykepleie svarte på de samme påstandene.

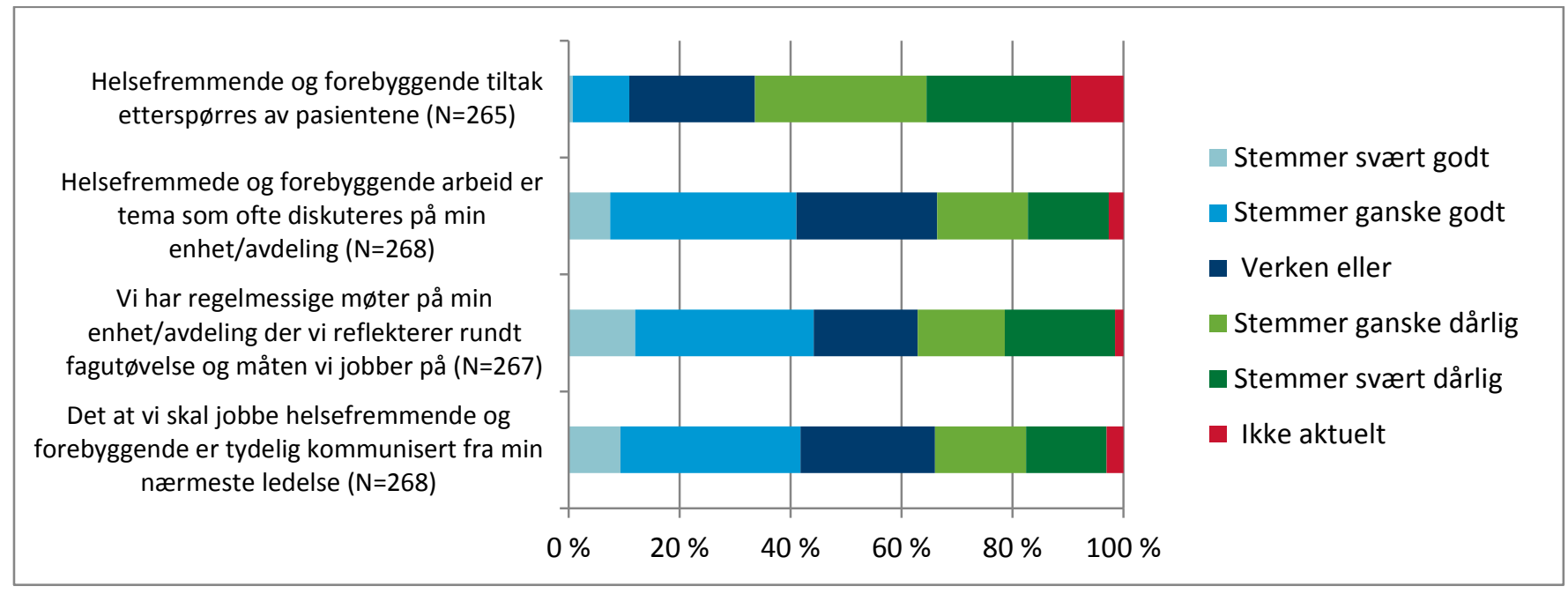

Figur 30 Rammebetingelser for å jobbe helsefremmende og forebyggende - sykepleiere i sykehjem/omsorgsbolig/heldøgns omsorg.

${ }^{3}$ https://sykepleien.no/2014/01/halvparten-gikk-til-helsesostre (lesedato: 20.09.15) 


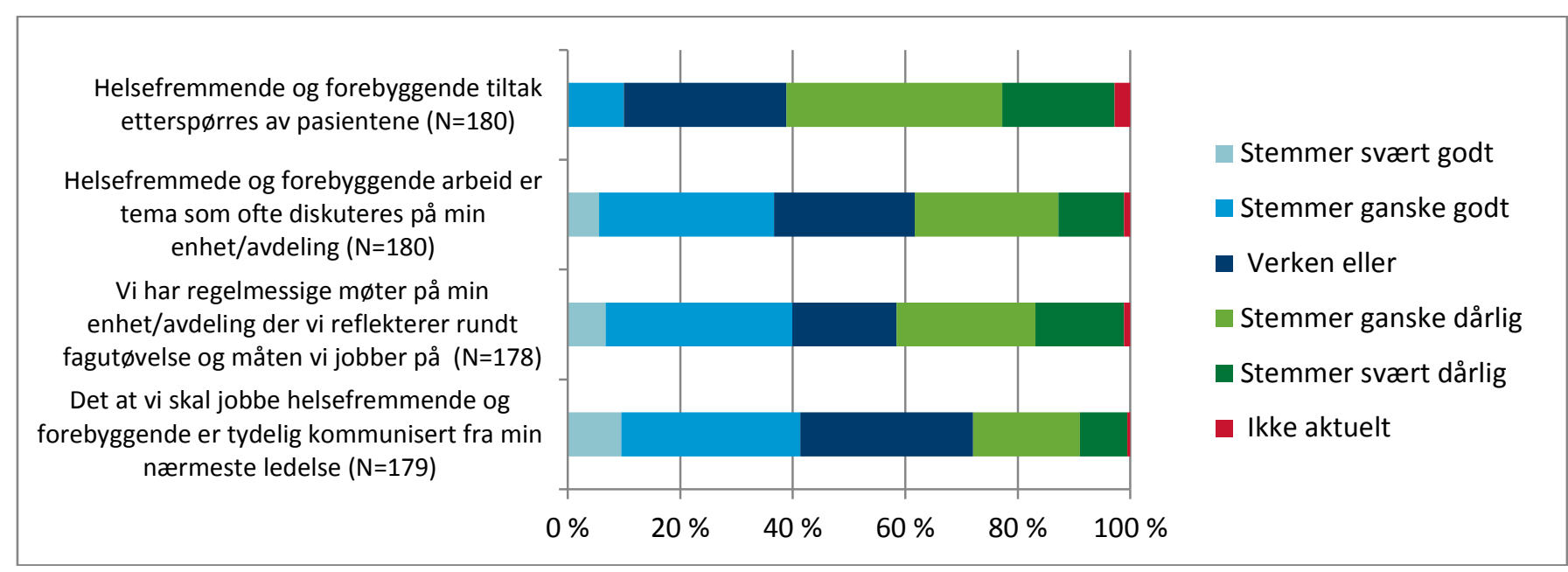

Figur 31 Rammebetingelser for å jobbe helsefremmende og forebyggende - sykepleiere i hjemmesykepleie.

Figur 30 og 31 viser at de to gruppene oppgir ganske like svar. Begge grupper mener i hovedsak at ledelsen har kommunisert tydelig at de skal arbeide forebyggende og helsefremmende. Om lag halvparten av respondentene oppgir at folkehelsetematikken tas opp ved deres enhet, og at de har regelmessige møter der de reflekterer rundt fagut $\varnothing$ velse og hvordan de jobber.

Blant informantene ansatt $\mathrm{i}$ kommunale helse- og omsorgstjenester var det mye snakk om en presset kommuneøkonomi, flere arbeidsoppgaver som skal utføres og kortsiktig problemløsning (brannslukking), framfor den langsiktige forebyggende tankegangen. Sistnevnte kan dessuten være vanskeligere å måle effekten av. Sitatene under illustrerer disse synspunktene:

"Det er ressursmangel og tidspress. Det er rett og slett så mange brukere på hver enkelt. Og så begynner de å bli såpass dårlige etter hvert, de som får tilbud om hjemmesykepleie at... Da jeg startet for mange år siden, så var det sånn at vi hadde tid til å ta en kopp kaffe om morgenen og snakke litt med dem om hvordan dagen hadde vært. Og vi satt ikke lenge (...) i dag er det ikke rom for det" (Hjemmesykepleie, kommune 9)

"Det blir mye brannslukking i kommunen. Vi skal spare penger, vet du. (...) Særlig etter samhandlingsreformen, merker vi det jo" (Psykiatrisk sykepleier, kommune 5)

"Jeg synes det er alt for mye medikamentbruk. Jeg synes vi tenker kortsiktige løsninger og bare pøser på. Så lager vi nye problemer. Å sette eldre på det [benzodiazepiner], så blir de avhengige, og så får de et nytt problem. I stedet for å tenke mer langsiktig - mer folk som kan støtte og være der, å bruke tid. Det blir mer og mer, vi springer fortere. Og det blir kortere tid hos hver enkelt" (Psykiatrisk sykepleier, kommune 5)

Et annet perspektiv som ble løftet fram av informanter som jobbet i hjemmesykepleien, handlet om pasientenes forventinger til tjenestetilbudet og til hjemmesykepleietjenesten. I lys av funnene fra spørreundersøkelsen, som viser at svært få pasienter etterspør helsefremmende og forebyggende tiltak (figur 23), er disse refleksjonene verdt å ta med: 
"I hjemmesykepleien blir kanskje utfordringen... i dagens samfunn er det ganske mye fokus på å kreve ting. Å forvente ting fra det offentlige, å forvente tjenester. Så da er det faktisk en utfordring å ha den filosofien at du skal prøve å begrense det, fordi det er bra for dem [brukerne]. At de skal gjøre ting selv. At jeg sier: "Det kan du prøve å gjøre selv, det er bra for deg, men det er ikke sånn du opplever det". Det er en utfordring i dagens samfunn altså. For vi har en veldig kravmentalitet, og media er jo også flinke til å fortelle hva du har krav på" (Hjemmesykepleie, kommune 2)

"Det er litt en sånn kultur - og det hører jeg jo fra mine egne kolleger også - at får du hjemmesykepleie, da "legger du deg litt bakpå". Da får du gjort ting for deg. Så det blir nok en ganske stor kulturendring i årene som kommer, i og med at hjemmesykepleien ikke er det det en gang var" (Hjemmesykepleie, kommune 9)

Informantenes utsagn viser at det å mobilisere pasientene til større egenaktivitet kan være utfordrende. En hypotese kan være at brukere og pårørende av hjemmesykepleie - kanskje også andre helse- og omsorgstjenester - kan ha en forventing om at når en mottar slike tjenester, så løftes mye av ansvaret for egen helse bort fra en selv og over til helsepersonellet. Sett fra et folkehelseperspektiv vil dette være uheldig. Vi kan se på den store satsingen på hverdagsrehabilitering som en reaksjon på slike strømninger i befolkningen, der verdien av aktivitet og egenomsorg løftes fram.

Vi har også sett på hvordan svarene på de samme spørsmålene fordelte seg blant sykepleiere som jobber innenfor de tre spesialisthelsetjenestene som vi har sett på tidligere i rapporten. Resultatene viste at sykepleiere som arbeider på sengepost og i poliklinikk vurderer situasjonen ganske likt med dem som jobber innenfor sykehjem/omsorgsbolig/heldøgns omsorg samt hjemmesykepleie. Både når det gjelder vurderinger av hvorvidt helsefremmende og forebyggende arbeid er tema som diskuteres på arbeidsplassen, og forankringen av en slik arbeidsmetodikk hos ledelsen, så er vurderingene relativt like i de tre gruppene. Sykepleierne innenfor akuttmottak/intensivavdeling/operasjonsavdeling oppgir imidlertid i mindre grad at det er tydelig kommunisert fra ledelsen at de skal jobbe helsefremmende og forebyggende. De oppgir også i mindre grad at helsefremmede og forebyggende arbeid er tema som ofte diskuteres på deres enhet/avdeling. Det ser videre ut til at pasienter innenfor akuttmottak/intensivavdeling/operasjonsavdeling etterspør denne typen tiltak sjeldnere enn pasienter innenfor de andre tjenestene (både kommune- og spesialisthelsetjenesten). Gitt det vi har skrevet tidligere i rapporten om tjenesteinnhold og pasientgruppe, så er det ikke overraskende at akuttmottak/intensivavdeling/operasjonsavdeling skiller seg ut på denne måten. Andelen som svarer "ikke aktuelt" på spørsmålene er dessuten høyere i denne gruppen. For eksempel svarer 22,6 prosent "ikke aktuelt" på påstanden om at helsefremmende og forebyggende tiltak er noe som etterspørres av pasientene, mens 18 prosent svarer det samme på påstanden om hvorvidt prioritering av helsefremmende og forebyggende arbeid er tydelig kommunisert fra den nærmeste ledelsen.

Det som ellers er interessant er at andelen som oppgir at de har regelmessige møter på sin enhet/avdeling der de reflekterer rundt fagutøvelse og måten de jobber på, er høyere blant sykepleiere som jobber $\mathrm{i}$ poliklinikk og på sengepost (henholdsvis 48 og 52 prosent som svarer stemmer svært godt eller ganske godt), enn tilfellet er blant sykepleiere som jobber innenfor sykehjem/omsorgsbolig/held øgns omsorg eller hjemmesykepleie (henholdsvis 48 og 40 prosent som svarer stemmer "svært godt" eller "ganske godt"). 
Vi ser nå nærmere på noen andre påstander om samme tema, men med andre svaralternativer. Også her skiller vi på tjenestetype.

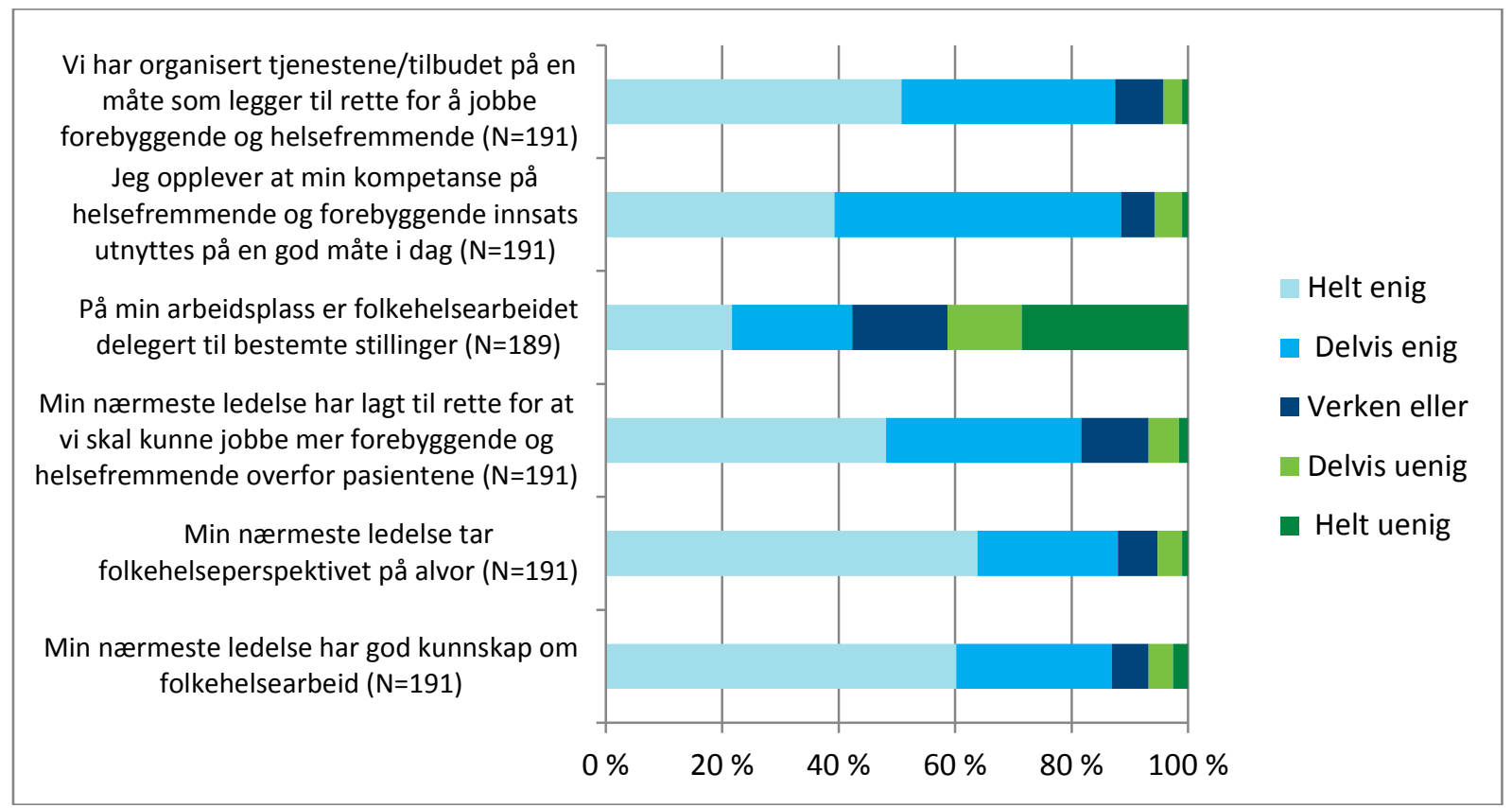

Figur 32 Rammebetingelser for å jobbe helsefremmende og forebyggende - sykepleiere i helsestasjon/skolehelsetjeneste.

Vi har organisert tjenestene/tilbudet på en måte som legger til rette for å jobbe forebyggende og helsefremmende $(\mathrm{N}=261)$

Jeg opplever at min kompetanse på helsefremmende og forebyggende innsats utnyttes på en god måte i dag ( $\mathrm{N}=263)$

På min arbeidsplass er folkehelsearbeidet delegert til bestemte stillinger $(\mathrm{N}=262)$

Min nærmeste ledelse har lagt til rette for at vi skal kunne jobbe mer forebyggende og helsefremmende overfor pasientene $(\mathrm{N}=262)$

Min nærmeste ledelse tar folkehelseperspektivet på alvor ( $N=264)$

Min nærmeste ledelse har god kunnskap om folkehelsearbeid ( $N=264)$

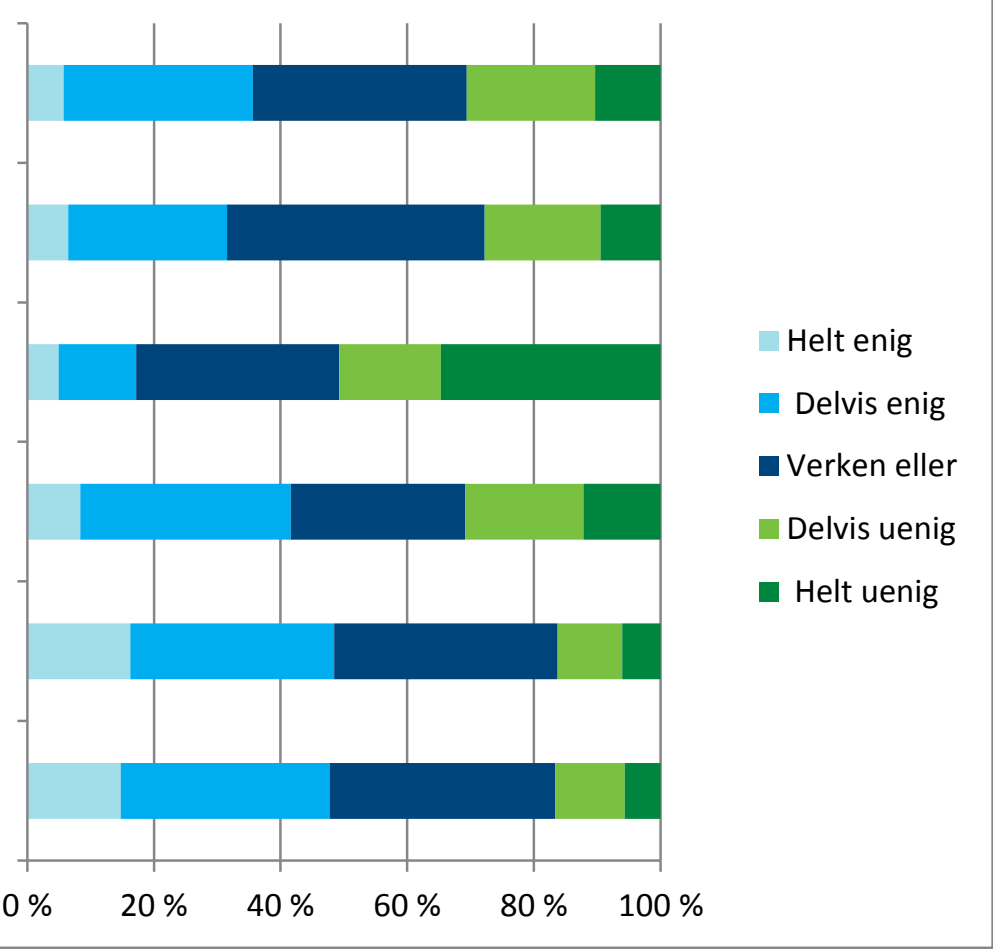

Figur 33 Rammebetingelser for å jobbe helsefremmende og forebyggende - sykepleiere i sykehjem/omsorgsbolig/heldøgns omsorg. 
Vi har organisert tjenestene/tilbudet på en måte som legger til rette for å jobbe

forebyggende og helsefremmende $(\mathrm{N}=172)$ Jeg opplever at min kompetanse på helsefremmende og forebyggende innsats utnyttes på en god måte i dag $(\mathrm{N}=171)$

På min arbeidsplass er folkehelsearbeidet delegert til bestemte stillinger ( $N=173)$

Min nærmeste ledelse har lagt til rette for at vi skal kunne jobbe mer forebyggende og helsefremmende overfor pasientene $(\mathrm{N}=172)$

Min nærmeste ledelse tar folkehelseperspektivet på alvor ( $N=174)$

Min nærmeste ledelse har god kunnskap om folkehelsearbeid ( $\mathrm{N}=174$ )

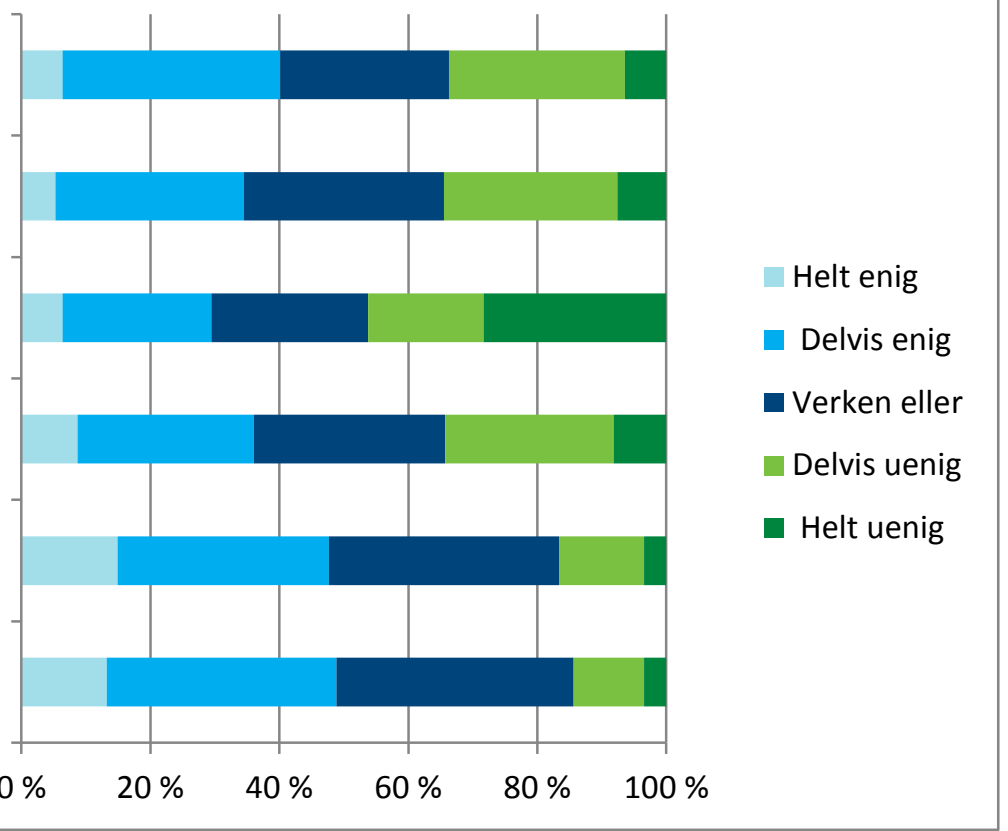

Figur 34 Rammebetingelser for å jobbe helsefremmende og forebyggende - sykepleiere i hjemmesykepleie.

Vi har organisert tjenestene/tilbudet på en måte som legger til rette for å jobbe

forebyggende og helsefremmende $(\mathrm{N}=286)$ Jeg opplever at min kompetanse på helsefremmende og forebyggende innsats utnyttes på en god måte i dag $(\mathrm{N}=288)$

På min arbeidsplass er folkehelsearbeidet delegert til bestemte stillinger $(\mathrm{N}=284)$

Min nærmeste ledelse har lagt til rette for at vi skal kunne jobbe mer forebyggende og helsefremmende overfor pasientene $(N=283)$

Min nærmeste ledelse tar

folkehelseperspektivet på alvor $(\mathrm{N}=284)$

Min nærmeste ledelse har god kunnskap om folkehelsearbeid $(\mathrm{N}=288)$

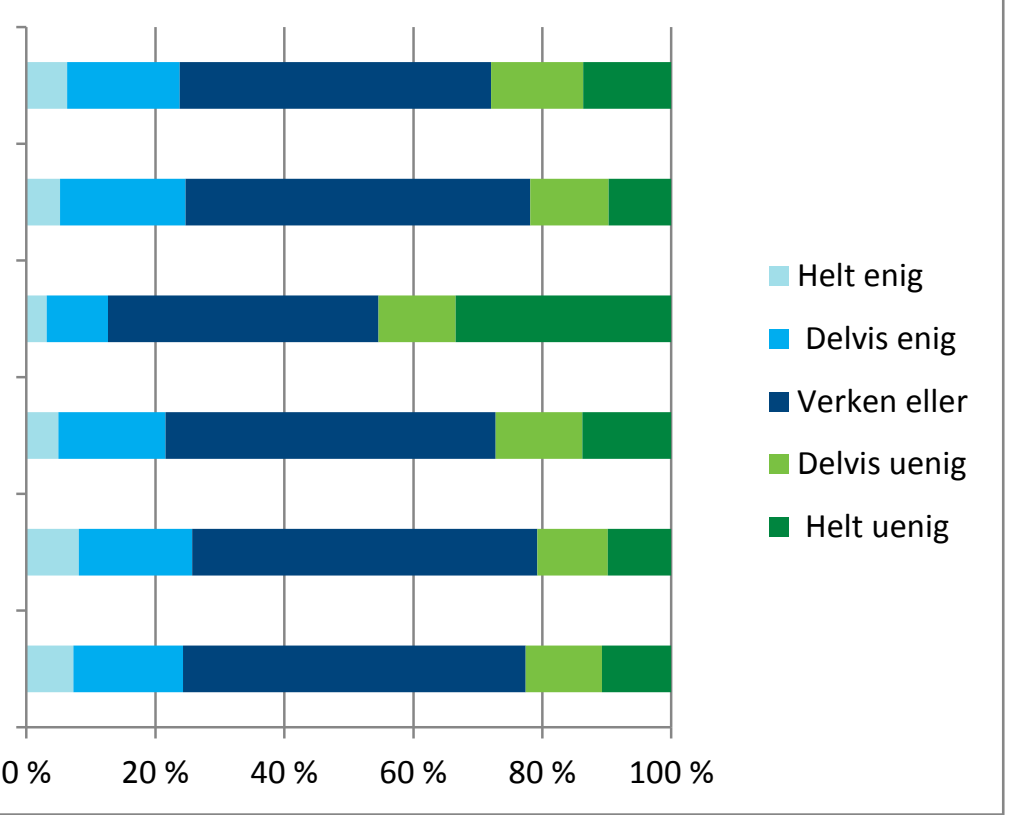

Figur 35 Rammebetingelser for å jobbe helsefremmende og forebyggende - sykepleiere i akuttmottak/intensivavdeling/operasjonsavdeling. 
Vi har organisert tjenestene/tilbudet på en måte som legger til rette for å jobbe

forebyggende og helsefremmende $(\mathrm{N}=262)$ Jeg opplever at min kompetanse på helsefremmende og forebyggende innsats utnyttes på en god måte i dag $(\mathrm{N}=265)$

På min arbeidsplass er folkehelsearbeidet delegert til bestemte stillinger $(\mathrm{N}=265)$

Min nærmeste ledelse har lagt til rette for at vi

skal kunne jobbe mer forebyggende og helsefremmende overfor pasientene $(\mathrm{N}=265)$

Min nærmeste ledelse tar

folkehelseperspektivet på alvor ( $N=266)$

Min nærmeste ledelse har god kunnskap om folkehelsearbeid ( $N=266$ )

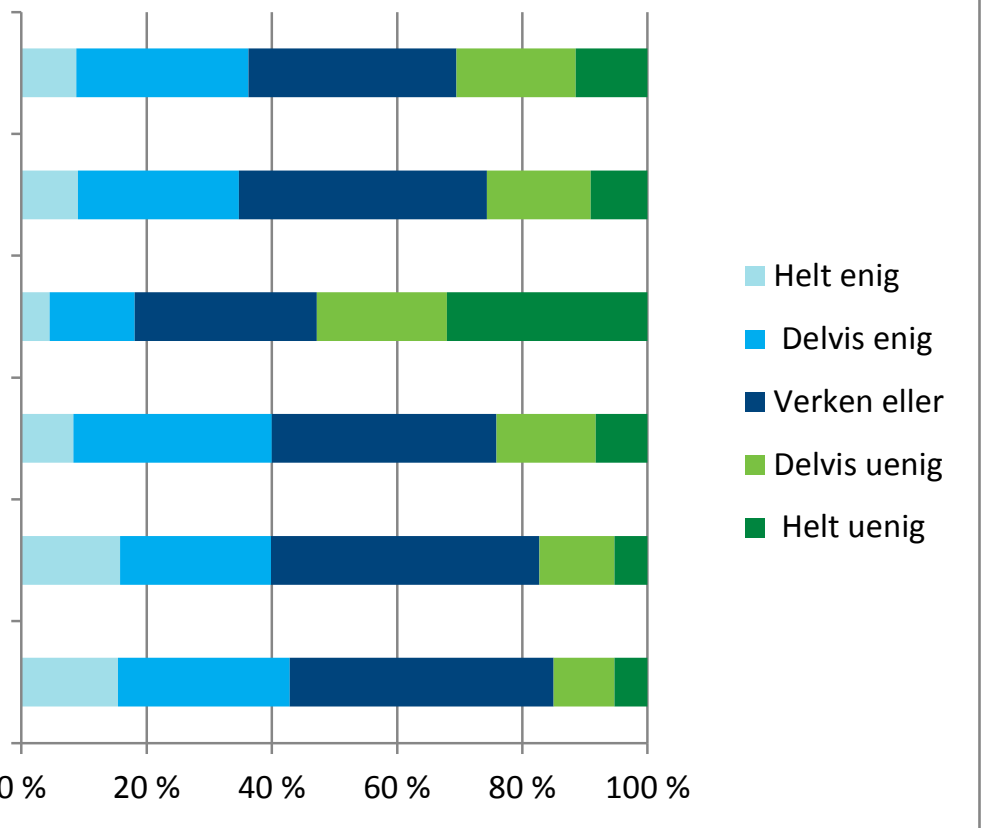

Figur 36 Rammebetingelser for å jobbe helsefremmende og forebyggende - sykepleiere på sengepost.

Vi har organisert tjenestene/tilbudet på en måte som legger til rette for å jobbe

forebyggende og helsefremmende ( $\mathrm{N}=149)$ Jeg opplever at min kompetanse på helsefremmende og forebyggende innsats utnyttes på en god måte i dag $(\mathrm{N}=152)$

På min arbeidsplass er folkehelsearbeidet delegert til bestemte stillinger $(N=152)$

Min nærmeste ledelse har lagt til rette for at vi skal kunne jobbe mer forebyggende og helsefremmende overfor pasientene $(\mathrm{N}=153$ )

Min nærmeste ledelse tar folkehelseperspektivet på alvor $(\mathrm{N}=152)$

Min nærmeste ledelse har god kunnskap om folkehelsearbeid ( $\mathrm{N}=153)$

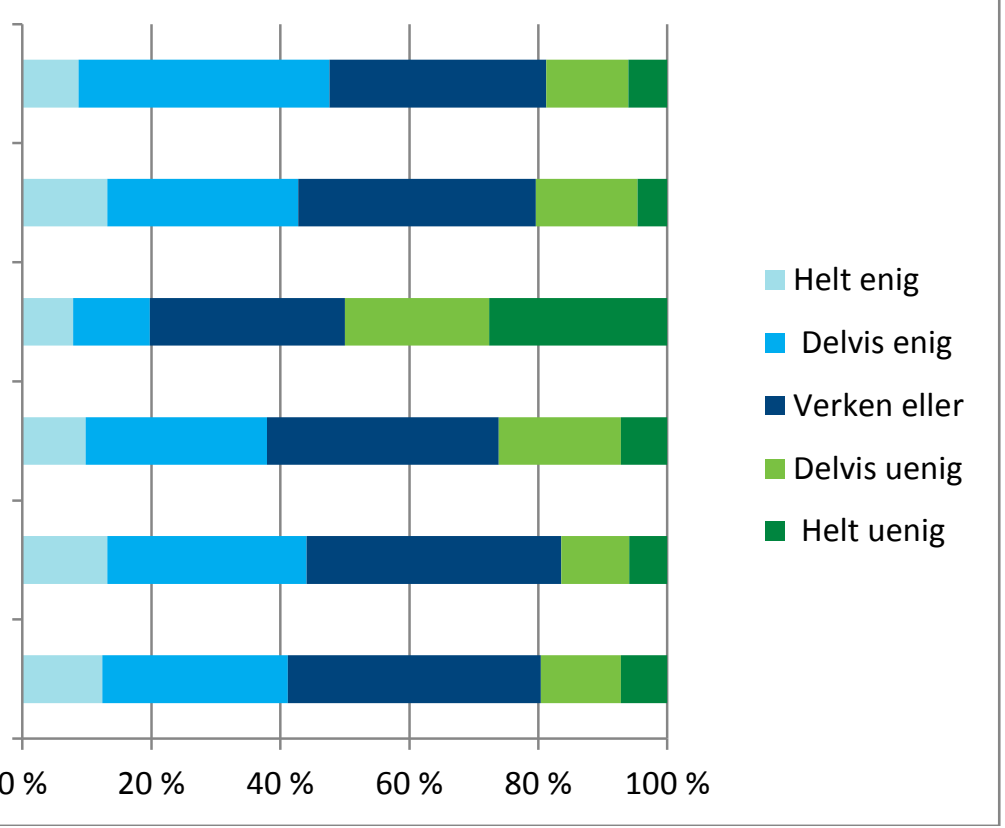

Figur 37 Rammebetingelser for å jobbe helsefremmende og forebyggende - sykepleiere i poliklinikk.

Figurene viser en viss forskjell på tvers av tjenestene når det gjelder hvordan rammevilkårene for å jobbe forebyggende og helsefremmende oppleves. Som vi har drøftet andre steder vil en naturlig forklaring på dette være at tjenestene varierer med tanke på formål, innhold og målgrupper. Dermed er det naturlig at helsefremmende og forebyggende arbeid også vektlegges og prioriteres ulikt. Spørsmålet blir likevel om de 


\section{(9) SINTEF}

forskjellene vi observerer på en del påstander er "unødvendig" store, i den forstand at man kunne gjort mer på det forebyggende og helsefremmende området $\mathrm{i}$ en del tjenester.

Andelen sykepleiere som opplever at de har organisert tjenestetilbudet på en måte som legger til rette for å jobbe forebyggende og helsefremmende, varierer på tvers av tjenester. 36 prosent innenfor sykehjem/omsorgsbolig/heldøgns omsorg er av en slik oppfatning (kun 5,75 prosent som svarer helt enig), mens andelen innenfor hjemmesykepleie er på 40 prosent (6,4 prosent helt enig). Tilsvarende andel innenfor akuttmottak/intensivavdeling/operasjonsavdeling er 24 prosent (6,3 prosent helt enig), og 36 prosent blant sykepleiere som jobber ved sengepost. Bildet er mer positivt blant de som jobber ved poliklinikk; her svarer nesten 48 prosent at organiseringen ligger til rette for å jobbe forebyggende og helsefremmende. Nok en gang skiller helsestasjon/skolehelsetjeneste seg ut; her sier 87,5 prosent seg enig (50,8 prosent helt enig). Figurene understøtter dermed inntrykket av at tjenestetype, tjenesteinnhold og målgruppe ser ut til å fungere som et viktig rammevilkår i seg selv, gjennom å sette noen rammer for hva som er mulig å få til når det gjelder folkehelsearbeid.

\subsection{Samarbeid med andre aktører i folkehelsearbeidet}

Vi har ulike steder i rapporten omtalt folkehelsearbeid som et stort og dels uoversiktlig felt. Folkehelse er summen av en rekke ulike forhold i samfunnet, som for eksempel levevaner, skole/utdanning, helse, rusbruk, sysselsetting, familiesituasjon, nettverk og økonomi, for å nevne noe. I og med at det er ulike etater og instanser som vil ha ansvaret for det som skjer på disse områdene, så er det innlysende at samarbeid og koordinering vil være nødvendig for å oppnå en systematisk og helhetlig folkehelseinnsats $\mathrm{i}$ samfunnet. Dette vil også være tilfelle innenfor helsetjenesten, der sykepleierne møter pasienter som trenger oppfølging og bistand på flere områder. Vi fant det derfor interessant å kartlegge graden av samarbeid med andre aktører, både i og utenfor helsetjenesten. Neste figur viser hva sykepleierne svarte. 


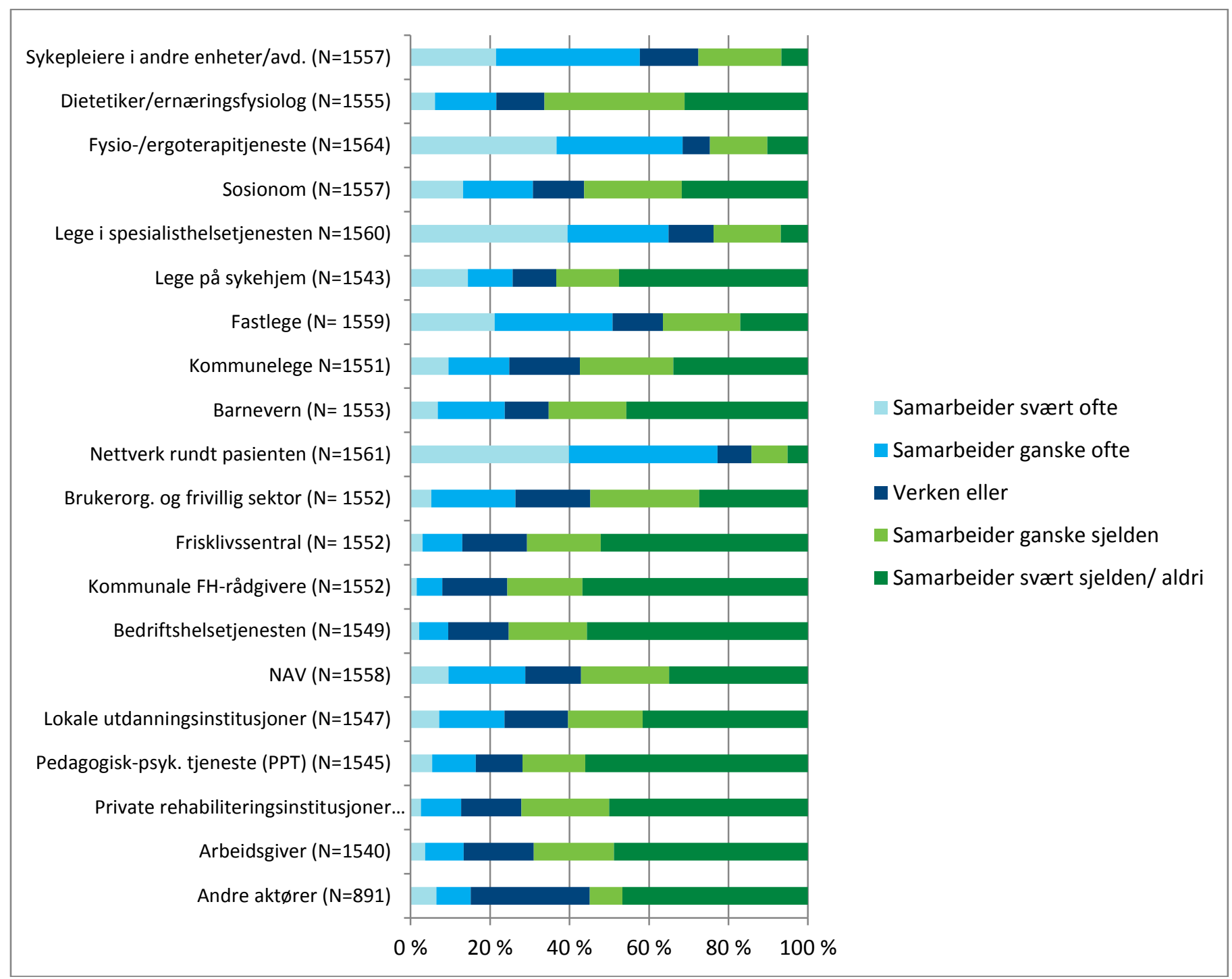

Figur 38 Hvor vanlig er det at din enhet/avdeling samarbeider med de følgende aktørene, som en del av det helsefremmende og forebyggende arbeidet? Prosent.

De aktørene sykepleierne i utvalget samarbeider mest med er nettverk rundt pasienten (pårørende og venner), lege i spesialisthelsetjenesten, fysio-/ergoterapitjeneste og sykepleiere $\mathrm{i}$ andre enheter/avdelinger. Nettverket rundt pasienten er den "aktøren" det samarbeides mest med; hele 39,9 prosent av utvalget sier at de samarbeider svært ofte med nettverket rundt pasienten, mens 37,4 prosent oppgir at dette er noe de gjør ganske ofte. Resultatet gir et klart bilde på hvor viktig pasientenes nettverk er for den oppfølgingen som gis innenfor helsevesenet, spesielt når det gjelder forebyggende og helsefremmende arbeid.

Fastlegen er også en aktør det er ganske vanlig å samarbeide med for sykepleierne i utvalget; 21,2 svarer at de samarbeider svært ofte med fastlegene, mens 29,6 prosent svarer at dette er noe de gjør ganske ofte. Fastlegene kan sies å representere førstelinjen i primærhelsetjenesten, gjennom å være den aktøren som pasientene først tar kontakt med. Fastlegene følger også pasientene over tid, og vil derfor spille en viktig rolle i folkehelsearbeidet. 


\section{(9) SINTEF}

Resultatene viser generelt at sykepleierne samarbeider mest med andre aktører innenfor helsefeltet. Det er mindre vanlig å ha kontakt med bedriftshelsetjeneste, lokale utdanningsinstitusjoner, private rehabiliteringsinstitusjoner og arbeidsgivere. Det ser ut til å være en del samarbeid når det gjelder NAV; om lag 29 prosent svarer at de samarbeider svært ofte eller ganske ofte med NAV. En forklaring på dette kan være at mange NAV-brukere, deriblant i gruppen med nedsatt arbeidsevne, så er det en stor andel som er under medisinsk behandling og i rehabilitering (se f.eks. Kalst $\varnothing$ \& Sutterud, 2015).

Et annet resultat som må kommenteres gjelder frisklivssentralene. De kommunale frisklivssentralene ble innført som en helsefremmende og forebyggende helsetjeneste, der målgruppen skulle være personer som har $\varnothing \mathrm{kt}$ risiko for - eller som har utviklet - sykdom, og trenger oppfølging av helsepersonell til å endre levevaner og mestre sykdom. ${ }^{4}$ Frisklivssentralene skal oppnå dette ved å tilby folk kunnskapsbasert og effektiv hjelp, der hovedmålet er endring i folks levevaner og deres evne til å mestre sykdom og helseplager. Ut fra denne beskrivelsen skulle en forvente at frisklivssentralene er en viktig samarbeidsakt $\varnothing r$ for de andre helsetjenestene når det gjelder folkehelsearbeid. Noe overraskende er det derfor å se at kun tre prosent av sykepleierne $i$ utvalget oppgir at de ofte samarbeider med frisklivssentralene, mens ti prosent svarer at det er en tjeneste de samarbeider ganske ofte med. 52 prosent svarer at det er en tjeneste de svært sjelden eller aldri samarbeider med. Det hører med til dette bildet at frisklivssentraler er et tilbud som ikke finnes i alle kommuner. Per i dag har om lag 210 kommuner etablert frisklivssentral, det vil si under halvparten av Norges kommuner. Dette kan være en forklaring på at samarbeidet mellom frisklivssentraler og sykepleiere i andre helsetjenester ikke er mer utbredt. En annen forklaring kan være at frisklivssentralene i for liten grad har markedsført seg inn mot kommune- og spesialisthelsetjenesten, noe som har gjort at samarbeidet ikke har kommet skikkelig i gang. Samtidig har Nasjonalt kunnskapssenter for helsetjenesten konkludert med at det er stor usikkerhet om tiltakene som frisklivssentralene tilbyr bidrar til bedret kosthold og $\varnothing \mathrm{kt}$ fysisk aktivitet over tid, etter den strukturerte veilednings- og oppfølgingsperioden $\mathrm{i}$ starten $^{5}$. Dette kan også være relevant for å forstå den beskjedne samhandlingen mellom ulike helsetjenester og frisklivssentralene.

I intervjuene snakket informantene mye om nødvendigheten av samarbeid innenfor det forebyggende og helsefremmende arbeidet. Vanlige utsagn var at det er helt essensielt å samarbeide med andre aktører for å få til et godt tilbud. Helsestasjon/skolehelsetjeneste beskriver seg selv som en generalisttjeneste, som skal gi et universelt tilbud til alle i målgruppen barn og unge i alderen 0-20 år og deres familier. Samtidig skal de henvise de som har behov for mer spesialiserte tjenester videre i systemet. Da er det behov for samarbeid både på det universelle og det spesialiserte området. En helsesøster trekker også fram at ved å samarbeide lærer man mye av andre:

"Jeg tenker det er lite man får gjort alene. Det er litt voksenopplæring i å se hva andre også gjør. Å se mulighetene. Når vi blir kjent med hva barnevernet gjør og hvordan innstilling de har til forebyggende arbeid, så lærer vi også noen ting. Og det samme med skolene: hvordan tenker skolene? Hvordan tenker barnehagene? Hvordan tenker våre samarbeidspartnere? Sånn at vi i det tverrfaglige samarbeidet blir mer kjent med hverandres ståsted" (Helsesøster, kommune 8)

\footnotetext{
${ }^{4}$ https://helsedirektoratet.no/folkehelse/frisklivssentraler (lesedato: 17.09.15)

5 http://www.kunnskapssenteret.no/nyheter/sunnere-atferd-med-frisklivssentraler (lesedato: 17.09.15)

PROSJEKTNR RAPPORTNR


Også innenfor spesialisthelsetjenesten er det viktig med samarbeid for å sikre at pasienten ivaretas på best mulig måte. Særlig ble det pekt på behovet for å kjenne til kommunens ulike tilbud og vite hvem man skulle henvende seg til for å samarbeide. Etter innføring av Samhandlingsreformen er det å skape et godt samarbeid med kommunen viktigere enn noen gang. Samarbeidet kunne ta ulike former, forklarte informantene. Ofte var det i form av samarbeidsmøter, men det kunne også være å arrangere et felles kurs, som sitatet under illustrerer:

"Jeg har samarbeidet en del med fylkeslegen, der vi blant annet har arrangert kurs for barn med kronisk forstoppelse og mageproblemer. Det er jo et folkehelseproblem. Det er mange barn som er rammet, og vi har jo en stor del av dem her" (Somatisk avd. sykehus)

Sykepleierne ble også spurt om hvilke av aktørene de mener det trengs et tettere samarbeid med, når målet er å jobbe bedre på det forebyggende og helsefremmende området. Neste figur viser hva de svarte.

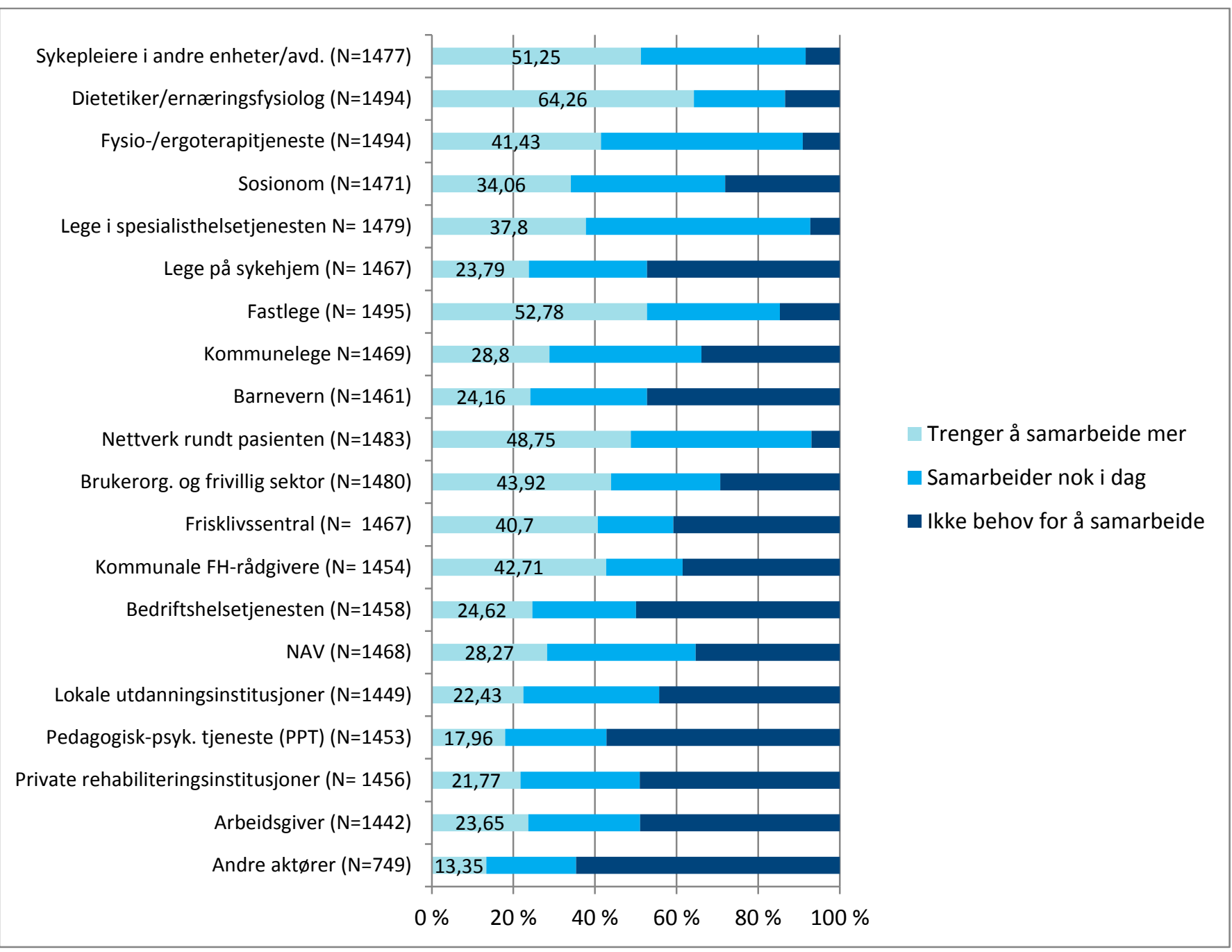

Figur 39 Hvilke av de samme aktørene mener du dere må samarbeide mer med? Prosent. 


\section{(9) SINTEF}

Fire aktører peker seg ut i sykepleiernes vurderinger av hvem de mener de trenger å samarbeide mer med, dersom de skal få til bedre forebyggende og helsefremmende arbeid; dietetiker/ernæringsfysiolog (64 prosent mener de trenger å samarbeide mer), fastlegene (53 prosent), sykepleiere i andre enheter/ avdelinger (51 prosent) og nettverk rundt pasienten (pårørende og venner) (49 prosent). Dietetiker/ ernæringsfysiolog er med andre ord den aktøren det ser ut til å være størst behov for å samarbeide mer med. Dette funnet gir også mening ut fra forrige figur, der vi så at dette er en aktør det samarbeides relativt lite med i dag (6,1 prosent samarbeider svært ofte og 15,4 prosent ganske ofte). Når vi vet at ernæring blir et stadig mer komplisert felt, er det naturlig at sykepleiere ønsker faglig veiledning på dette området, selv om kunnskap om ernæring er en del av sykepleiernes generalistkompetanse.

Det er interessant at en såpass stor andel mener at det trengs mer samarbeid med nettverket rundt pasienten, når vi i forrige figur så at dette er den aktøren det samarbeides mest med allerede. Videre mener 44 prosent at de trenger å samarbeide mer med brukerorganisasjoner og frivillige organisasjoner. Dette er positivt i et folkehelseperspektiv, i og med at denne typen organisasjoner vil kunne nå ut til andre mennesker enn det helsetjenestene gjør.

Ellers er det verdt å merke seg at bedriftshelsetjenesten og pedagogisk-psykologisk tjeneste (PPT) er to av de tjenestene som færrest mener det er behov for å samarbeide mer med. Dette er også to tjenester det samarbeides lite med $\mathrm{i}$ utgangspunktet, som vi så fra figuren foran. Bedriftshelsetjenesten er en tjeneste som kan spille en viktig rolle i folkehelsearbeidet, med arbeidsplassen som utgangspunkt. Når det gjelder PPT, så er det god grunn til å tro at det vil bli en stadig viktigere tjeneste, i takt med at omfanget av symptomdiagnoser og psykiske lidelser ser ut til å være økende (jf. Folkehelserapporten 2014).

I intervjuene kom informantene litt nærmere inn på forklaringer på hvorfor de jobber tettere sammen med noen aktører enn andre:

"Vi jobber mye med fysioterapeuter. De er jo en del av grunnbemanningen i helsestasjonen, selv om vi ikke er lokalisert sammen med dem. Og så har vi veldig mye å gjøre med psykologer. Hos oss er de lokalisert på helsestasjonen, så det har jo veldig mye å si for tilgjengeligheten og hvor godt kjent man blir, og hvor lav terskelen er for å ta kontakt med hverandre" (Helsesøster, kommune 6)

En hovedårsak til at det etableres et samarbeid er naturligvis at man har et behov for det. Som sitatet viser er imidlertid en faktor som samlokalisering avgjørende for tilgjengelighet til hverandre, hvor godt kjent man blir med hverandre, og dermed hvor enkelt det er å ta kontakt på tvers. Det finnes også utsagn som eksemplifiser årsaker til at man ikke tar kontakt, selv om man tenker at det kunne vært nyttig. Flere informanter trekker fram at barnevernet har et såpass dårlig rykte at de vegrer seg for å ta kontakt med dem. Det betyr ikke at sykepleierne selv tenker at ryktet er fortjent, men at de av hensyn til barnet og barnets pårørende synes det er vanskelig å ta kontakt med barnevernet. Dette er selvfølgelig uheldig, all den tid en fjerdedel av respondentene (og flere informanter) etterlyser mer samarbeid med barnevernet.

\subsection{Sosial ulikhet i helse}

Med sosial ulikhet i helse menes mer eller mindre systematiske forskjeller i helse (fysisk som psykisk) som kan knyttes til forskjeller i befolkningen når det gjelder utdanning, yrke, bo- og familiesituasjon, levevaner og folks generelle økonomiske situasjon. Norge er et land som kjennetegnes av betydelige sosiale forskjeller 


\section{(2) SINTEF}

i befolkningen. Ifølge Folkehelserapporten (2014) representerer de sosiale helseforskjellene et samfunnsproblem, fordi det innebærer at befolkningens samlede helsepotensial ikke blir realisert. Arbeidsdager og leveår preget av god helse og høy livskvalitet går tapt på grunn av sosialt betingede helseforskjeller. I hvilken grad opplever sykepleiere innenfor ulike deler av helse- og omsorgstjenesten at sosial ulikhet i helse er et tema som de er posisjonert til å gjøre noe med? For å finne ut mer om dette ble respondentene først spurt om i hvilken grad sosial ulikhet i helse er en utfordring i de pasientgruppene de jobber med. Svarene fordelte seg slik:

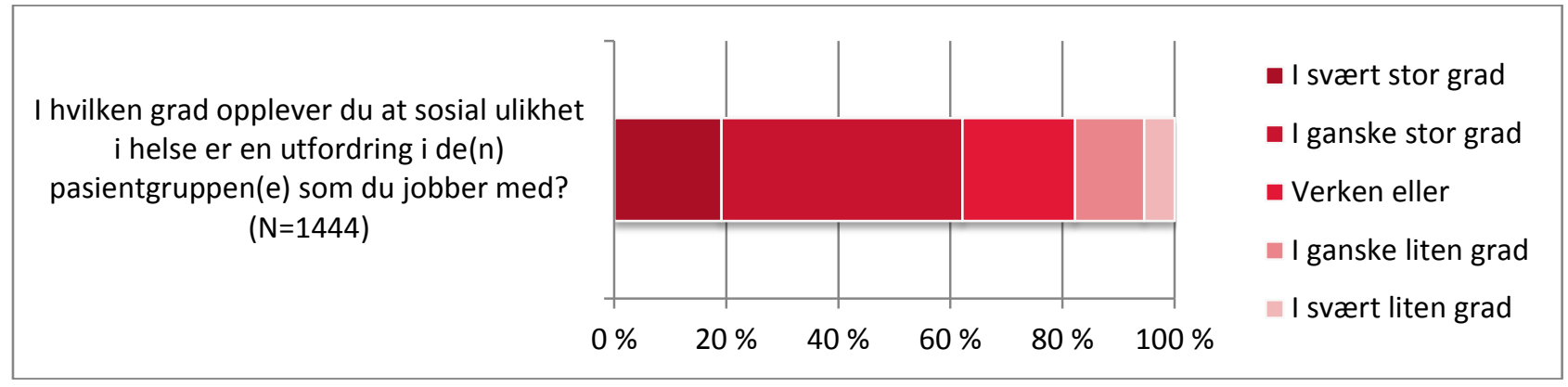

Figur 40 I hvilken grad opplever du at sosial ulikhet i helse er en utfordring i de(n) pasientgruppen(e) du jobber med? Prosent, hele utvalget.

Resultatene viser at sosial ulikhet $\mathrm{i}$ helse oppleves som en utfordring blant mange i utvalget. Over 60 prosent svarer bekreftende ( $\mathrm{i}$ svært stor grad eller $\mathrm{i}$ ganske stor grad) til påstanden om at sosial ulikhet $\mathrm{i}$ helse er en utfordring i sine pasientgrupper. Resultatet gir en påminnelse om hvor viktig det er å ha en helhetlig tilnærming til pasientene.

Blant sykepleierne som ble intervjuet i studien, var det først og fremst folkehelsekoordinatorene som snakket om sosial ulikhet i helse. Også helsesøstrene var inne på temaet, men det framsto ikke som like sentralt hos dem. En skal likevel ikke se bort fra at sosial ulikhet kan ligge under en del av utfordringene som helsesøstrene tok opp, for eksempel frafallsproblematikk på videregående skole. Folkehelsekoordinatorene fortalte at gjennom den pålagte kartleggingen av helsetilstanden blant befolkningen i kommunen, ble det mulig å sammenlikne egen kommune med andre og se hvordan en lå an for eksempel $\mathrm{i}$ forhold til barnefattigdom, antall arbeidsledige og sosialhjelpsmottakere. Dette vil være indikatorer på grupper som er utsatt for dårligere helse. Kartleggingen er således et nødvendig verktøy for å identifisere utsatte grupper, og den vil være første skritt $f \varnothing r$ en kan iverksette tiltak. Kartleggingen kan imidlertid oppleves som for overordnet $\mathrm{i}$ å avdekke sosial ulikhet, fordi den ikke fanger opp variasjon innad $\mathrm{i}$ kommunen. Én av koordinatorene sa:

"[Sosial ulikhet] er ikke synliggjort i kommunen. Og heller ikke gjennom oversiktsarbeidet, fordi der har man jo ikke brutt ned på den enkelte skolekrets. Jeg tror at hvis man hadde gjort det, hadde man funnet det - at det var i visse områder." (Folkehelsekoordinator, kommune 2)

Sosial ulikhet ble ikke opplevd som et direkte problem i alle kommunene vi gjorde intervjuer. Det har naturligvis sammenheng med at kommunene var svært forskjellige i størrelse og befolkningsgrunnlag. Likevel beskrev også disse kommunene utfordringer med for eksempel arbeidsledighet og manglende integrering av minoritetsgrupper. Slike utfordringer kan selvfølgelig også sees i sammenheng med sosial 
ulikhet, og koples mot helsetilstand. Oppsummert er det ganske komplekse årsaksforhold mellom sosial posisjon og helsetilstand, og ikke minst knyttet til hva slags tiltak en bør iverksette for å redusere sosial ulikhet. Denne rapporten handler hovedsakelig om hva (utøvende) sykepleiere kan gjøre i forhold til å redusere sosial ulikhet $\mathrm{i}$ helse, men koordinatorene gir eksempler på tiltak som ikke handler direkte om helse. Først skal vi imidlertid se på Figur 41 som viser sykepleiernes oppfatning av i hvilken grad de føler at de, gjennom helsefremmende og forebyggende arbeid, har mulighet til å redusere de samme sosiale helseforskjellene, målt gjennom tre ulike påstander.

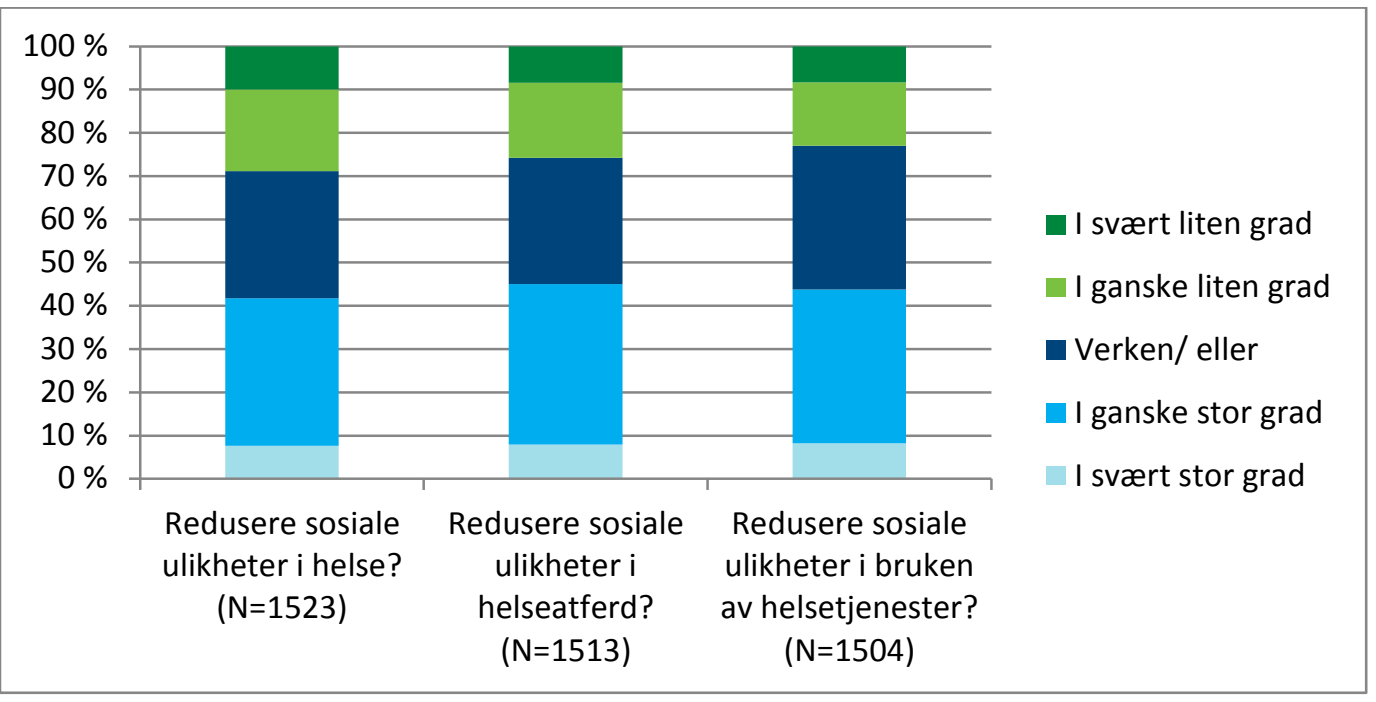

Figur 41 Muligheter til å redusere sosial ulikhet i helse? Prosent, hele utvalget.

Samlet sett ser vi at 40-45 prosent mener at de gjennom helsefremmende og forebyggende arbeid har mulighet til å redusere sosiale ulikheter i helse, helseatferd og i bruken av helsetjenester (i svært stor grad og i ganske stor grad). De fleste av disse svarer imidlertid med "i ganske stor grad". Når vi vet at sosiale ulikheter $\mathrm{i}$ helse springer ut av relativt tunge strukturer i samfunnet, så er det positivt at en såpass stor andel av sykepleierne gir uttrykk for at dette er noe de, gjennom sitt arbeid, mener at de har mulighet til å endre. Når vi i tillegg vet hvor nært knyttet folkehelse er til sosiale forskjeller i samfunnet, så er det positivt at sykepleierne opplever å være såpass i inngrep med disse utfordringene.

\subsection{Folkehelsekoordinatorenes erfaringer}

I denne siste resultatdelen presenterer vi funn fra intervjuene med folkehelsekoordinatorene. Vi har valgt å skille disse fra den $\varnothing$ vrige resultatpresentasjonen, siden folkehelsekoordinatorene har folkehelse som fulltidsarbeid og de heller ikke jobber klinisk. De representerer således et noe annet perspektiv på folkehelse enn de andre deltakerne i studien. $\mathrm{Ni}$ folkehelsekoordinatorer ble intervjuet. Stillingsandelen varierte fra 20 til 100 prosent. Alle var sykepleiere, og alle hadde en eller flere former for videreutdanning, eksempelvis psykiatrisk sykepleie og videreutdanning innen geriatri. I tillegg hadde noen gjennomført eller deltok i KS sitt kurs (masteremne) kalt "Helse og omsorg i plan." ${ }^{6}$ Felles for dem var at de gjennomgående var erfarne sykepleiere, noen hadde 20-30 års erfaring fra helsesektoren. Informantene hadde ulike titler

\footnotetext{
${ }^{6}$ http://www.ks.no/fagomrader/samfunn-og-demokrati/helse-og-omsorg-i-plan/ (lesedato: 24.08.15) 


\section{(9) SINTEF}

som "folkehelserådgiver", "folkehelsekoordinator" m.m., men i denne fremstillingen har vi for enkelhets skyld valgt å betegne alle som folkehelsekoordinatorer.

I intervjuene har folkehelsekoordinatorene snakket om sin kommunes utfordringer og hva slags folkehelsetiltak som er satt i gang i kommunen. De har beskrevet hvilke samarbeidspartnere som er involvert i det kommunale folkehelsearbeidet, og hvilke som i større grad burde vært involvert. Videre har de snakket om kommunepolitikernes oppmerksomhet og engasjement for folkehelse, inkludert hvordan rammebetingelsene for å drive folkehelsearbeid er. Alle har vært inne på spørsmålet om prioritering mellom forebyggende arbeid og behandling. Til sist har informantene reflektert rundt hvordan sykepleiekompetanse kan brukes i stillingen som folkehelsekoordinator, og generelt hvordan de opplever at sykepleiere er rustet til å drive med folkehelsearbeid. Selv om ni informanter ikke er et stort antall, viste intervjuene en stor bredde av utfordringer og tiltak i deres respektive kommuner. Intervjuene viste også ulikhet i hvor langt kommunene hadde kommet i folkehelsearbeidet. Noen hadde en lang tradisjon for å jobbe med folkehelse, mens andre først hadde satt i gang et slikt arbeid etter at Folkehelseloven trådte i kraft (1.1.12). De fleste mente uansett at ikrafttredelsen av Folkehelseloven fungerte som en katalysator for folkehelsearbeidet i kommunene. I avsnittet har vi valgt å trekke fram noen synspunkter og perspektiver fra koordinatorene som ikke målbæres på samme tydelige måte fra de andre informantene. Vi tror også at disse kan fungere som innspill til hva man bør vektlegge i det videre folkehelsearbeidet.

\section{Forståelsen av folkehelse og folkehelsearbeid}

Folkehelsekoordinatorene har en langt mer bevisst oppfatning av hva som regnes som folkehelsearbeid enn hva de andre informantene har. Dette er selvfølgelig ikke overraskende, gitt at stillingsinstruksen deres er å drive med folkehelsearbeid. Det er særlig noen poeng koordinatorene trekker fram når de reflekterer rundt hva folkehelsearbeid er. For det første er de opptatt av at det ikke bare er "helsearbeid." Flere av informantene mener at folkehelsearbeidet har en helseslagside, og én argumenterer for at "90 prosent av folkehelsearbeidet foregår $i$ andre sektorer enn i helsetjenesten". En annen sier at "ingen har monopol på folkehelsearbeidet". En informant peker på at helsepersonell må utvide sitt perspektiv på folkehelse:

"Det utvidede perspektivet på folkehelse... det er en øvelse, og det er noe som tar lang tid. (...) De som jobber i helsetjenesten, for eksempel helsestasjon og fastleger tenker mye at de vet hva folkehelsearbeid er. Men da er de fremdeles der [i folkehelsearbeidet] som helsetjenesten" (Folkehelsekoordinator, kommune 3)

En konsekvens av et slikt utvidet perspektiv på folkehelse, som uttrykkes av koordinatorene, innebærer at helsepersonell må vise ydmykhet $\mathrm{i}$ forhold til at også andre grupper har mye å bidra med $\mathrm{i}$ folkehelsearbeidet. Kanskje kan helsepersonell for eksempel bli (enda) flinkere til å invitere inn andre grupper i folkehelsearbeidet- samt bruke andre grupper som en ressurs inn i sitt eget arbeid. Det andre poenget, som må ses i sammenheng med den utvidede forståelsen av folkehelse og folkehelse som noe mer enn tradisjonelt "helsearbeid", er at folkehelsearbeidet som gjøres av koordinatorene i kommunene er strategisk arbeid på systemnivå, ikke på individnivå. Som en av koordinatorene sier:

"Folkehelsekoordinatoren er ikke en person som skal sørge for at alle innbyggerne jogger fem kilometer hver dag. Folkehelsekoordinatoren skal sørge for at folkehelsen blir ivaretatt $i$ planarbeidet $i$ kommunene" (Folkehelsekoordinator, kommune 4) 
Disse perspektivene speiles i rekken av folkehelsetiltak som koordinatorene beskriver at deres kommune har igangsatt. Tiltakene handler sjelden utelukkende om "helsetiltak", men om trafikksikkerhet, forbedring av kvaliteten på skole og barnehage, fysisk aktivitet som "Aktiv på dagtid", turløyper, kulturminnestier, å $\varnothing$ ke inkluderingen samt avhjelpe (barne)fattigdom. Koordinatorene selv jobber med planarbeid og administrativt arbeid. En slik forståelse av folkehelse legger også noen føringer for hvordan man skal arbeide. Vi går ikke i detalj inn på dette her, men går gjennom noen av de mest sentrale punktene.

Et annet punkt koordinatorene trakk fram er at folkehelsearbeid fra deres perspektiv handler om å jobbe med samfunnsutvikling og endring av samfunnsstruktur. Som en av informantene uttalte: "hvis du skal jobbe med det som er utfordringene innenfor levekår og sosiale forskjeller, så er det jo disse mer strukturelle forholdene." Det sier seg selv at endring av samfunnsstrukturer er et langsiktig arbeid, noe koordinatorene også er klar over. De peker på at de jobber ut i fra et langtidsperspektiv "og planlegger for mange år fram $i$ tid". Videre var koordinatorene vi intervjuet opptatt av at folkehelsearbeidet må være tverrfaglig og tverrsektorielt. Dette støttes også av studien som (Schou, Helgesen, \& Hofstad, 2014) har utført, om samhandlingsreformens effekt på kommunens helsefremmende og forebyggende arbeid.

Gjennom intervjuene ser vi at folkehelsekoordinatorer og sykepleiere som jobber utøvende i sektoren har noe ulike perspektiver på folkehelse. Dette er naturlig, gitt at koordinatorene og sykepleierne har ulike mandat for sitt arbeid. Begge kan likevel gjøre noe for å bedre folkehelsen på sitt felt. Det er dermed relevant å spørre hva helsetjenesten generelt kan lære av koordinatorene når det gjelder folkehelsearbeidet i kommunen, og hvordan dialogen mellom koordinatorene og praksisfeltet kan styrkes.

\section{Hvordan jobbe med folkehelse i tiden framover?}

Alle koordinatorene som ble intervjuet hadde sykepleierutdanning, og alle mente at sykepleiere er godt egnet til å jobbe med et forebyggende og helsefremmende perspektiv. Sykepleiere har blitt opplært til å se helheten framfor enkeltdeler av pasienten, og dette passer godt med folkehelseperspektivet. Som vi også så fra intervjuer med ansatte $\mathrm{i}$ hjemmesykepleien, påpeker imidlertid noen av koordinatorene at sykepleiere må bli flinkere til å la pasientene få større ansvar for eget liv:

"... det å få sykepleiere til å jobbe litt mer - som vi sier - med hendene på ryggen, eller å gjøre menneskene i stand til å leve livene sine, at de ikke skal gjøre det for dem. Jeg tror at det må man bare ha enda mere fokus på!" (Folkehelsekoordinator, kommune 5)

Ser vi videre på hva koordinatorene tenker er viktig i folkehelsearbeidet, så har vi oppsummert dette i fire punkter, med et tilhørende illustrerende sitat:

\section{- Folkehelsearbeid må bygges på tverrfaglig samarbeid}

Folkehelsearbeid er per definisjon et tverrfaglig, tverrsektorielt arbeid. En må derfor alliere seg med andre yrkesgrupper, og selvsagt frivillige og befolkningen, for å få til gode folkehelsetiltak:

"Jeg er jo bare en bit i et puslespill. Det er mange andre som jobber for det [folkehelse], men det er viktig at jeg har kunnskapen om at de jobber med det, og støtter opp om jobben deres og melder min interesse hvis det er naturlig" (Folkehelsekoordinator, kommune 2) 


\section{- Folkehelsekoordinatorene kan brukes som en ressurs}

Folkehelsekoordinatorene kan brukes som en ressurs for sykepleiere som ønsker å jobbe mer helsefremmende og forebyggende. Et eksempel på dette er at koordinatoren kan bistå de utøvende sykepleierne. I eksemplet under ba skolehelsetjenesten koordinator om å komme og orientere om kartleggingen av folkehelsa i kommunen:

"Vi snakket litt om utfordringsbildet og hva som ville være viktig for dem å satse på hvis de først skulle [sette i gang] noe, og da pekte jeg på tre områder, soner, i kommunen, som kanskje har spesielle utfordringer $i$ forhold til mange enslige forsørgere, i forhold til hvor viktig det er at de har et nettverk rundt seg, at de kanskje har litt leksehjelp." Så vi satt og snakket litt om det, og om hvor viktig det var da å se de barna" (Folkehelsekoordinator, kommune 2)

\section{- Folkehelsearbeid må ha et langtidsperspektiv - og det koster penger}

Folkehelsearbeid er et arbeid som tar tid, og som en ikke ser effekter av med en gang, påpeker mange informanter. Alle koordinatorene som ble intervjuet problematiserte ressurstilgangen i forhold til å holde på med folkehelse. For eksempel ble det nevnt at det lyses ut mange prosjektmidler fra Helsedirektoratet, men disse midlene går som oftest til høyrisikotiltak, det vil si tiltak rettet mot en utsatt gruppe der det allerede er identifisert et problem, typisk korttidstiltak. Det er vanskelig å få midler til universelle tiltak som først vil ha virkning om mange år. De universelle tiltakene må derfor vike for kortsiktig brannslukking:

"Folkehelsearbeid er et veldig langsiktig arbeid, og det koster. Det koster faktisk noe. I en overgangsfase nå, så tror jeg det er viktig å tilføre midler til folkehelsearbeidet - på et langsiktig plan" (Folkehelsekoordinator, kommune 3)

Et viktig forslag fra en koordinator er at kommunene kan hekte seg på nasjonale kampanjer, og utnytte det potensialet som ligger der. For små kommuner er det viktig drahjelp.

\section{- Ha et frisk-/ressursperspektiv heller enn et sykdomsperspektiv}

Avslutningsvis vil vi trekke fram et perspektiv som ble løftet fram av flere av informantene, nemlig å rette oppmerksomheten mot pasientens ressurser heller enn sykdom og problemer. Dette er kjernen $\mathrm{i}$ en helsefremmende tilnærming. Dette er også et perspektiv som helt sikkert kan få større utbredelse innenfor helse- og omsorgssektoren.

"Altså det er viktig å tenke at folkehelse, man jobber med påvirkningsperspektiv. Ikke med sykdomsperspektivet. Det er kjempeviktig, å tenke at vi skal påvirke for god helse. Og ikke ha fokus på sykdom" (Folkehelsekoordinator, kommune 4) 


\section{Oppsummering og diskusjon}

Målsetningen med prosjektet har vært å innhente kunnskap om sykepleieres kompetanse, erfaringer og oppfatninger av å drive med forebyggende og helsefremmende arbeid i det daglige. Vi har vært spesielt opptatt av å kartlegge rammevilkår på ulike nivåer, og hvordan disse styrker eller svekker mulighetene for å jobbe forebyggende og helsefremmende. I denne oppsummeringen ser vi først på sykepleiernes refleksjoner rundt folkehelsebegrepet, før vi drøfter nærmere de erfaringer og synspunkter som sykepleierne har delt med oss gjennom datainnsamlingen. Hvilke grupper sykepleiere utmerker seg i folkehelsearbeidet, og hva slags tiltak er det vanligst å iverksette? Og hvem er samarbeidspartnere for sykepleiere i dette arbeidet? Deretter oppsummerer vi det vi fant om sykepleiernes kompetanse på folkehelsearbeid, og drøfter hvordan den kan utnyttes bedre enn i dag. Dette punktet henger nært sammen med rammebetingelsene for folkehelsearbeid innenfor ulike deler av helse- og omsorgstjenesten. Etter dette drøfter vi kort sammenhengen mellom folkehelsearbeid og sosial ulikhet $\mathrm{i}$ helse, og sykepleiernes muligheter til å redusere sosial ulikhet i helse. Kapitlet avrundes med en drøfting av potensialet blant sykepleiere for å jobbe mer helsefremmende og forebyggende.

\section{Hva betyr folkehelsebegrepet for sykepleiere?}

Folkehelse er som tidligere nevnt et litt "vanskelig" begrep, fordi det oppleves å peke mot et systemperspektiv, der det er samfunnets innsats for å bedre befolkningens helsetilstand som regnes som folkehelse, og ikke det den enkelte sykepleier gjør i sitt daglige arbeid. Funnene i studien viser at en del ut $ø$ vende sykepleiere synes det er vanskelig å si at de jobber ut fra et folkehelseperspektiv. Nesten 30 prosent av sykepleierne i utvalget synes at helsefremmende arbeid som begrep er ullent og vanskelig å forholde seg til i sin daglige jobb, mens knapt 25 prosent synes forebyggende arbeid som begrep er krevende å forholde seg til i det daglige. Alt i alt gir tallene grunnlag for å hevde at kunnskapen om, og forståelsen av disse begrepene bør styrkes. Videre må det informeres tydeligere om hvordan disse perspektivene kan integreres og utøves innenfor ulike deler av helse- og omsorgstjenesten. Intervjuene bekreftet inntrykket av at folkehelse som begrep er krevende å forholde seg til, og mange sykepleiere er ikke fortrolige med begrepet. Likevel vil vi argumentere for at mange av sykepleierne vi intervjuet i praksis jobbet ut fra helsefremmende og forebyggende perspektiver; de brukte bare andre begreper på den tilnærmingen de har overfor pasientene. Dette kan tyde på at det er et behov for å konkretisere og operasjonalisere forebyggende og helsefremmende arbeid som begreper, slik at sykepleiere lettere kan se at det faktisk er en god del folkehelsearbeid i det de allerede gjør overfor pasientene.

\section{Hvilke grupper med sykepleiere er sentrale i folkehelsearbeidet?}

Ikke overraskende viser resultatene at helsestasjon og skolehelsetjenesten er den delen av helse- og omsorgstjenesten som jobber mest med helsefremmende og forebyggende arbeid. Helses $\varnothing$ strene innenfor helsestasjon og skolehelsetjenesten er den gruppen som i klart størst grad oppgir å bruke tid på helsefremmende og forebyggende arbeid. De skårer høyest på alle de innsatsområdene vi har kartlagt i rapporten. Dette er ikke overraskende, når vi vet at det er politisk bestemt og hjemlet i lov og forskrift at helsestasjon og skolehelsetjenesten skal være en av de mest sentrale aktørene i folkehelsearbeidet. I veilederen til forskrift om kommunenes helsefremmende og forebyggende arbeid i helsestasjons- og skolehelsetjenesten (Sosial- og helsedirektoratet, 2004) står det blant annet at disse tjenestene er sentrale i 


\section{(9) SINTEF}

kommunenes folkehelsearbeid. For at tjenestene skal fungere som forutsatt, er det viktig at kommunene sørger for at tilbudet er tilgjengelig for målgruppene, og at de ansatte har nødvendig kompetanse og ressurser. Helsestasjons- og skolehelsetjenesten skal være et tilbud som det er enkelt å opps $\varnothing$ ke, hvor man blir tatt på alvor med sine små og store helseproblemer og utfordringer. Forskriften skal sikre at helsestasjons- og skolehelsetjenesten bidrar til et helhetlig helsefremmende og forebyggende arbeid for barn og ungdom i alderen 0-20 år, og for gravide som går til kontroll ved helsestasjon.

At helses $\varnothing$ stre utmerker seg i positiv forstand i en unders $\varnothing$ kelse som omhandler folkehelsearbeid blant sykepleiere er derfor som forventet, tatt $\mathrm{i}$ betraktning tjenesteområdets mandat (helsefremmende og forebyggende tjenester for barn og unge). Dessuten er helsesøstrenes videreutdanning spesifikt rettet inn mot helsefremmende og forebyggende arbeid. Som NSF sier i sin brosjyre om helsesøstres spesialistgodkjenning: "Helsesøster er den eneste profesjonen som har en videreutdanning spesifikt rettet mot målgruppen barn og unge 0-20 år, i forhold til fagområdet helsefremmende og forebyggende arbeid, på arenaen helsestasjon og skolehelsetjenesten."

I samme veileder (Sosial- og helsedirektoratet, 2004) trekkes også psykisk helse frem som et viktig satsingsområde når det gjelder barn og unge. Det utdypes med at det "handler om å satse på styrking av psykisk helse, gjennom å legge til rette for opplevelser av mestring, god selvfølelse, menneskeverd, trygghet og respekt", og at kommunens helsefremmende og forebyggende arbeid i helsestasjoner og skolehelsetjeneste vil ha en viktig rolle når det gjelder psykisk helse. Resultatene i vår rapport kan tyde på at dette er noe som blir etterlevd i dag. Sykepleierne som jobber innenfor skolehelsetjenesten er den gruppen som i størst grad oppgir at de tar opp temaer som er viktig for barn og unges psykiske helse, slik som trivsel og sosial mestring (97,5 prosent svarer at dette er et tema som de svært ofte eller ganske ofte tar opp), ensomhet og isolasjon (81,5 prosent svarer det samme), nedstemthet (88 prosent), familie, venner og sosialt nettverk (98,5 prosent) og stress og stressmestring (82 prosent). Selv om dette ikke er medisinske diagnoser i seg selv, så er de symptomdiagnoser med høy prevalens i befolkningen (spesielt den unge delen av befolkningen), og de har betydning for utvikling av mer alvorlig psykisk sykdom på senere stadier.

Våre resultater viser at sykepleiere (helsesøstre) innenfor skolehelsetjenesten, som er den tjenesten som er definert som viktigst for folkehelsearbeidet $\mathrm{i}$ kommunene, i stor grad jobber på denne måten i praksis. Som en del av en forebyggende tjeneste er de opptatt av å jobbe helsefremmende og forebyggende overfor barn og unge. Det er ikke dermed sagt at rammebetingelsene de jobber under er optimale.

\section{De "tradisjonelle" folkehelsetemaene dominerer}

Bevegelse og fysisk aktivitet, hvile og $\varsigma \varnothing v n$ samt kosthold og ernæring er de tre temaene som prioriteres mest som en del av den oppfølgingen og dialogen sykepleierne har med sine pasienter. Samtidig finner vi at familie, venner og sosialt nettverk samt trivsel og sosial mestring også prioriteres i stor grad. Livsstil og livsstilsendring, alkoholbruk, tobakksbruk, økonomi, arbeid og utdanning er det mindre vanlig å bruke tid på som en del av pasientoppfølgingen. Når vi samtidig finner at 63 prosent av sykepleierne er av den klare oppfatning at det ofte er vel så viktig å rette oppmerksomheten mot den enkeltes ressurser, sosiale situasjon og livsstil, som sykdommen og den medisinske diagnosen, så er vi av den oppfatning at det i et 


\section{(9) SINTEF}

folkehelseperspektiv kan være mye å hente gjennom å fokusere på livsstil og livsstilsendring. Livsstil kan sies å være en "samlekategori", som i en eller annen grad berører mange av de andre folkehelseindikatorene, slik som kosthold, fysisk aktivitet, alkohol- og tobakksbruk, rusmiddelbruk samt døgnrytme og søvn. En helhetlig tilnærming, der man legger spesiell vekt på pasientenes livsstil, vil derfor kunne gi en stor folkehelsegevinst. En helhetlig forståelse av pasientenes situasjon krever imidlertid at sykepleierne har tid til å bli kjent med dem og deres utfordringer og behov.

\section{Egen kunnskap vurderes som god, men spørsmålet er om den tas godt nok i bruk}

Et flertall av utvalget mener at de har god kunnskap om folkehelsearbeid. Det er imidlertid viktig å skille mellom det å ha kunnskap om disse begrepene, og det å anvende dem i praksis. God "teoretisk kunnskap" hos den enkelte betyr ikke at man jobber på denne måten i praksis. Som denne rapporten viser, så er det en rekke ulike rammevilkår på ulike nivå som påvirker "rommet" for å jobbe helsefremmende og forebyggende. Når det gjelder kompetanse finner vi ellers at et flertall av sykepleierne, $i$ en eller annen grad, mener at de har for liten flerkulturell kompetanse i møte med pasienter fra andre kulturer. Når vi vet at folkehelseutfordringene er spesielt store i deler av innvandrerbefolkningen, så er dette et klart uttrykk for at folkehelse og innvandrerhelse er områder som må prioriteres sterkere, og som i enda større grad må ses i sammenheng.

Under halvparten av utvalget er enig (helt eller delvis) $\mathrm{i}$ at de lærte mye om helsefremmende og forebyggende arbeid gjennom sykepleierutdanningen. En stor andel ønsker seg flere kurs og mer opplæring knyttet til folkehelsearbeid på arbeidsplassen. Samtidig oppga et flertall at det meste de har lært om forebyggende og helsefremmende arbeid har de lært gjennom sitt eget arbeid. En viktig implikasjon er at uansett hvor mye helsefremmende og forebyggende arbeid som tas inn som tema i sykepleierutdanningen og i videreutdanning og spesialisering, så vil arbeidsplassen fortsatt representere en unik - og kanskje den viktigste - læringsarenaen. For at arbeidsplassen skal fungere som en slik læringsarena når det gjelder folkehelsearbeid, så er det imidlertid viktig at ledelsen er positiv og støttende, og legger til rette for å jobbe på denne måten.

\section{Folkehelseperspektivet som tema på arbeidsplassen}

Rammebetingelsene for å drive folkehelsearbeid bestemmes både nasjonalt, lokalt $\mathrm{i}$ kommunen og på den enkeltes arbeidsplass. I rapporten har vi fokusert mest på rammebetingelsene på arbeidsplassen. I spørreskjemaet har respondentene blant annet blitt spurt om hvorvidt deres ledelse har kommunisert tydelig at de skal jobbe helsefremmende og forebyggende. I overkant av 40 prosent var av en slik oppfatning. Videre svarte om lag 45 prosent at helsefremmende og forebyggende arbeid er tema som ofte diskuteres på arbeidsplassen. En like stor andel er av den oppfatning at de har organisert tjenestene/ tilbudet på en måte som legger til rette for å jobbe forebyggende og helsefremmende. Andelen som opplever at deres kompetanse på helsefremmende og forebyggende innsats utnyttes på en god måte, ligger noe lavere (42 prosent). Alt i alt viser resultatene at det er et potensial for å styrke fokuset på helsefremmende og forebyggende arbeid $i$ ulike deler av helse- og omsorgstjenesten. Unntaket fra dette ser ut til å være helsestasjons- og skolehelsetjenesten, som skårer svært høyt på alle våre spørsmål knyttet til mulighetene for å anvende forebyggende og helsefremmende metoder i det daglige. Dette er også som forventet. 


\section{(9) SINTEF}

\section{Helsefremming, forebygging og tiltak - hvilke varianter brukes?}

Tertiærforebygging (redusere følger for livskvalitet av sykdom og funksjonsnedsettelse) er den formen for forebygging som er mest vanlig å utøve blant sykepleierne i undersøkelsen, tett fulgt av sekundærforebygging (hindre tilbakefall eller forverring av sykdom og skade). En langt lavere andel av sykepleierne i utvalget oppgir at de jobber primærforebyggende (forhindre at skade og sykdom i det hele tatt oppstår). Samtidig må det tas høyde for at tjenestene er ulikt innrettet og har ulike formål og målgrupper. Resultatene tyder likevel på at det er et potensial for å styrke primærforebyggingen og det helsefremmende arbeidet.

Ser vi på hva slags tiltakstyper sykepleierne i studien oppga å anvende, viser resultater fra spørreundersøkelsen at under halvparten respondentene anvender universelle eller selektive tiltak - med unntak av helsestasjon/skolehelsetjeneste. Det er altså generelt sett vanligere å jobbe med tiltak som retter seg mot avgrensede grupper med kjent risiko (indikative tiltak) enn tiltak som retter seg mot alle (universelle tiltak). Mellom disse to finner vi de såkalte selektive tiltakene, som retter seg mot grupper som er i risiko. Tallene som viser bruken av indikative tiltak forsterker inntrykket av at det innenfor mange tjenester er tradisjon for å jobbe mer avgrenset, med målrettede tiltak mot grupper med kjent risiko. En åpenbar forklaring på dette er at mange tjenester retter seg mot pasientgrupper med kjent sykdom og sykdomsrisiko, og slik sett blir det urimelig å forvente at eksempelvis sykepleiere på en sengepost eller i et akuttmottak skal bruke mye tid på universelle tiltak. Helsestasjon og skolehelsetjeneste er den tjenesten som i klart størst grad jobber med universelle tiltak. Samtidig fremkommer det at dette er en tjeneste som lider under ressursmangel, og som tidvis må nedprioritere grupperettede og universelle tiltak på bekostning av individuelle tiltak og tiltak rettet mot mer avgrensede grupper.

Studien viser, særlig ser vi dette i funn fra intervjuene, at helse- og omsorgstjenestene er presset på ressurser slik at primærforebygging og universelle tiltak nedprioriteres til fordel for sekundær/tertiærforebygging og avgrensede tiltak. For å kunne jobbe mer universelt, og primærforebyggende må en jobbe for $\emptyset$ kte ressurser til tjenestene, og samtidig vurdere om en kan prioritere annerledes innenfor de rammene en har i dag. I tillegg må folkehelse bli et tydelig tema på ledernivå. Den enkelte sykepleier kan imidlertid gi sitt bidrag til at tematikken blir løftet frem, gjennom å peke på behovet for, og potensialet $i$, å satse mer på universelle tiltak.

Hvilke tiltak og hvilke former for forebygging sykepleierne anvender, kan trolig også ses i sammenheng med andre resultater i unders $\varnothing$ kelsen. Det at over halvparten av sykepleierne i utvalget sa seg helt eller delvis enig i påstanden om at det er en viktigere del av deres jobb å behandle/lindre sykdom enn å forebygge fremtidig sykdom, kan være relevant å trekke inn her. Dersom man er av den oppfatning at primæroppgaven er å lindre og behandle sykdom, vil det kunne begrense hvor bredt og helhetlig man tilnærmer seg pasientene. Samtidig er det et klart funn at tjenestetype, gjennom å sette klare rammer for tjenestens innhold og hvem målgruppen skal være, er en faktor som i stor grad definerer rammene for hvordan sykepleierne kan og skal jobbe. Dette gjelder også for det forebyggende og helsefremmende arbeidet. 
Så lenge sykepleiergjerningen for mange primært handler om å behandle, lindre og dempe negative konsekvenser av oppstått skade og sykdom, vil det kunne medføre noen begrensninger for hvor bredt og helhetlig sykepleierne tenker i møtet med pasientene. Samtidig må det presiseres at mange sykepleiere jobber forebyggende - selv om det ikke nødvendigvis er primærforebyggende. Resultatene viser at mange sykepleiere jobber for å avdekke og forebygge sykdomsrisiko, noe som er en viktig del av sykepleiefunksjonen (f.eks. forebygge trykksår og fall etc.). Det er derfor viktig å understreke at sykepleiere i stor grad har en forebyggende tilnærming innbakt i møtet med den enkelte pasient.

\section{God dialog med pasientene er en forutsetning for å jobbe helsefremmende og forebyggende}

Over 80 prosent av sykepleierne som har svart på spørreskjemaet mener at det er en viktig del av deres jobb å veilede pasientene $\mathrm{i}$ hvordan de kan leve mer helsevennlige liv. Om lag tre fjerdedeler av respondentene svarer at for å få til dette er det viktig å ha en god dialog med pasientene. Viktigheten av en ressursfokusert tilnærming til pasientene, heller enn en sykdomsfokusert tilnærming, understrekes også av følgende funn; 63 prosent av sykepleierne er av den klare oppfatning at det ofte er vel så viktig å rette oppmerksomheten mot den enkeltes ressurser, sosiale situasjon og livsstil, som sykdommen og den medisinske diagnosen. Videre bekreftet 72 prosent av sykepleierne i utvalget (helt enig) at de er avhengig av å ha en god dialog med pasientene for å kunne veilede dem om hvordan de skal leve helsevennlige liv.

Vi fant videre at de aktørene det samarbeides mest med blant sykepleierne i utvalget er nettverk rundt pasienten (pårørende og venner), lege i spesialisthelsetjenesten, fysio-/ergoterapitjeneste og sykepleiere i andre enheter/avdelinger. Resultatene viser dermed at sykepleierne samarbeider mye med andre aktører innenfor helsesektoren. Dette er et resultat som det er grunn til å dvele litt ved, når vi vet at så mye som 90 prosent av folkehelsearbeidet i samfunnet foregår utenfor helsesektoren. Dersom forventningen er at sykepleiere skal ha en viktig funksjon på folkehelseområdet i samfunnet generelt, så trengs det trolig et tettere samarbeid og en $\varnothing \mathrm{kt}$ koordinering mellom helsetjenesten og andre samfunnssektorer.

Når det gjelder sykepleiernes vurderinger av hvem de mener de trenger å samarbeide mer med, dersom de skal få til å jobbe mer forebyggende og helsefremmende, så pekte følgende fire aktører seg ut; dietetiker/ernæringsfysiolog, fastleger, sykepleiere $\mathrm{i}$ andre enheter/avdelinger og nettverket rundt pasienten. Det er interessant å merke seg at såpass mange ønsker mer samarbeid med dietetiker/ ernæringsfysiolog, når vi vet at ernæring er et sentralt tema for sykepleiere. Resultatet kan trolig forklares med at sykepleierne ikke opplever at de skal være eksperter på det som etter hvert har blitt et faglig krevende område (ernæringsfeltet), men heller inneha en generalistkompetanse. Sykepleierne vil derfor måtte spille på andre aktører og deres spisskompetanse på mange ulike områder, noe som understreker betydningen av samarbeid på tvers som en del av folkehelsearbeidet.

\section{Rammebetingelser for sykepleiernes folkehelsearbeid}

Resultatene viser at tjenestetype ser ut til å fungere som et "rammevilkår", som legger noen føringer for mulighetene til å jobbe ut fra et folkehelseperspektiv. Med tjenestetype tenker vi her på hvilken del av helse- og omsorgssektoren man jobber innenfor. Innenfor alle tjenester vil organisering, ansvarsdeling, grad av ledelsesforankring og -engasjement, men også hvilke arbeidsmetoder som anvendes, sette noen rammer for hva som er mulig å få til når det gjelder helsefremmende og forebyggende arbeid. Helsestasjon/skolehelsetjeneste er den tjenesten som skiller seg mest ut i positiv forstand, gjennom å yte 


\section{(9) SINTEF}

et tilbud innenfor alle de folkehelseområdene som vi har kartlagt i spørreundersøkelsen. Videre finner vi betydelige forskjeller når det gjelder innslaget av helsefremmende og forebyggende jobbing blant sykepleiere som jobber dagtid versus turnus. Forankring hos ledelsen, og det å ha folkehelsearbeid som et tema i møter, er eksempelvis langt vanligere på arbeidsplasser der en jobber dagtid. Sykepleiere som jobber dagtid jobber ofte i poliklinikker, og det er naturlig å tenke seg at det er større rom for helsefremmende og forebyggende arbeid der, enn på en sengepost, der arbeidsoppgavene er mindre forutsigbare.

Vi mener likevel at det vil være mer interessant og hensiktsmessig å se på betydningen av tjenestetype som rammevilkår, enn arbeidstidsordning. Mens arbeidstidsordning kan sies "å ligge fast", så vil det være mer å hente på å diskutere hvordan helsefremmende og forebyggende arbeid prioriteres innenfor ulike tjenester. Selv om tjenestene har ulike utgangspunkt basert på hvilke pasientgrupper de retter seg mot, samt hvilket tilbud de skal gi til pasientene, så mener vi likevel det kan være sunt å diskutere hvilken betydning kultur, "tradisjoner" og holdninger har for hvordan man tilnærmer seg pasientene på ulike arbeidsplasser, og for anvendelsen av en forebyggende og helsefremmende tilnærming. Gjennom en åpen diskusjon om disse temaene, vil man raskt kunne identifisere forbedringsområder.

Intervjuene med folkehelsekoordinatorene viste at Folkehelseloven har fungert som en katalysator for å få mer oppmerksomhet på folkehelsearbeidet i kommunene. Et økende antall kommuner har også kartlagt folkehelsa til befolkningen i kommunen (Riksrevisjonen, 2015; Schou et al., 2014). Både nasjonale, kommunale og lokale forhold på arbeidsplassen setter betingelser for folkehelsearbeidet. Organisering, ansvarsdeling, grad av ledelsesforankring og ledelsesengasjement, men også hvilke arbeidsmetoder som brukes ved den enkelte arbeidsplass, er faktorer som vil sette rammer for hva som er mulig å få til når det gjelder helsefremmende og forebyggende arbeid. Mens det på den ene side har vært en utvikling der helsestasjons- og skolehelsetjenesten får stadig flere oppgaver, så har vi også dannet oss et inntrykk av at helsefremmende og forebyggende arbeid ikke er godt nok forankret på ledernivå på mange arbeidsplasser. Dette må bli bedre dersom sykepleiere innenfor ulike deler av helse- og omsorgstjenesten skal bli en drivkraft i folkehelsearbeidet.

\section{Sosial ulikhet $\mathrm{i}$ helse er en utfordring sykepleierne kjenner på i det daglige}

Over 60 prosent av sykepleierne mener at sosial ulikhet i helse - i stor eller ganske stor grad - er en utfordring i deres pasientgruppe. Mellom 40-45 prosent mener at de, gjennom sin pasientoppfølging, har mulighet til å redusere sosial ulikhet i helse, sosiale ulikheter i helseatferd samt sosiale ulikheter i bruken av helsetjenester. Folkehelse er nært knyttet til sosiale ulikheter innen helse, og resultatet bekrefter slik sett sykepleiernes sentrale rolle innenfor folkehelsearbeidet. 


\section{(9) SINTEF}

\section{Konklusjon}

Samlet sett viser resultatene at det er et potensial blant sykepleiere for å jobbe mer forebyggende og helsefremmende. Dette uttrykkes både fra ledere, klinisk ut øvende sykepleiere og folkehelsekoordinatorer. Mange informanter peker for eksempel på at det bør utvikles lavterskeltilbud, for å få flest mulig av de som virkelig trenger det, tidlig inn i tjenesteapparatet. Det finnes allerede flere eksempler på slike tiltak i dag, men det er mulig å innrette flere tiltak på denne måten. Potensialet for å jobbe mer helsefremmende og forebyggende finnes både blant helsepersonell og pasienter. Det er derfor viktig å formidle til pasientene at det er sentralt for deres egen helse at de selv er mest mulig aktive og opplever mestring i egne liv. Som det fremkom av intervjuene med folkehelsekoordinatorene; mens sykepleierne må lære "å jobbe med hendende på ryggen", må pasientene få en økt forståelse av at det er viktig for deres egen helse at de selv er mest mulig aktive (jf. den store satsningen på hverdagsrehabilitering vi ser i dag).

Sykepleiere har alltid vært engasjert i folkehelsearbeid i betydningen forebyggende og helsefremmende arbeid. Det er også en del av utdanningen, noe som bekreftes i denne rapporten. Samtidig viser rapporten at mange sykepleiere opplever å være presset på tid og ressurser, og derfor må bedrive "brannslukking" fremfor å jobbe forebyggende og helsefremmende. Det er en bevissthet og en vilje blant sykepleierne til å jobbe ut fra et folkehelseperspektiv, men det trengs enda større oppmerksomhet om folkehelse innenfor ulike deler av helse- og omsorgstjenesten. Videre trengs det en styrking av kompetansen, særlig knyttet til flerkulturell kompetanse og det å se bredden og totaliteten i folkehelseperspektivet (det handler om langt mer enn sykdom og fysisk helse).

Innledningsvis i rapporten pekte vi på at folkehelse er et stort og omfattende begrep, som er vanskelig å avgrense. Spesielt i lys av de definisjoner av folkehelsearbeid som ble presentert tidlig i rapporten, der folkehelsearbeid i stor grad betraktes som den samlede "helseinnsatsen" i samfunnet utenfor operasjonsstuer, poliklinikker, sengeposter og sykehjem. Vi må også ta høyde for at sykepleierne i undersøkelsen har ulike oppfatninger av hva folkehelsearbeid er. Avhengig av hvilke tjenester de jobber innenfor og hvilke pasientgrupper de jobber inn mot, så vil sykepleiernes forståelse av folkehelsearbeid kunne variere mellom tjenester, samt avvike fra de offisielle definisjonene. Forståelsen av folkehelsearbeid formes med andre ord av den konteksten man jobber innenfor, og dette er det viktig å huske på når sykepleiere blir bedt om å svare på ulike spørsmål knyttet til folkehelsearbeid. Dette er også grunnen til at vi har vært mer opptatt av å foreta en åpen kartlegging av statusen for folkehelsearbeidet der ute, enn å fastslå i hvilken grad det som gjøres, er innenfor rammene av myndighetenes definisjon av folkehelsearbeid. 


\section{(9) SINTEF}

\section{Referanser}

Folkehelseinstituttet. (2014). Folkehelserapporten 2014. Helsetilstanden i Norge. Rapport 2014: 4. Oslo: Folkehelseinstituttet.

Helse- og omsorgsdepartementet. (1999). Lov om spesialisthelsetjenesten m.m. (spesialisthelsetjenesteloven) LOV-1999-07-02-61. Oslo: Helse- og omsorgsdepartmentet.

Helse- og omsorgsdepartementet. (2011a). Lov om folkehelsearbeid (folkehelseloven) LOV-2011-06-24-29. Oslo: Helse- og omsorgsdepartementet.

Helse- og omsorgsdepartementet. (2011b). Lov om kommunale helse- og omsorgstjenester m.m. (helse- og omsorgstjenesteloven) LOV-2011-06-24-30. Oslo: Helse- og omsorgsdepartementet.

Helse- og omsorgsdepartementet. (2013). Meld. St. 34 (2012-2013) Folkehelsemeldingen. God helse - felles ansvar. Oslo: Helse- og omsorgsdepartementet.

Helse- og omsorgsdepartementet. (2015). Meld. St. 19 (2014-2015) Folkehelsemeldingen. Mestring og muligheter. Oslo: Helse- og omsorgsdepartementet.

Helsetilsynet. (2015). Med blikk for betre folkehelse. Oppsummering av landsomfattande tilsyn i 2014 med arbeidet i kommunane med løpande oversikt over helstilstanden til befolkninga og påverknadsfaktorer etter folkhelselova. Oslo: Statens helsetilsyn.

Kalstø, Åshild M og Lars Sutterud (2015) Personer med nedsatt arbeidsevne og mottakere av arbeidsavklaringspenger, juni 2015. Notat. Arbeids- og velferdsdirektoratet, Statistikkseksjonen

Lai, L. (2004). Strategisk kompetansestyring. Bergen: Fagbokforlaget.

Olufsen, V., Sliper, J. O., \& Aune, I. (2015). Kartlegging av ledelse i skolehelsetjenesten i Sør-Trøndelag. Trondheim: Fylkesmannen i Sør-Trøndelag.

Riksrevisjonen. (2015). Riksrevisjonens undersøkelse av offentlig folkehelsearbeid. Dokument 3.11 (20142015). Oslo: Riksrevisjonen.

Schou, A., Helgesen, M. K., \& Hofstad, H. (2014). Samhandlingsreformens effekt på kommunen som helsefremmende og sykdomsforebyggende aktør. NIBR-rapport 2014: 21. Oslo: NIBR.

Sosial- og helsedirektoratet. (2004). Kommunenes helsefremmende og forebyggende arbeid i helsestasjon og skolehelsetjenesten. Veileder til forskrift av 3.april 2003 nr. 450. Rapport IS-1154. Oslo: Sosial- og helsedirektoratet.

Åkerstedt, T. (2003). Shift work and disturbed sleep/wakefulness. Occupational Medicine, 53(2), 89-94. 
(2) SINTEF

Vedlegg 


\section{(9) SINTEF}

\section{Vedlegg 1}

Figurene 6 - 11 i kapittel 4 presenterte hvordan de følgende temaene var en del av den oppfølgingen og dialogen som sykepleierne har med sine pasienter (fordelt på tjenestetype); bevegelse og fysisk aktivitet; kosthold og ernæring; trivsel og sosial mestring; alkoholbruk og annen rusbruk; familie, venner og sosialt nettverk; livsstil og livsstilsendring. Figurene i vedlegg 1 viser tilsvarende tabeller, men nå for de andre folkehelseindikatorene.

Spørsmål: Hvor vanlig er det at de følgende temaene er en del av den oppfølgingen og dialogen som du har med dine pasienter?

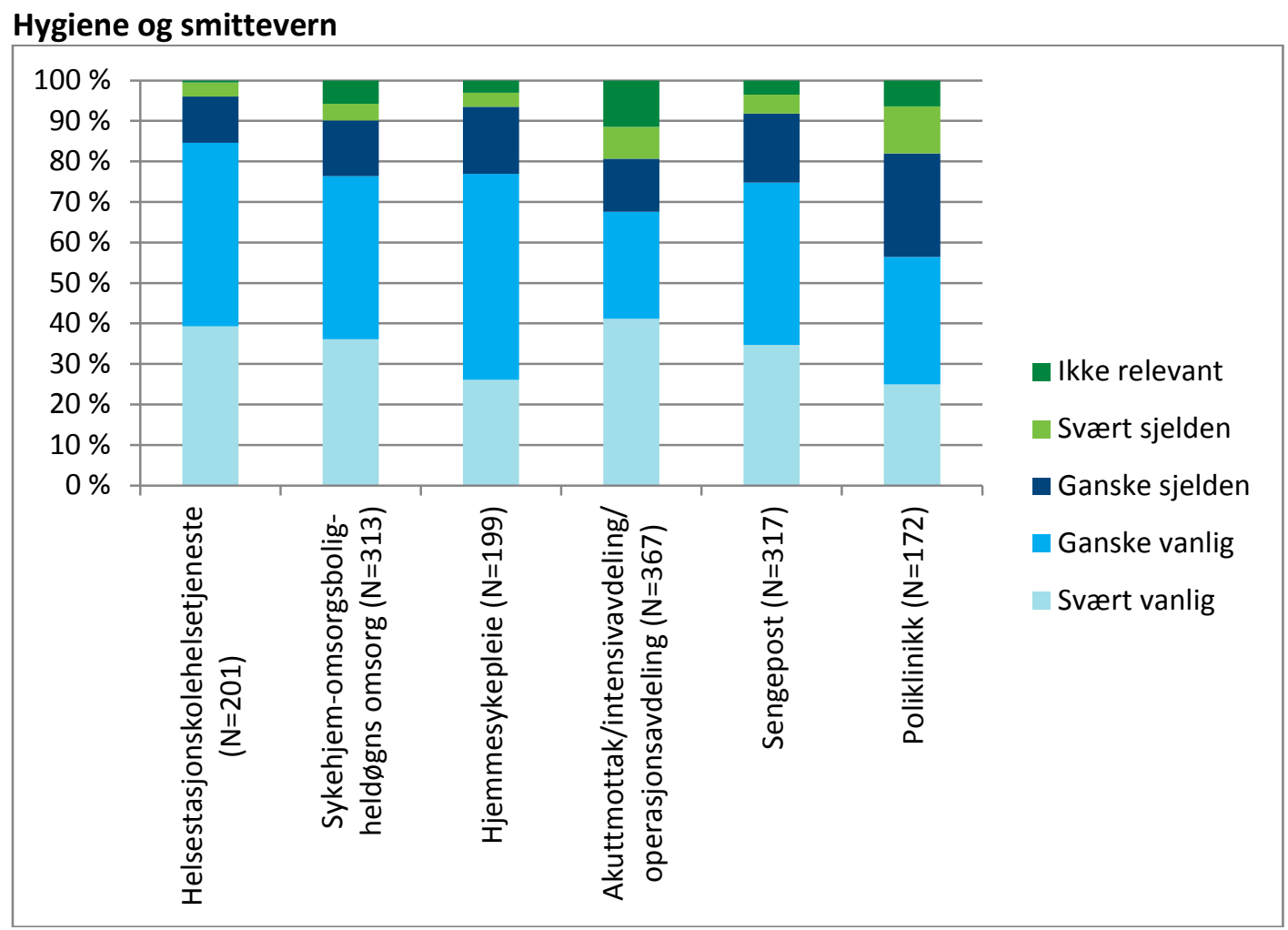




\section{(9) SINTEF}

\section{Hvile og søvn}

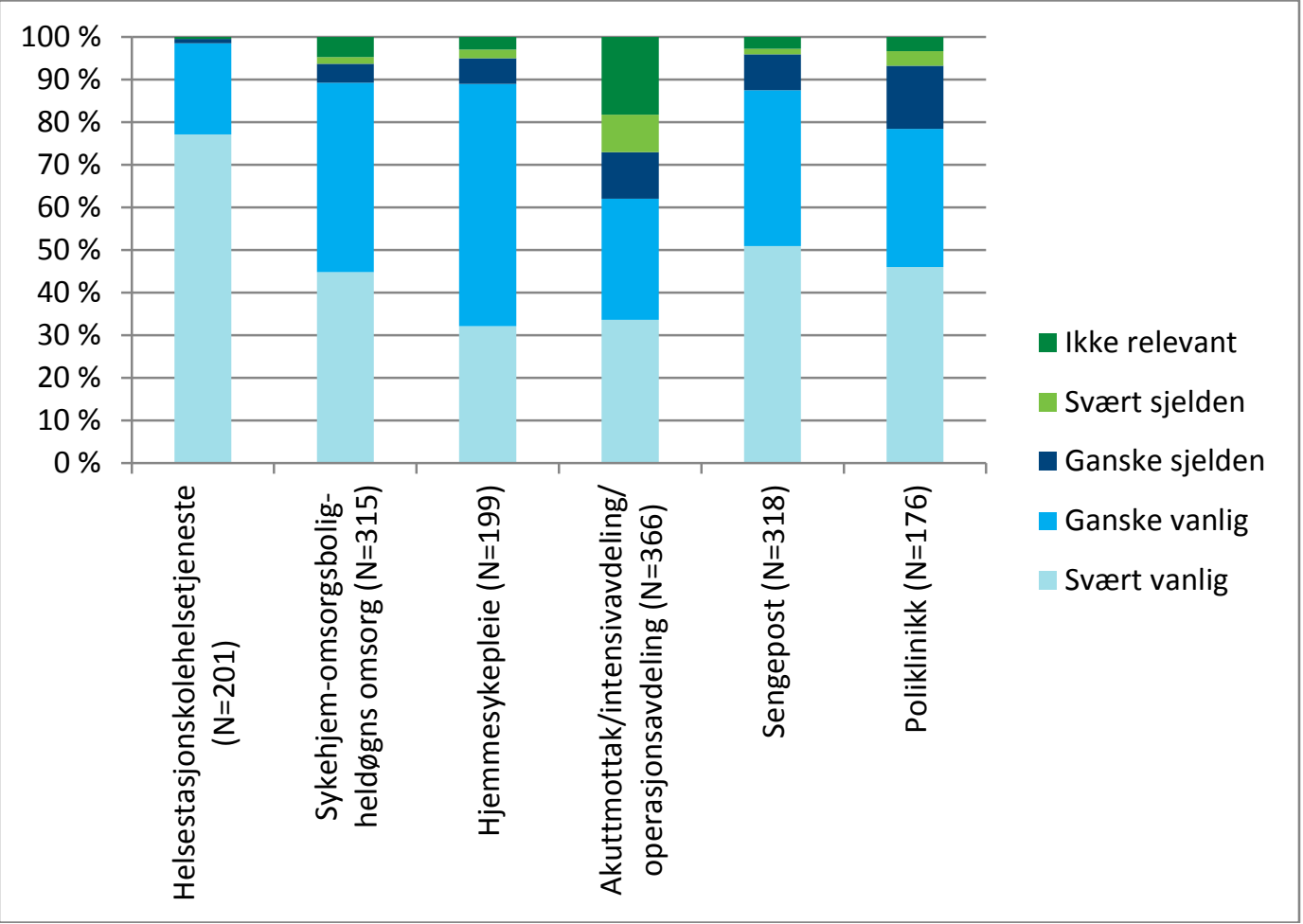

\section{Ensomhet og isolasjon}

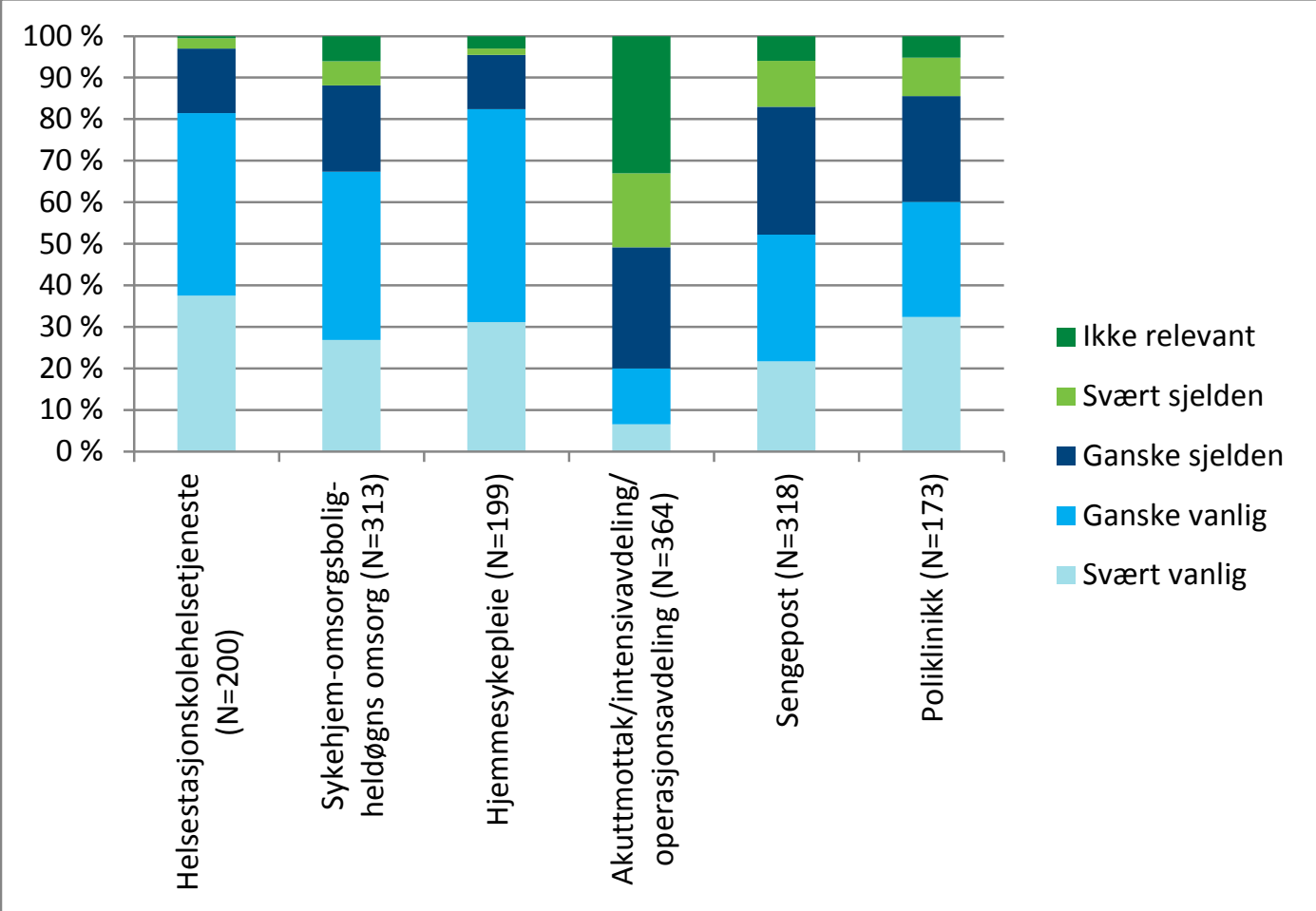




\section{(9) SINTEF}

Nedstemthet

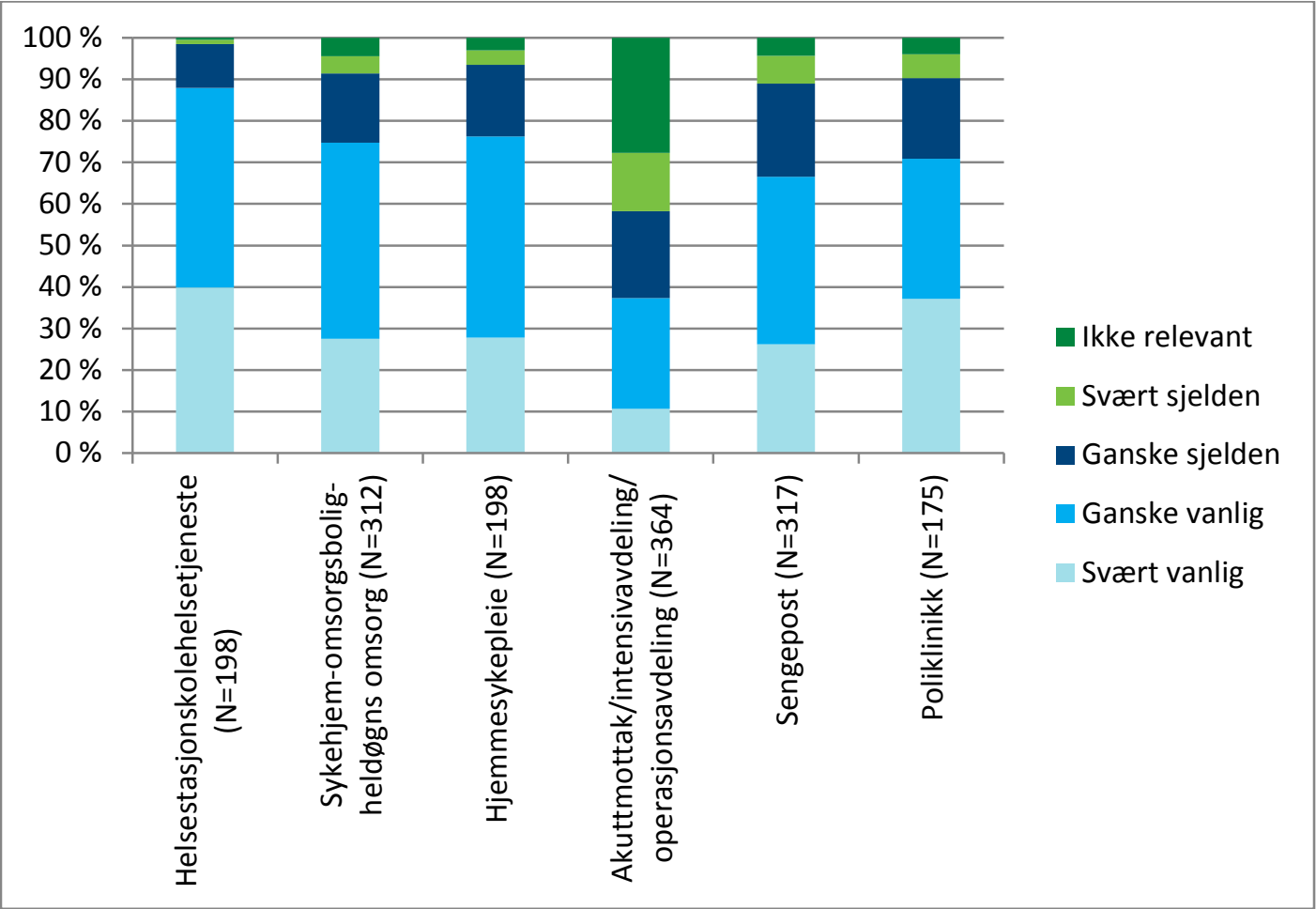

Tobakksbruk

\begin{tabular}{|c|c|c|c|c|c|c|c|}
\hline \multicolumn{8}{|l|}{$100 \%$} \\
\hline \multicolumn{8}{|l|}{$90 \%$} \\
\hline \multicolumn{8}{|l|}{$80 \%$} \\
\hline \multicolumn{8}{|c|}{$70 \%$} \\
\hline \multicolumn{8}{|l|}{$60 \%$} \\
\hline \multicolumn{8}{|c|}{$\begin{array}{l}50 \% \\
40 \%\end{array}$} \\
\hline \multicolumn{8}{|l|}{$40 \%$} \\
\hline \multirow{2}{*}{\multicolumn{8}{|c|}{ 口 Ikke relevant }} \\
\hline & & & & & & & Svært sjelden \\
\hline $10 \%$ & & & & & & & \\
\hline 070 & 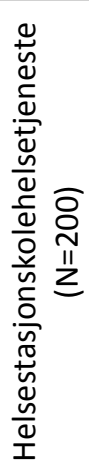 & 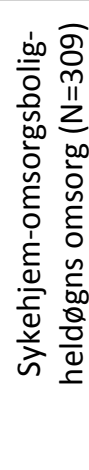 & 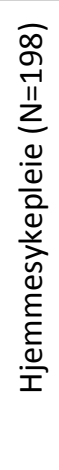 & 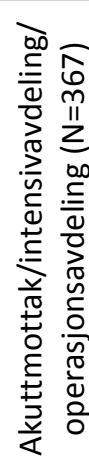 & 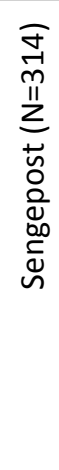 & 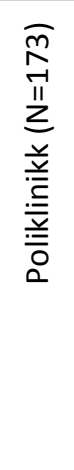 & Ganske vanlig \\
\hline
\end{tabular}




\section{(2) SINTEF}

\section{Seksuell helse}

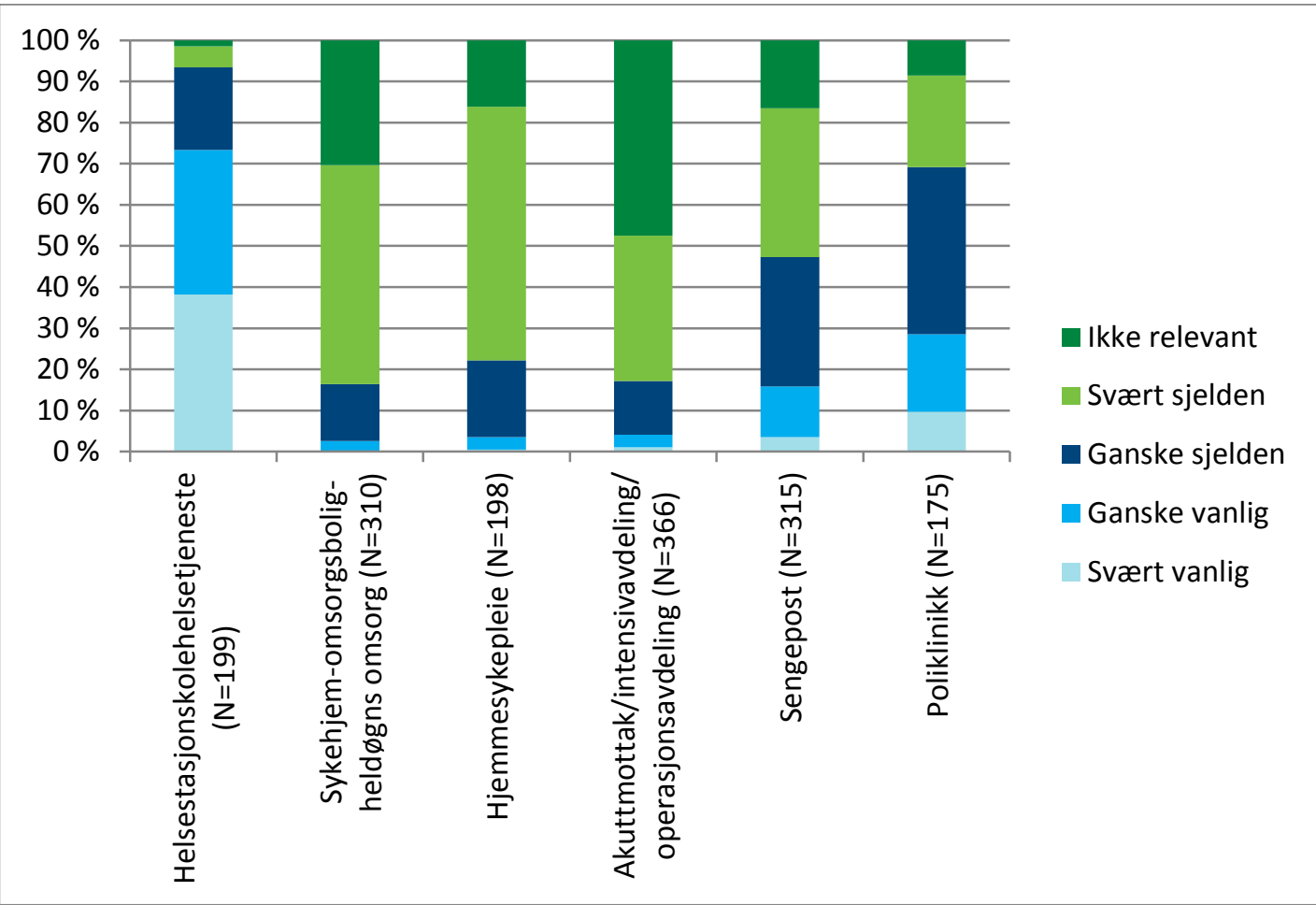

\section{Stress og stressmestring}

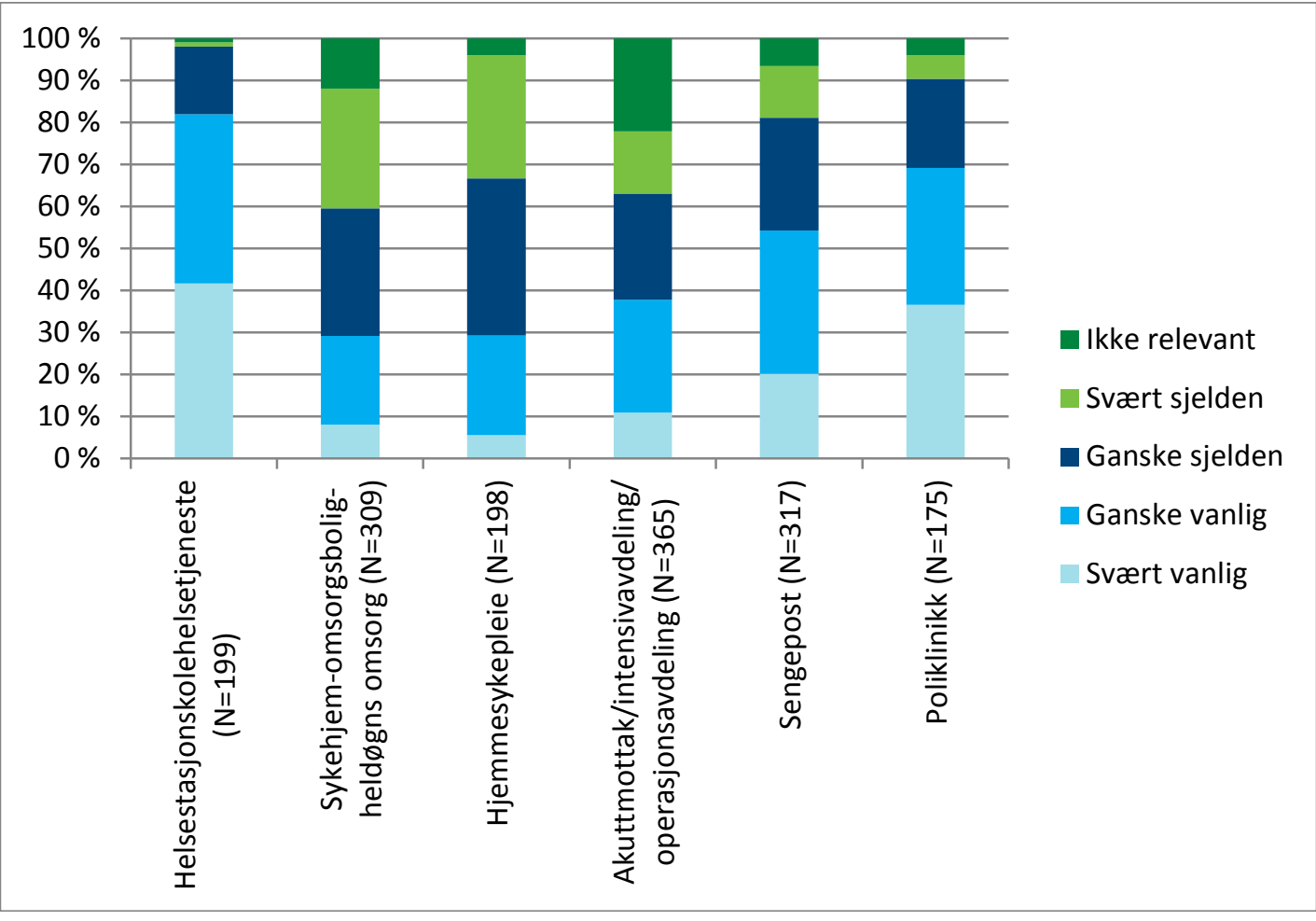




\section{(2) SINTEF}

\section{$\varnothing$ konomi og boligsituasjon}

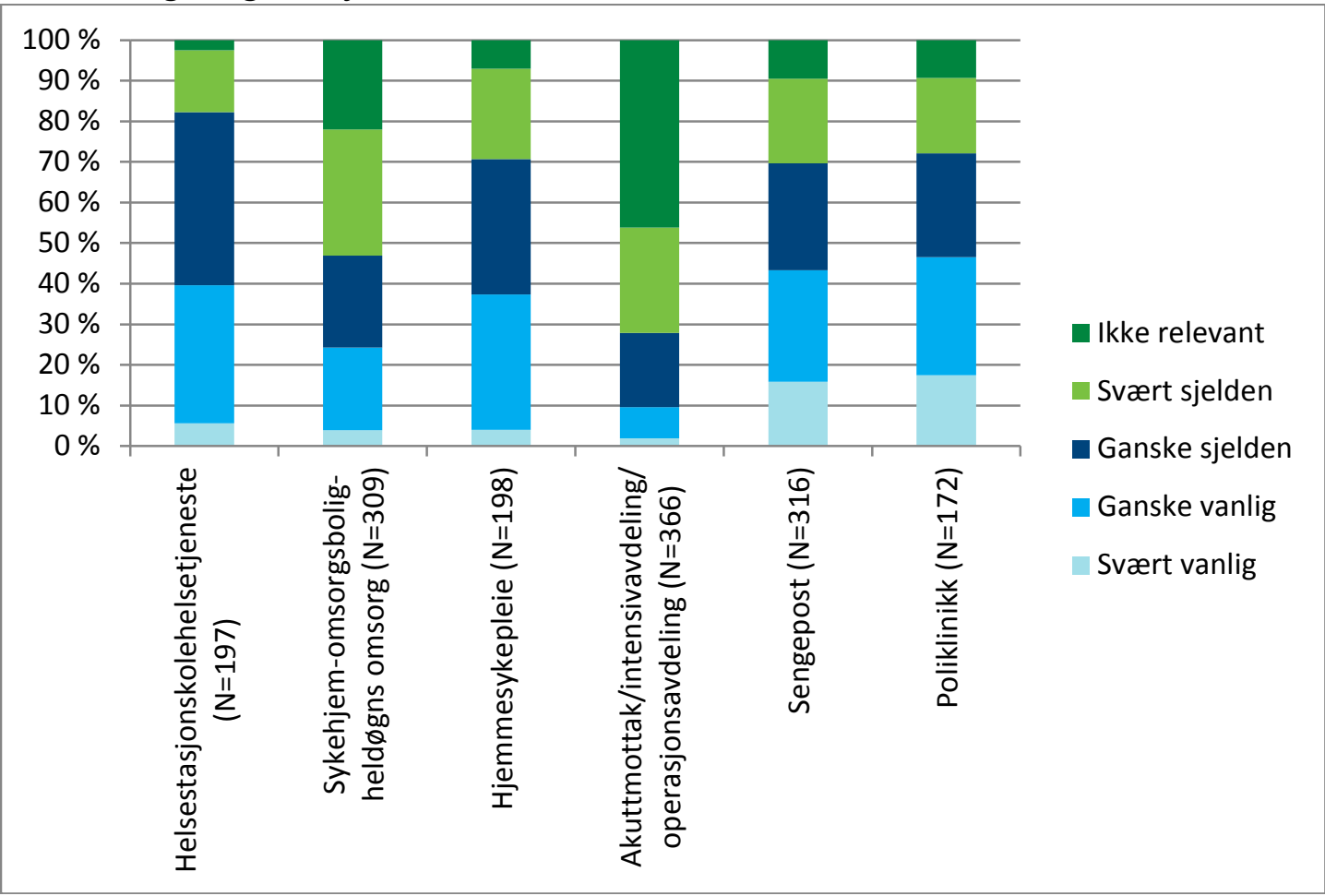

\section{Skole/utdanning}

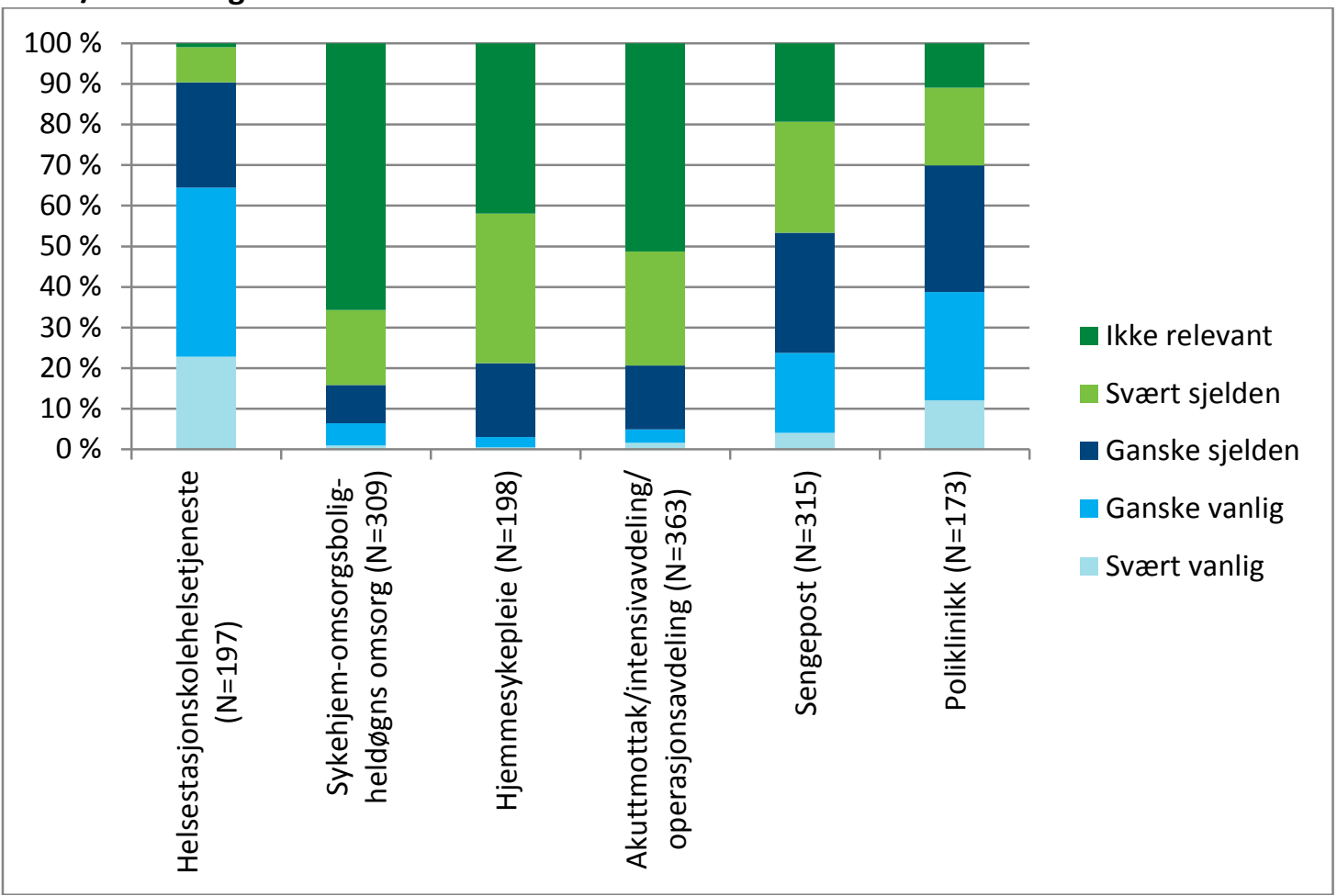




\section{(9) SINTEF}

\section{Arbeid og yrkesvalg}

\begin{tabular}{|c|c|c|c|c|c|c|c|}
\hline \\
\hline \multicolumn{8}{|l|}{$\begin{array}{r}00 \% \\
90 \%\end{array}$} \\
\hline $80 \%$ & & & & & & & \\
\hline $70 \%$ & & & & & & & \\
\hline $60 \%$ & & & & & & & \\
\hline $50 \%$ & & & & & & & \\
\hline $40 \%$ & & & & & & & \\
\hline $30 \%$ & & & & & & & Ikke relevant \\
\hline $20 \%$ & & & & & & & Svært sjelden \\
\hline $10 \%$ & & & & 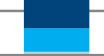 & & & ovart seticit \\
\hline 070 & 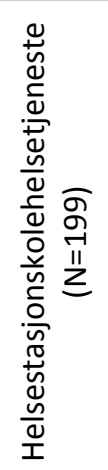 & 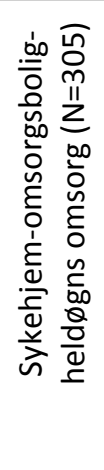 & 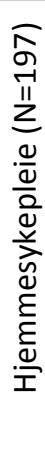 & 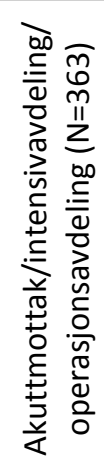 & 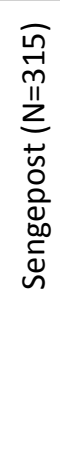 & 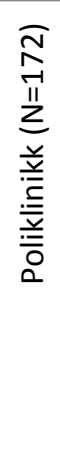 & Ganske vanlig \\
\hline
\end{tabular}




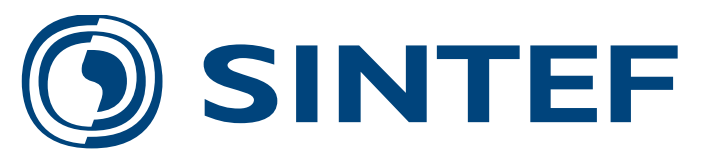

Teknologi for et bedre samfunn www.sintef.no 